\title{
Performance implications of manufacturer-retailer power battles
}

Citation for published version (APA):

Hermans, M. (2017). Performance implications of manufacturer-retailer power battles. [Doctoral Thesis, Maastricht University]. Universitaire Pers Maastricht. https://doi.org/10.26481/dis.20170216mh

Document status and date:

Published: 01/01/2017

DOI:

10.26481/dis.20170216mh

Document Version:

Publisher's PDF, also known as Version of record

\section{Please check the document version of this publication:}

- A submitted manuscript is the version of the article upon submission and before peer-review. There can be important differences between the submitted version and the official published version of record.

People interested in the research are advised to contact the author for the final version of the publication, or visit the DOI to the publisher's website.

- The final author version and the galley proof are versions of the publication after peer review.

- The final published version features the final layout of the paper including the volume, issue and page numbers.

Link to publication

\footnotetext{
General rights rights.

- You may freely distribute the URL identifying the publication in the public portal. please follow below link for the End User Agreement:

www.umlib.nl/taverne-license

Take down policy

If you believe that this document breaches copyright please contact us at:

repository@maastrichtuniversity.nl

providing details and we will investigate your claim.
}

Copyright and moral rights for the publications made accessible in the public portal are retained by the authors and/or other copyright owners and it is a condition of accessing publications that users recognise and abide by the legal requirements associated with these

- Users may download and print one copy of any publication from the public portal for the purpose of private study or research.

- You may not further distribute the material or use it for any profit-making activity or commercial gain

If the publication is distributed under the terms of Article $25 \mathrm{fa}$ of the Dutch Copyright Act, indicated by the "Taverne" license above, 


\section{PERFORMANCE IMPLICATIONS OF MANUFACTURER-RETAILER POWER BATTLES}

Marleen Hermans 
C Copyright Marleen Hermans, Maastricht 2017

All rights reserved. No part of this publication may be reprinted or utilized in any form or by any electronic, mechanical or other means, now known, or hereafter invented, including photocopying and recording, or in any information storage or retrieval system, without permission from the copyright owner.

ISBN 9789461596659

Universitaire Pers Maastricht

Cover Background: adapted from Bewalrus/Freepik

Cover Font: Open Sans by Steve Matteson

Cover Design: Vera Bossel

Layout and Printing by: Datawyse 


\title{
Performance Implications of Manufacturer-Retailer Power Battles
}

\author{
DISSERTATION \\ to obtain the degree of Doctor at Maastricht University, \\ on the authority of the Rector Magnificus, Prof. dr. Rianne M. Letschert, \\ in accordance with the decision of the Board of Deans, to be defended in public on \\ Thursday, February 16, 2017, at 12.00 hours \\ by \\ Marleen Hermans
}




\section{Supervisor}

Prof. Dr. Ko de Ruyter

\section{Co-Supervisors}

Dr. Kathleen Cleeren (KU Leuven, Belgium)

Dr. Néomie Raassens (TU Eindhoven, The Netherlands)

\section{Assessment Committee}

Prof. Dr. Joost Pennings (Chair)

Prof. Dr. Marnik Dekimpe (Tilburg University, The Netherlands)

Dr. Bram Foubert

Dr. Katrijn Gielens (UNC Kenan-Flagler Business School, United States) 
Acknowledgements 
The last four years have been an incredibly challenging and exciting journey. After working in business for almost two years, an e-mail arrived from Maastricht University with an invitation to discuss a possible Ph.D. trajectory. This invitation has significantly altered my career as I decided to leave the business world behind me and pursue an academic career. To this day, I am very happy with my decision, and thankful to be given this opportunity. The result of this exciting journey is this dissertation. I would like to take the opportunity to thank all of you who contributed to the dissertation, and who supported and encouraged me to achieve this accomplishment.

First, I would like to thank my promotor, Prof. Dr. Ko de Ruyter. Ko, thank you for being my promotor. Your guidance, support in my decisions, and positive encouragements are highly appreciated. I also highly appreciate the freedom you gave me in the development of the projects, which allowed me to pursue the topics of my interest.

Further, I would like to express my gratitude for my co-promotors, Dr. Kathleen Cleeren and Dr. Néomie Raassens. I value your comments and suggestions very highly, and I am grateful that you always took time for me even when your schedules were very busy. Thank you for sharing your knowledge and for the unconditional support. Kathleen, your e-mail almost five (!) years ago was the kick-off to my Ph.D. adventure in Maastricht. Your effort, eagerness to progress, and critical questions helped me to push myself, and lift my research to a higher level. I am still astonished and thankful for your incredibly fast replies to my many e-mails; it always helped me to get back on track. Néomie, thank you for being there for me whenever I needed advice. You were always available and took time to discuss concerns or problems that I faced, both research and non-research related. I consider myself lucky to have the two of you as my co-promotors, and I am looking forward to our further fruitful collaboration.

In addition, I would like to express my gratitude to the other members of my assessment committee: Prof. Dr. Joost Pennings, Prof. Dr. Marnik Dekimpe, Dr. Bram Foubert, and Dr. Katrijn Gielens. I feel very privileged and honoured to have such distinguished academics in my committee. Thank you for your valuable suggestions and comments that have certainly improved this dissertation. Your feedback is truly appreciated.

I also want to thank AiMark for providing the unique household panel data that enabled me to carry out my first project (Chapter 2). In particular, I would like to thank Bernadette van Ewijk for her help in enabling access to the data and for her support with the interpretation of the data.

Over the years I have attended various academic conferences, seminars, and workshops. My gratitude goes out to all the people that I met at these academic conferences and that made these a memorable experience. I hope we have many more in the future!

My gratitude goes to all my colleagues at the Marketing and Supply Chain Management Department at Maastricht University. First, I would like to thank our secretaries, Eefje and Pascalle for their assistance in the administrative tasks. I would 
also like to thank all the other department members for the research discussions, nice talks, and lunchbreaks.

I would especially like to thank all the Ph.D. candidates in the department for the interesting Ph.D. activities, parties, and coffee breaks. Thank you for sharing both the highlights and frustrations of the Ph.D. process with me. Stefania and Francisco, my fellow rookies! Thank you for the dinners and Ph.D. academy parties. In the last years, I had the pleasure of having many officemates. Hannes, Nadine, Vera, Ile, Anika, Teerawut, Kars, Tim (and Anja), I really enjoyed sharing an office with you. Anika, we still need to go salsa dancing! I would also like to thank Aline, Christine, Judith, Flo, Lennart, Martina, and Wiebke and for all the fun times, coffee breaks, and legendary social activities! Christoph and Anant, I really enjoyed our pub quizzes. Also big thanks to Alex, Ben, Kimberley, Leticia, Liz, Luuk, Piet, Pieter, Robert, Ruud, Susan, and Theo.

I would like to extend my gratitude to Vera and Ile, my paranymphs. Vera, thanks for lifting my spirit and for always reminding me to have fun! I will cherish our interesting discussions, beauty tips, and, especially, the many popcorn moments! Ile, it is rare to find a friend with the same geeky humor! Thank for sometimes distracting me from the PhD by means of our coffee and tea breaks, and walks with Hemi! You are wonderful friends and I am delighted to have you as paranymphs.

Also a big thank you to all my friends from 'back home'. In particular I would like to thank "De Wieve" - Valerie, Kelly, Florien, and Ellen - who I have known for such a long time, and who I can always count on. Even if we haven't seen each other for a while, we are always able to pick up where we left. Whether we have dinner, go dancing, have drinks, see a movie, or go shopping; all of my academic worries magically disappear. Special thanks to Valerie, your motivational skills are highly appreciated!

Last, but not least, I would like to thank my family for their support. Lisa (en Bert), bedankt voor jullie steun, begrip, en gezelligheid! Lisa, ik kan me geen beter zusje wensen. Pap en mam, bedankt voor jullie onvoorwaardelijke steun en advies. Pap, bedankt voor de waardevolle praktische tips en suggesties, en uiteraard de support bij het maken van beslissingen. Mam, bedankt voor het luisteren naar mijn verhalen, vieren van de goede momenten en steun in mijn frustraties. Ik had niet zonder jullie gekund. Bedankt veur alles! 



\section{Contents}

Acknowledgements

List of figures $\quad$ xi

List of tables $\quad$ xii

Chapter 1 Introduction $\quad 1$

1.1 Conflict Delistings $\quad 4$

1.2 Gaps in the Literature $\quad 4$

1.3 Contributions of this Dissertation $\quad 7$

1.4 Objectives and Structure 8

1.5 Outline of Dissertation 9

Chapter 2 The Effectiveness of Managerial Actions during Conflict Delistings $\quad 11$

2.1 Introduction 13

2.2 Conceptual framework $\quad 15$

2.3 Model $\quad 22$

2.4 Data 25

2.5 Results $\quad 31$

2.6 Robustness Checks 36

$\begin{array}{ll}2.7 \text { Discussion } & 37\end{array}$

Chapter 3 The Market Valuation of Conflict Delistings $\quad 43$

3.1 Introduction 45

3.2 Performance Implications Of Coercive Power: A Literature Overview 47

3.3 Conceptual Framework $\quad 48$

3.4 Event Study Methodology 55

3.5 Empirical Study 58

$\begin{array}{lll}3.6 & \text { Results } & 61\end{array}$

3.7 Robustness Checks 63

3.8 Discussion 65

$\begin{array}{ll}\text { Chapter } 4 \text { Conclusion } & 71\end{array}$

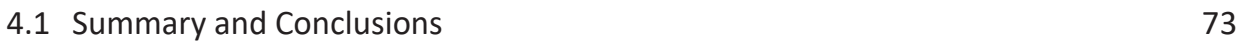

$\begin{array}{lll}4.2 & \text { Practical Implications } & 75\end{array}$

$\begin{array}{lll}4.3 & \text { Future Research } & 76\end{array}$ 
References

Appendix

Valorization

Chapter 2: The Effectiveness of Managerial Actions during Conflict Delistings

Chapter 3: The Market Valuation of Conflict Delistings

Summary

Curriculum Vitae

101 


\section{List of figures}

Chapter 2 The Effectiveness of Managerial Actions during Conflict Delistings Figure 2.1: Heider's Balance Theory 17

Figure 2.2: Conceptual Framework

Chapter 3 The Market Valuation of Conflict Delistings

Figure 3.1: Conceptual Framework 


\section{List of tables}

Chapter 1: Introduction

Table 1.1: Overview Conflict Delistings: Comparison to Other Product Unavailability Types

Table 1.2: General Overview of Dissertation

Chapter 2 The Effectiveness of Managerial Actions during Conflict Delistings

Table 2.1: Operationalizations and Data Sources of IVs

Table 2.2: Variable Definitions and Summary Statistics

Table 2.3: Correlation Matrix Brand-Sales Model

Table 2.4: Correlation Matrix Category-Sales Model

Table 2.5: Empirical Results for the Brand-Sales Model

Table 2.6: Empirical Results for the Category-Sales Model

Table 2.7: Marketing Dashboard: How to Respond to Conflict Delistings

\section{Chapter 3 The Market Valuation of Conflict Delistings}

Table 3.1: Market Indices

Table 3.2: Explanatory Variables and Data Sources

Table 3.3: Descriptive Statistics and Correlation Matrix

Table 3.4: CAARs for Different Event Windows

Table 3.5: Empirical Results

Table 3.6: Predicted CARs as a Function of the Seriousness of the Delisting and Capacity to Withstand Negative Consequences ${ }^{(a)}$ 
Chapter

Introduction 

"When Greek meets Greek, then comes the tug of war"

- $\quad$ Proverb, based on play by Nathaniel Lee 1766

The recent shift in power in the retailing landscape has grasped the attention of many academics and practitioners (Ailawadi et al. 2010). Traditionally, manufacturers have dominated the retailing landscape, providing them an attractive bargaining position and the upper hand in manufacturer-retailer negotiations. Their large size was in stark contrast to the fragmented and often local retailers, allowing them to impose their prices and other buying conditions on these typically small retailers (Ailawadi, Borin and Farris 1995; Van der Maelen, Breugelmans, and Cleeren 2017). More recently, the rise of private label brands (Ailawadi 2001; Draganska, Klapper, and Villas-Boas 2010), the availability of advanced consumer information such as scanner data (Chu and Messinger 1998), scarcity of shelf space (Ailawadi, Borin, and Farris 1995), passthrough of trade promotions (Ailawadi et al. 2010), and the creation of large retailer agglomerations (Aalto-Setälä 2002; Dawar and Stornelli 2012; Messinger and Narasimhan 1995) have tilted this power balance, leading to manufacturer-retailer relationships in which both parties are very powerful.

This shift in power balance posits managerial challenges for both parties. While manufacturers were able to pressure retailers into complying in 'the good old days', they nowadays face a strong and solid counterparty. On the one hand, manufacturers depend on retailers as they make the final decision which brands to carry in their assortment (Dukes, Geylani, and Srinivasan 2009), while on the other hand, the introduction of private labels transformed retailers into direct competitors for the manufacturers' national brands. In a similar vein, the stronger bargaining position allows retailers to fight back to the once almighty manufacturers. The relationship with manufacturers is complex for retailers as well, as retailers depend on manufacturers' often popular national brands to generate store traffic (Shankar, Carpenter, and Farley 2012), while at the same time, the intense competitiveness of the current retailing landscape obliges retailers to keep the prices of the national brands at an unprecedented low in order to survive (The Telegraph 2016).

All in all, the relational dynamics between manufacturers and retailers are complex, and while it is yet unclear who exactly has the power in the retailing landscape, the two parties are a good match for each other. This is reflected in the struggling negotiations between the two parties, which, due to their frequently conflicting objectives, often go sour. In an attempt to pressure the opponent to comply with its demands, both the manufacturer and retailer often (threaten to) delist products from the shelves until the conflict is resolved. This phenomenon is referred to as conflict delistings. 


\subsection{CONFLICT DELISTINGS}

Conflict delistings are defined as a temporary delisting of products due to a conflict (Van der Maelen, Breugelmans, and Cleeren 2017). Conflict delistings occur frequently in the current retailing landscape. To exemplify, discounter Lidl delisted all Coca-Cola, Fanta, and Sprite soft drinks from their shelves in a price conflict (Die Welt 2014). In a similar vein, Dutch manufacturer Aviko ceased the delivery of their products to retailer Jumbo, after Jumbo did not comply with their increased prices (Distrifood 2016). Other examples of conflict delistings include the delisting of Mattel's Disney dolls by toy store Fun (De Standaard 2011), and the delisting of paint brand Alpina by Do-It-Yourself (DIY) store Obi (Lebensmittelzeitung 2005). Conflict delistings can include a wide variety of products, ranging from a single SKU or variety to a delisting of multiple brands. As illustrated by above examples, both manufacturers and retailers can initiate a conflict delisting. Indeed, the manufacturer can decide to cease the delivery of their products to the retailer, while the retailer can opt to remove manufacturers' brands from the shelf. However, this strategy can have a major (financial) impact for a company. For instance, Premier Foods announced that a conflict delisting by Tesco cost them $£ 10$ million (The Grocer 2011a).

Firms may have numerous reasons to engage in conflict delistings, however, the majority of conflict delistings are due to price negotiations gone sour. This could involve both disagreements about wholesale prices and disagreements about consumer prices. While Britvic withheld supply of Pepsi to Sainsbury's after the retailer refused the demands for a significant increase in wholesale prices (The Grocer 2011b), Dutch manufacturer Peijnenburg ceased the delivery of their popular 600 gram breakfast cake to retailer Albert Heijn when the retailer would not increase the consumer price of the product (Distrifood 2005a). Also other buying conditions, such as shelf space allocation or promotional support, could lead to conflict delistings. In addition, several retailers initiated conflict delistings when a manufacturer decided to offer steep price promotions for their product at a competing retailer, often a discounter. To exemplify, German retailer group Metro delisted confectionary brands Toffifee and Merci from manufacturer Stock in response to a price reduction of Toffifee at discounter Aldi (Lebensmittelzeitung 2004).

\subsection{GAPS IN THE LITERATURE}

Based on an extensive literature review, three prominent gaps regarding conflict delistings can be identified. 


\subsubsection{Gap \#1: Performance Implications of Conflict Delistings}

Despite the inherent managerial importance, research on the performance implications of conflict delistings is still scarce. An important exception is a study by Van der Maelen, Breugelmans, and Cleeren (2017), who investigated consumer reactions to conflict delistings using one specific conflict case. They find that, in that particular conflict case, both the manufacturer and retailer suffered severe market share losses due to the conflict delisting. However, it is currently unclear whether their findings can be generalized to other delisting situations. Due to the lack of literature, I will therefore consider a related literature stream: product unavailability.

An inherent characteristic of conflict delistings is the unavailability of products at a retailer. In this light, conflict delistings may be similar to other product unavailability types, such as assortment reductions, out-of-stock occurrences (OOS), product harm crises, and brand delistings (e.g., Borle et al. 2005; Emmelhainz et al. 1991; Sloot and Verhoef 2008; Van Heerde, Helsen, and Dekimpe 2007). However, findings from these studies cannot directly be transferred to a conflict delisting context, due to important differences between the various unavailability types. Table 1.1 provides an overview and comparison of conflict delistings to other product unavailability types. Most noteworthy is the underlying cause of the unavailability. In the case of conflict delistings, products are deliberately unavailable due to a manufacturer-retailer conflict. This arguably has important implications for amongst others, consumer decision making, due to the strong attribution of blame. Indeed, consumers do not only respond to the delisting, but also to the conflict itself. Nevertheless, given the scarce literature on conflict delistings, we depend on the product unavailability literature to provide some valuable insights. From the studies on OOS occurrences, product harm crises, and brand delistings, there is an indication that product unavailability might be harmful for both manufacturers and retailers. In contrast, the assortment reduction literature provides ambiguous results, with some studies reporting negative (Borle et al. 2005) and others reporting no (Broniarczyk, Hoyer, and McAlister 1998) or positive consequences (Drèze, Hoch, and Purk 1994). 
Table 1.1: Overview Conflict Delistings: Comparison to Other Product Unavailability Types

\begin{tabular}{|c|c|c|c|c|c|}
\hline & $\begin{array}{l}\text { Cause of } \\
\text { unavailability }\end{array}$ & $\begin{array}{l}\text { Deliberate } \\
\text { action }\end{array}$ & Time span & Affected products & $\begin{array}{l}\text { Scope of } \\
\text { unavailability }\end{array}$ \\
\hline $\begin{array}{l}\text { Assortment } \\
\text { reduction }\end{array}$ & $\begin{array}{l}\text { Increase } \\
\text { operational } \\
\text { efficiency }\end{array}$ & Yes & $\begin{array}{l}\text { Long-term } \\
\text { (permanent) }\end{array}$ & $\begin{array}{l}\text { SKU, predominantly } \\
\text { low equity products }\end{array}$ & $\begin{array}{l}\text { All stores of one } \\
\text { retail chain }\end{array}$ \\
\hline $\begin{array}{l}\text { Out-of-Stock } \\
\text { (OOS) }\end{array}$ & $\begin{array}{l}\text { Issues with } \\
\text { delivery }\end{array}$ & No & $\begin{array}{l}\text { Short-term } \\
\text { (typically few } \\
\text { days) }\end{array}$ & $\begin{array}{l}\text { Brand/SKU, could be } \\
\text { either high- or low } \\
\text { equity products }\end{array}$ & $\begin{array}{l}\text { Typically one } \\
\text { isolated store }\end{array}$ \\
\hline $\begin{array}{l}\text { Product-harm } \\
\text { crises }\end{array}$ & $\begin{array}{l}\text { Product } \\
\text { malfunction }\end{array}$ & No & $\begin{array}{l}\text { Long-term } \\
\text { (typically few } \\
\text { months) }\end{array}$ & $\begin{array}{l}\text { SKU, could be either } \\
\text { high- or low equity } \\
\text { products }\end{array}$ & $\begin{array}{l}\text { Nationwide, in all } \\
\text { retail chains }\end{array}$ \\
\hline Brand delistings & Unspecified & Yes & $\begin{array}{l}\text { Long-term } \\
\text { (permanent) }\end{array}$ & $\begin{array}{l}\text { Brand, could be either } \\
\text { high- or low equity } \\
\text { products }\end{array}$ & $\begin{array}{l}\text { All stores of one } \\
\text { retail chain }\end{array}$ \\
\hline $\begin{array}{l}\text { Conflict } \\
\text { delistings }\end{array}$ & Channel conflict & Yes & $\begin{array}{l}\text { Short-term } \\
\text { (typically few } \\
\text { weeks) }\end{array}$ & $\begin{array}{l}\text { Brand/ SKU, could be } \\
\text { either high- or low } \\
\text { equity products }\end{array}$ & $\begin{array}{l}\text { All stores of one } \\
\text { retail chain }\end{array}$ \\
\hline
\end{tabular}

\subsubsection{Gap \#2: Conditions under Which Conflict Delistings are More or Less Harmful}

There is an extensive literature stream on inter-organizational conflicts, in which various aspects of conflicts have been investigated. Prior literature mainly focused on the antecedents of channel conflicts and its consequences for 'soft' measures, such as channel satisfaction (for two overview papers see Gaski 1984 and Geyskens, Steenkamp, and Kumar 1999). Other studies in this field have investigated conflicts from another perspective and focused on conflict prevention mechanisms and resolution techniques (e.g., Koza and Dant 2007; Mohr and Spekman 1994; Song, Xie, and Dyer 2000). Interestingly, prior studies typically consider the conflict a singlefaceted factor and do not distinguish between different conflict characteristics. However, the impact of conflict delistings on performance may be contingent upon specific conflict characteristics (Sloot and Verhoef 2008; Van der Maelen, Breugelmans, and Cleeren 2017). Empirical research which allows for a multidimensional approach unraveling the conditions in which the performance consequences of conflict (delistings) are more or less harmful is missing.

\subsubsection{Gap \#3: How to Respond to Conflict Delistings?}

Companies often rely on managerial actions such as advertising support and price reductions to attract consumers (e.g., Grover and Srinivasan 1992; Srinivasan et al. 2004). In traditional retail settings, increasing advertising support and engaging in price reductions increase manufacturer and retailer sales (e.g., Bijmolt, Van Heerde, and Pieters 2005; Sethuraman, Tellis, and Briesch 2011). However, the effectiveness of 
managerial actions changes considerably when faced with a crisis situation (Van Heerde, Helsen, and Dekimpe 2007). In some crisis situations, a particular marketing action may be highly efficient, while in other situations, the same action renders ineffective in attracting consumers (Cleeren, Van Heerde, and Dekimpe 2012) or might even backfire. Accordingly, the effectiveness of strategic actions, such as advertising support and price reductions, is likely to be different when the manufacturer and retailer face a conflict delisting compared to 'normal' situations, given the intrinsic characteristics of a conflict delisting (e.g., change in brand equity due to the conflict delisting, presence of publicity surrounding the conflict, attribution of blame by consumers). However, empirical evidence on this topic is missing, leaving companies in the dark about the appropriate response to a conflict delisting.

\subsection{CONTRIBUTIONS OF THIS DISSERTATION}

The objective of this dissertation is to help fill the three identified gaps by answering the following questions.

\subsubsection{What are the Performance Implications of Conflict Delistings?}

Two different perspectives shed light on this question. In Chapter 2, a consumer perspective will provide insights into the sales consequences of conflict delistings for both manufacturers and retailers. A large sample of conflict situations will be analysed, allowing for empirical generalizations on the consequences of conflict delistings.

Chapter 3 takes an investor perspective, in which the impact of conflict delistings on shareholder value is examined. Shareholder value is forward looking (Geyskens, Gielens, and Dekimpe 2002) and a reflection of all future changes in cash flows (Chaney, Devinney, and Winer 1992). Therefore, the change in shareholder value captures the full impact of conflict delistings on firm value, including consumer reactions, expected change in profit margins, reactions from other negotiation partners, and potential damages in the manufacturer-retailer relationship.

\subsubsection{In Which Situations are the Performance Consequences More or Less Severe?}

This dissertation will consider conflict as a heterogeneous concept, and distinguish between different conflict characteristics. Both in Chapter 2 and 3, contingency frameworks will be developed that specify conditions under which performance consequences of conflict delistings will be more or less severe. To exemplify, the contingency frameworks provide insights into the contingency role of the publicity surrounding the delisting, the initiator of the delisting, and the number of products that are delisted. 


\subsubsection{Which Strategy is Beneficial to Alleviate Negative Consequences of a Conflict Delisting?}

Chapter 2 will shed light on the effectiveness of various strategic actions (i.e., advertising support and price reductions) that manufacturers and retailers can use to protect themselves from the potentially harmful consequences of conflict delistings.

\subsection{OBJECTIVES AND STRUCTURE}

The objective of this dissertation is to unravel the performance implications of conflict delistings. To this end, I composed a unique and extensive database comprising all conflict delistings from 2000-2016 in four European countries (i.e., Belgium, Germany, The Netherlands, United Kingdom). The data was collected by means of an extensive media search in trade press sources and national newspapers. This multitude of cases spanning different countries, categories, manufacturers, and retailers - does not only allow for empirical generalizations on the performance consequences of conflict delistings, the variability between the cases also provides insights into the potential contingent impact of various conflict characteristics such as the initiator of the conflict and the publicity around the conflict delisting. This database is the input for two empirical studies dedicated to the objective. Both chapters tackle the issue from a different perspective, thereby providing a well-rounded picture into the impact of conflict delistings. Table 1.2 provides an overview of the two essays.

\subsubsection{Chapter 2: The Effectiveness of Managerial Actions during Conflict Delistings}

Chapter 2 focusses on consumer reactions to conflict delistings. Conflict delistings significantly disrupt consumers' usual shopping behaviour. Due to the unavailability of the product, consumers are forced to alter their shopping behaviour, and have to decide whether to visit a different store to purchase the delisted product (and possible other products) or to select a different product within the involved retailer (e.g., Sloot and Verhoef 2008). The former will harm a retailer's sales, while the latter will negatively influence a manufacturer. I utilize and build upon Heider's balance theory (1958) and postulate that who a consumer sides with will depend on the managerial actions of the conflicting parties (i.e., advertising support and price reductions) and the specific conflict situation (i.e., initiator of the conflict and amount of publicity surrounding the conflict). Subsequently, I theorize and test in which conflict situations which managerial actions are more effective. The results of the study will therefore provide a marketing dashboard guiding both manufacturers and retailers on which marketing actions are more effective in different types of conflict situations. 
Table 1.2: General Overview of Dissertation

\begin{tabular}{|c|c|c|}
\hline & Chapter 2 & Chapter 3 \\
\hline Research question & $\begin{array}{l}\text { Which marketing actions are best suited } \\
\text { in which particular conflict situation to } \\
\text { mitigate potential losses resulting from } \\
\text { conflict delistings? }\end{array}$ & $\begin{array}{l}\text { How do conflict delistings influence firm } \\
\text { value, and how is the performance impact } \\
\text { of conflict delistings contingent upon the } \\
\text { seriousness of the conflict and the } \\
\text { capacity to withstand negative } \\
\text { consequences? }\end{array}$ \\
\hline Research perspective & Consumer responses & Investor responses \\
\hline Performance measure & Brand and category sales & Shareholder value \\
\hline Sample & $\begin{array}{l}187 \text { cases in brand sales model \& } \\
577 \text { cases in category sales model, } \\
\text { period } 2001 \text { - } 2015 \text {, } \\
\text { four European countries }\end{array}$ & $\begin{array}{l}69 \text { cases of listed companies, } \\
\text { period } 2000-2016, \\
\text { four European countries }\end{array}$ \\
\hline Data types & $\begin{array}{l}\text { Advertising data, household scanner } \\
\text { data, newspaper databases, trade press } \\
\text { sources }\end{array}$ & $\begin{array}{l}\text { Annual reports, financial databases, } \\
\text { newspaper databases }\end{array}$ \\
\hline Methodology & Market response model & Event study methodology \\
\hline
\end{tabular}

\subsubsection{Chapter 3: The Market Valuation of Conflict Delistings}

Chapter 3 takes an investor perspective to conflict delistings. Besides consumer reactions, conflict delistings might influence firm value through its effects on profit margins and changes in the manufacturer-retailer relationship (Sloot and Verhoef 2008), and even negotiations with other marketing channel partners. I unify these effects and investigate the impact of conflict delistings on total firm value. Subsequently, I build a contingency model to investigate in which conflict situations conflict delistings will be more or less harmful. I distinguish between the seriousness of the delisting (i.e., elimination size and amount of publicity surrounding the delisting) and the capacity to withstand the negative consequences of the delisting (i.e., initiating party, firm size focal firm, and firm size opponent).

\subsection{OUTLINE OF DISSERTATION}

This dissertation is based on two empirical studies described in Chapters 2 and 3. While they share the common theme of conflict delistings and its impact on firm performance, they differ in their underlying perspectives and emphasis. Chapter 2 focusses on consumer reactions to conflict delistings, and the subsequent managerial actions that are most suitable in an array of conflict situations. Chapter 3 investigates the impact of conflict delistings on firm value, by examining investor responses around the conflict announcement. Finally, Chapter 4 summarizes the findings and provides a general conclusion to the dissertation, discusses the main managerial implications, and offers suggestions for future research. 

Chapter

\section{The Effectiveness of Managerial Actions} during Conflict Delistings 



\subsection{INTRODUCTION}

While bargaining power clearly used to be on the manufacturer's side a few decades ago, retailers have grown into large, concentrated players which make them a powerful counterparty for manufacturers (Dawar and Stornelli 2013). This change of balance of power can turn negotiations into true power conflicts (Hingley 2005; Kumar, Scheer, and Steenkamp 1995). A prevalent instrument for resolving conflicts is the use of coercive power (Frazier and Summers 1984), where the manufacturer or retailer may decide to delist the afflicted brands from the retailer's assortment. We refer to this phenomenon as conflict delistings. To exemplify, retailer Tesco removed at least 160 Premier Foods products from the shelves due to a pricing spat (The Grocer 2011c), while manufacturer giant Unilever decided to cease the delivery of their butter brand to popular German retailer Rewe (Lebensmittelzeitung 2013). While the use of coercive power in the form of conflict delistings might be effective in gaining compliance from the other party (Frazier and Summers 1984), they can seriously harm both manufacturer and retailer sales, due to consumers switching to alternative brands within the store and consumers switching between stores, respectively (Van der Maelen, Breugelmans, and Cleeren 2017).

In light of these potential devastating consequences, both manufacturers and retailers rely heavily on their advertising and price actions in an attempt to protect themselves from the damaging effects. For instance, when beer brand Paulaner was delisted from popular German supermarkets Real and Extra, it started a huge poster campaign to induce consumers to switch stores (Lebensmittelzeitung 2007), while Coca-Cola offered price promotions for Fanta at other retailers when it was delisted from Superunie in The Netherlands (Distrifood 2005b). In addition to differences in the use of the advertising and price actions, there is also a lot of heterogeneity between different conflict situations. For example, whereas some conflicts are widely covered in top national newspapers (e.g., Albert Heijn - Coca-Cola conflict in 2007 which was covered in $90 \%$ of the national newspapers), others receive little to no publicity (e.g., Sainsbury - Pepsi conflict in 2011 which was not covered in any of the national newspapers). Furthermore, the conflict can be initiated by either the manufacturer, for example by demanding higher prices, or by the retailer, for example by trying to decrease wholesale prices. Despite the potential tremendous impact of a conflict delisting on manufacturer and retailer sales, both parties are clueless on the appropriate course of action when confronted with such an event.

Despite the inherent managerial importance, current research offers little guidance on this issue (Sloot and Verhoef 2008; Van der Maelen, Breugelmans, and Cleeren 2017). While Van der Maelen, Breugelmans, and Cleeren (2017) study the market share consequences of a particular conflict delisting in different categories, they do not study the effectiveness of advertising and price to mitigate the potential negative consequences of the delisting. We draw upon balance theory (Heider 1958) to provide 
insights into the effectiveness of these marketing actions in different conflict delisting circumstances. This theory posits that, to fulfill the need for internal balance (Heider 1958), consumers will side with either the manufacturer or retailer when these parties are faced with a conflict delisting, thereby influencing their sales numbers. However, until now, studies using balance theory remain agnostic with regard to how exactly consumers make the decision to choose one side over the other, i.e., whether parties can persuade the consumer with their marketing actions or whether the choice is completely context-dependent.

We compose a unique and extensive database on conflict delistings that occurred between 2001 and 2013 in the Netherlands, the United Kingdom, Germany, and Belgium. We observe the sales consequences for afflicted manufacturers and retailers in the context of conflict delistings for 187 affected brands and 577 affected retailer categories. Included categories range from toilet paper to cleaning products, soups, and olive oils. We use market response models to investigate the impact of the conflict, marketing actions (i.e., advertising and price), conflict characteristics (i.e., publicity and initiator), and their interaction effects on manufacturer and retailer sales.

We contribute to the literature in four ways. First, we contribute to and expand Heider's balance theory (1958). In marketing, balance theory is mainly used in the context of sponsorship arrangements (e.g., Mazodier and Merunka 2012), gift giving (e.g., Lowrey, Otnes, and Ruth 2004), sales employee-consumer relationships (e.g., Frey, Bayón, and Totzek 2013), and business-to-business relationships (e.g., Peterson 2006). As such, balance theory is mainly used to explain the occurrence of a spillover effect from one relationship to another (e.g., a sponsorship with a favorite celebrity leads to an increased brand image). However, the basis on which a consumer chooses one party over another in case of disruptions of the balance is unclear. We aim to fill this gap by investigating how the use of persuasion techniques by either involved party (i.e., advertising and price decisions by the manufacturer and retailer) can influence this decision. In addition, although Heider (1958) pointed at the relevance of the contextual factors attribution and awareness of the event, there is no empirical evidence substantiating these claims. Since we will study the effect of the amount of publicity surrounding the conflict and the initiator of the conflict, we contribute to this theory.

Second, previous research identified managerial actions (e.g., advertising and price) as important tools for companies to persuade consumers to purchase a manufacturer's brand (e.g., Srinivasan et al. 2004) or visit a retailer's store (e.g., Grover and Srinivasan 1992). However, the effectiveness of marketing actions changes considerably when consumers are faced with a crisis situation (Van Heerde, Helsen, and Dekimpe 2007). Consequently, given the intrinsic characteristics of conflict delistings, the effectiveness of advertising and price decisions are likely to work differently from 'normal' situations. Surprisingly, no empirical evidence is available on the effectiveness of these 
managerial actions during conflict delistings (Van der Maelen, Breugelmans, and Cleeren 2017).

Third, in addition to persuasive techniques, contextual factors (i.e., conflict characteristics) may play a large role when consumers decide who to side with (Heider 1958). While there is an extensive literature stream concerning inter-organizational conflicts providing insights into the antecedents (e.g., Gaski 1984) and consequences of conflicts (e.g., Lusch 1976), as well as prevention and resolution methods (e.g., Koza and Dant 2007; Mohr and Spekman 1994; Song, Xie, and Dyer 2000), these studies do not distinguish between different conflict contexts. A more heterogeneous approach, in which a distinction is made between different conflict characteristics, is clearly needed. Therefore, we follow Heider's (1958) recommendation and investigate the impact of awareness (i.e., publicity) and causal attribution (i.e., the initiator of the conflict).

Finally, the importance of identifying boundary conditions for existing theory has been emphasized (Whetten 1989). More specifically, previous research points at the relevance of finding these boundary conditions for the advertising and pricing literature (Cleeren, Van Heerde, and Dekimpe 2013). However, empirical evidence in this area is scarce. We therefore analyze whether the effectiveness of advertising and price depends on the conflict situation, i.e., the amount of publicity and the initiator of the conflict. The results of the study create a marketing dashboard, providing guidelines for both manufacturers and retailers on which marketing actions to use in which particular conflict situation to mitigate potential losses resulting from conflict delistings.

The remainder of this paper is organized as follows. First, we review the literature on manufacturer-retailer power and the role of the consumer in this relationship. In particular, we draw upon Heider's (1958) balance theory as the basis of our conceptual framework. Then, we introduce the hypotheses, describe the methodology and data, and present the results. Finally, we discuss the theoretical and managerial implications, and provide limitations of our study and fruitful directions for future research.

\subsection{CONCEPTUAL FRAMEWORK}

The nature of interaction between manufacturers and retailers has received a vast amount of attention in the last 20 years (Ailawadi et al. 2010). In these last decades, the manufacturer-retailer relationship has been subject to substantial structural changes. In the past, manufacturers clearly dominated the retailing landscape, which allowed them to enforce their prices and buying conditions on the typically small retailers. Throughout the decades, a shift in power has taken place due to the rise of store brands (Ailawadi 2001; Draganska, Klapper, and Villas-Boas 2010), availability of scanner data (Chu and Messinger 1998), scarcity in shelf space (Ailawadi, Borin, and 
Farris 1995), pass-through of trade promotions (Ailawadi et al. 2010), and the growing consolidation of retail chains (Aalto-Setälä 2002; Dawar and Stornelli 2012; Messinger and Narasimhan 1995). Retailers have now grown to be players of significant size, leading to a different power balance in the retailing market. On the one hand, manufacturers can leverage their ownership of national brands. As retailers depend on national brands to generate store traffic, manufacturers have negotiation power over retailers (Shankar, Carpenter, and Farley 2012). On the other hand, retailers ultimately decide which brands to carry in their assortment (Dukes, Geylani, and Srinivasan 2009), giving them negotiation power over the manufacturer. In a conflict situation, both parties may attempt to exert their power, by means of a temporary delisting of products, in an attempt to influence the other's behavior. This negative, adversarial manufacturer-retailer relationship should not be considered in isolation. Rather, the effects of conflict delistings may be better understood if the relationships beyond the dyadic level are studied. Indeed, power abuse in the form of conflict delistings by either the manufacturer or retailer affects not only the conflicting parties (i.e., the involved manufacturer and retailer) but also consumers, implying that different relational dynamics are in place. To discuss these relational dynamics, we draw upon balance theory (Heider 1958).

According to balance theory, triadic relationships can either be balanced or unbalanced. A balanced triadic relationship is characterized by either three positive relations or one positive and two negative relations within the triad. In our research context, a balanced state occurs in the absence of a conflict delisting because the triadic relationship consists of three positive relations (see Figure 2.1, Panel A): the retailer carries the particular brand from the manufacturer (positive), and the consumer purchases the manufacturer's brand (positive) at the retailer (positive). An unbalanced triadic relationship, on the other hand, is characterized by either two positive and one negative relation or three negative relations. When a conflict escalates to the point that brands are delisted, an unbalanced triadic relationship arises. Indeed, the positive manufacturer-retailer relationship turns into a negative one (see Figure 2.1, Panel B).

The basic premise of balance theory is that people have an internal need for a congruent or balanced state within a triad (Heider 1958). Individuals who find themselves in an unbalanced state will experience psychological tension, which may lead to stress and reduced well-being (Burroughs and Rindfleisch 2002) and, thus, are expected to change their attitudes, actions, or relations to move toward a balanced state. Thus, in the context of conflict delistings, consumers have to adjust their relationship with either the manufacturer or the retailer in order to return to a balanced state. More specifically, when faced with a conflict delisting, consumers can switch to a different store in order to obtain the manufacturer brand (choosing to side with the manufacturer) or to a different brand within the store (choosing to side with the retailer). 
Panel 1A: Pre Conflict Delisting

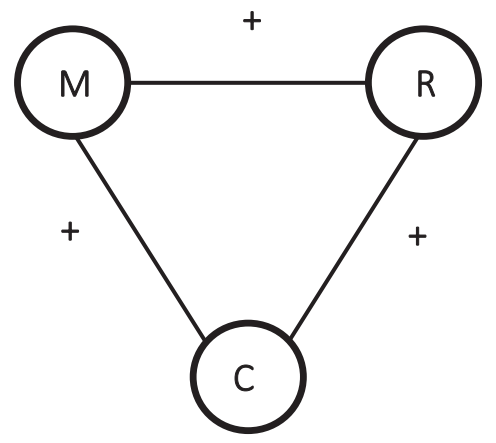

Panel 1B: Post Conflict Delisting

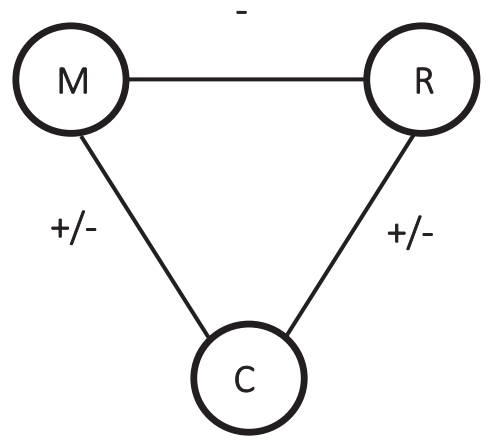

Figure 2.1: Heider's Balance Theory

Where " $M$ " denotes manufacturer, " " retailer, and " $\mathrm{C}$ " consumer.

The ultimate choice depends on the ratio between the costs of switching brands and the costs of switching stores, and manufacturers and retailers are free to alter the balance in their favor (Thain and Bradley 2012). They induce switching behavior by extrinsic incentives or marketing actions. In particular, both manufacturers and retailers attempt to alleviate brand- and category-sales losses by increasing advertising support or by offering price discounts. Our main objective is to find out in which situations which managerial actions are more effective. We therefore develop formal hypotheses for the various interaction effects. For the main effects of the marketing actions and conflict characteristics, we briefly review prior literature and include them in our empirical model.

The literature is divided as to whether advertising support alleviates sales losses resulting from conflict delistings. On the one hand, advertising may amplify the occurrence of the conflict delisting and, in turn, aggravate the damage caused by the delisting (Liu and Shankar 2015). Moreover, as a conflict delisting indicates a lack of ability and willingness to deliver certain products to consumers, the manufacturer's and retailer's credibility is likely to be harmed (Van Heerde, Helsen, and Dekimpe 2007). As credibility is a crucial requirement for companies to get consumers to believe their advertising claims (Goldberg and Hartwick 1990), advertising efforts are hampered if company credibility is harmed (Aaker 1991; Goldberg and Hartwick 1990). On the other hand, advertising informs consumers about the existence of the conflict delisting and provides information on the availability of the delisted products at other retailers or information on available, alternative products at the same retailer. Further, the conflict delisting may increase the awareness of the afflicted brand and retailer (Cleeren, Van Heerde, and Dekimpe 2013), making advertising more effective during a conflict situation. 
Also the effect of price discounts on brand and category sales is ambivalent at the time of a conflict delisting. On the one hand, it could be argued that price discounts reduce the manufacturer's and retailer's credibility - on top of the credibility loss inherent to conflict delistings. On the other hand, conflict delistings make consumers more price sensitive for several reasons. First, conflict delistings generally place a lot of emphasis on prices, as they typically occur due to price negations gone sour. Second, negative information about manufacturers or retailers may increase price sensitivity (Cleeren, van Heerde, and Dekimpe 2013; Erdem, Swait, and Louviere 2002). Further, the reduced manufacturer's and retailer's credibility increase information search and processing costs, which in turn may increase price sensitivity (Erdem, Swait, and Louviere 2002; Lynch and Ariely 2000). The heightened price awareness and sensitivity of consumers may make price discounts more effective (Van Heerde, Gijsbrechts, and Pauwels 2008). In addition, consumers may perceive price discounts as a financial compensation for the conflict situation. Previous research indicates that financial compensation has a positive effect on the level of satisfaction after a failure in general (Folkes 1984) and may offset any negative reactions that a consumer may have in case of product unavailability (Anderson, Fitzsimons, and Simester 2006), making price discounts an effective marketing instrument in case of a conflict delisting.

The extent to which advertising support and price discounts are effective in alleviating sales losses resulting from conflict delistings is likely to be contingent on the specific conflict situation. Previous studies have shown that the effectiveness of marketing actions is dependent on situational characteristics (e.g., Cleeren, Van Heerde, and Dekimpe 2013). In a similar vein, we argue that the effectiveness of advertising support and price reductions is contingent upon the amount of publicity surrounding the conflict delisting and the initiator of the conflict. This is in line with Heider (1958) who identified awareness of the event and causal attribution as important factors when evaluating heteronomous events, such as conflict delistings. Therefore, we include publicity and conflict initiator as key conflict characteristics.

Publicity represents an environmental effect that increases the awareness of the conflict delisting. It refers to earned media or media that a company does not directly generate themselves (Stephen and Gallak 2012), such as press mentions in national newspapers. Although conflict delistings are covered extensively in the independent press, little attention has been paid to how publicity affect advertising and pricing effectiveness in alleviating sales losses from conflict delistings.

The conflict can be initiated by either the manufacturer or the retailer, which may influence the causal attribution of the event. Manufacturers often initiate a conflict delisting if retailers do not accept the demand for higher wholesale prices for their products. To exemplify, in 2009 German mineral water manufacturer Gerolsteiner demanded higher wholesale prices from retailer Real. When Real refused to agree with this demand, Gerolsteiner initiated a conflict delisting (Lebensmittelzeitung 2009). Retailers can put their foot down and cause a conflict as well, for example if buying 
conditions are not improved (Sloot and Verhoef 2008), by demanding a lower wholesale price from the manufacturer (Distrifood 2005c), or by pressuring the manufacturer after a stunt with price reductions at hard discounters (Lebensmittelzeitung 2004).

We theorize and test how the effectiveness of advertising support and price discounts is affected by the conflict situation, i.e., publicity and initiator of the conflict. Figure 2.2 summarizes our conceptual framework.

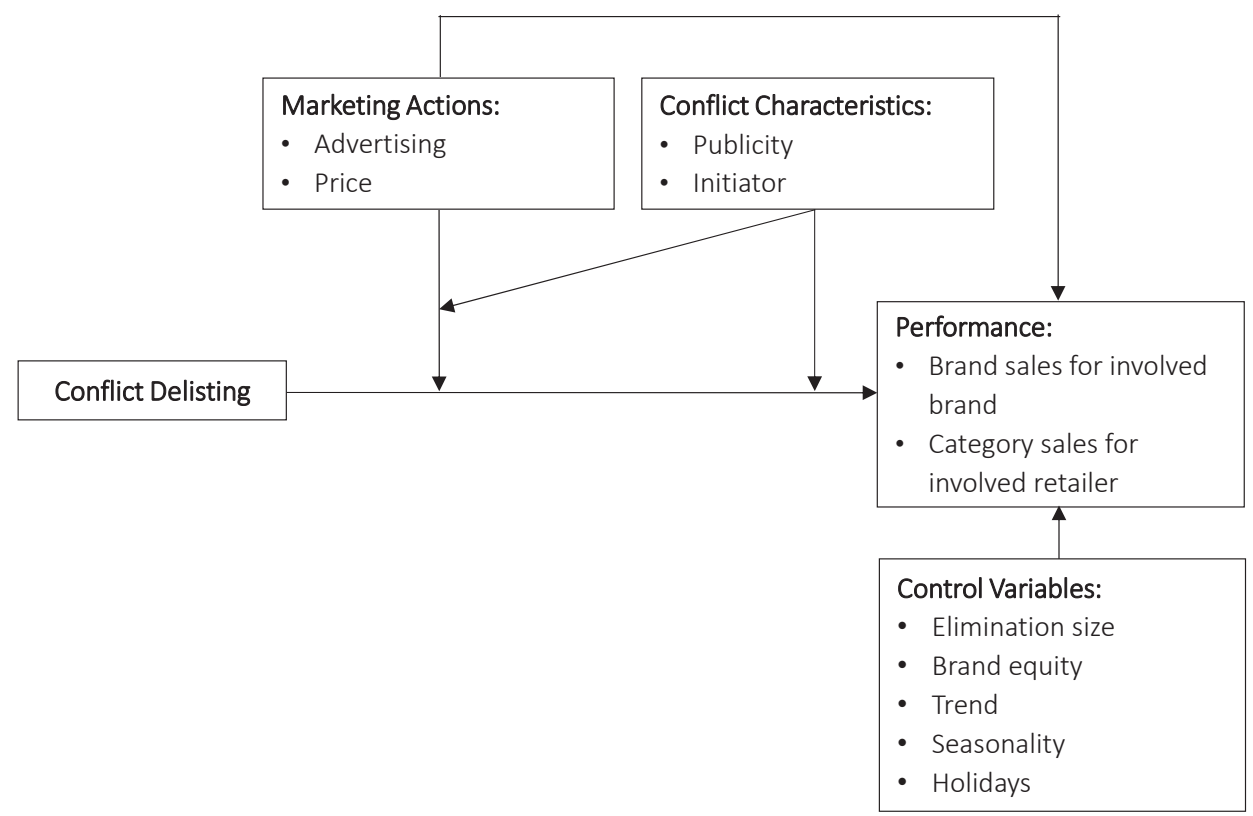

Figure 2.2: Conceptual Framework

\subsubsection{The Effectiveness of Marketing Actions and Publicity}

Conflict delistings are often accompanied by publicity (Van der Maelen, Breugelmans, and Cleeren 2017). Media provide negative information about brands and companies by making consumers aware of the adversarial relationship between the involved manufacturer and retailer.

Advertising and publicity. People have the natural tendency to place more trust in messages from independent media compared to advertisement campaigns due to higher source credibility (e.g., Eisend and Küster 2011; Lord and Putrevu 1993). Since negative publicity has higher source credibility than the advertising it is paired with (Stammerjohan et al. 2005) and negative information is given more weight than positive information (Ahluwalia, Burnkrant, and Unnava 2000), we propose that advertising effectiveness is lower for conflict delistings that receive publicity than for conflicts that receive little or no publicity. 
Moreover, according to contrast theory, when consumers are exposed to either advertising or publicity that delivers inconsistent information, the combined effect will be much more negative than the publicity-only (Kim, Yoon, and Lee 2010) or advertising-only condition (Smith and Vogt 1995). Thus, while manufacturers and retailers allocate advertising budgets with the goal of spreading positive information (e.g., availability of brands at other retailers, availability of alternative brands within the retailer), publicity, which is negative in nature when a conflict occurs, renders advertising support less effective. We therefore hypothesize:

$\mathrm{H} 1$ : When a conflict is surrounded by publicity, advertising becomes less effective for both a) the manufacturer, and b) the retailer, compared to when the conflict is not surrounded by publicity

Price and publicity. Negative publicity may decrease the perceived differentiation of the affected brand or retailer (Ahluwalia, Burnkrant, and Unnava 2000). Indeed, due to the conflict delisting, consumers are forced to compare alternative brands within the category or switch to an alternative retailer, which could lead to an increase in the magnitude of the brands' or retailers' price elasticity (Cleeren, Van Heerde, and Dekimpe 2013; Van Heerde, Helsen, and Dekimpe 2007). In addition, publicity increases the awareness of a conflict (Van Heerde, Gijsbrechts, and Pauwels 2015) including the underlying cause, prevailingly price negotiations that gone sour. Previous literature reveals that price conflicts (i.e., price wars) make consumers more price sensitive (Van Heerde, Gijsbrechts, and Pauwels 2008), indicating consumers are more likely to purchase a product when the price is lower (Tellis 1988). Therefore, price reductions are more effective when the conflict delisting receives publicity. We hypothesize:

$\mathrm{H} 2$ : When a conflict is surrounded by publicity, price reductions become more effective for both a) the manufacturer, and b) the retailer, compared to when the conflict is not surrounded by publicity

\subsubsection{The Effectiveness of Marketing Actions and the Initiator of the Conflict}

Consumers perceive a conflict delisting as an event that violates a norm. Indeed, a conflict or unavailability causes irritation amongst consumers (Sloot, Verhoef, and Franses 2005) as they are forced to alter their usual shopping behavior. Additionally, they believe that the manufacturer or retailer is causally linked to the norm violation. In other words, they hold either the manufacturer or retailer responsible for the conflict delisting. Because consumers detect a conflict delisting and determine that either the manufacturer or retailer caused the conflict delisting, blame emerges (cf. Malle, Guglielmo, and Monroe 2014). Causal attribution theory dictates that consumers assign blame to the party that is responsible for the failure (Folkes 1984), in this case the firm that initiated the conflict. Attribution of blame forms the basis of 
consumers' judgments and behavior (Klein and Dawar 2004), rendering advertising support and price reductions more or less effective.

Advertising and conflict initiator. Advertising support is less effective for the initiating party of the conflict, for two reasons. First, because the conflict initiator is blamed, its credibility will be hurt, resulting in reduced brand equity (Erdem and Swait 1998). As a consequence, advertising effectiveness will be hampered (Aaker 1991; Goldberg and Hartwick 1990; Van Heerde, Helsen, and Dekimpe 2007). Second, while the conflict initiator is willing to demonstrate its sympathy with its consumers through advertising, consumers may question the trustworthiness and feel skepticism and suspicion (cf. Priester and Petty 2003). Allocating large budgets to advertising spending while at the same time initiating a conflict delisting to bargain for lower prices may be perceived as inconsistent. Hence, this may run the risk of reducing consumer trustworthiness and decrease the effectiveness of the advertising campaign.

On the contrary, advertising support is more effective for the non-initiating party. When a consumer blames one party they implicitly choose to side with the other party, due to their inner need for a balanced state (e.g., Heider 1958). Thus, the non-initiating party will not lose credibility and its advertising claims are perceived as trustworthy, rendering advertising support more effective. Therefore, we hypothesize the following:

H3: When the focal company initiated the conflict delisting, advertising becomes a) less effective for the focal company, and b) more effective for the opponent, compared to when the focal company did not initiate the conflict delisting.

Price and conflict initiator. Consumers believe that problems arising from firms' actions should be solved by firms (Folkes 1988). Thus, consumers feel they deserve financial compensation and apologies from the initiator of the conflict (Folkes 1984). Price discounts are a way to (financially) compensate the consumer for the inconvenience caused by the conflict delisting (Anderson, Fitzsimons, and Simester 2006; Folkes 1984), making price an effective marketing tool to alleviating sales losses for the conflict initiator. Additionally, the reduced credibility from initiating a conflict further increases the effectiveness of price discounts (Erdem, Swait, and Louviere 2002). In contrast, the credibility of a non-initiating party may increase due to a conflict delisting, rendering price reductions less effective (Erdem, Swait, and Louviere 2002). We hypothesize:

H4 When the focal company initiated the conflict delisting, price reductions become a) more effective for the focal company, and b) less effective for the opponent, compared to when the focal company did not initiate the conflict delisting. 


\subsection{MODEL}

We study the effects of marketing actions, conflict characteristics, and the interactions between these on manufacturer and retailer sales in the context of a conflict delisting.

\subsubsection{Model Specification}

To estimate the impact on manufacturer and retailer performance, we estimate one model for brand sales (BS) and one for category sales (CS), respectively. We use two market response models to assess the impact of the marketing actions, conflict characteristics, and the interaction effects. We model the (normalized) ${ }^{1}$ brand sales for the afflicted brand in the afflicted category (hereafter referred to as brand-category combination $b$ ) and week $t$ as follows:

$$
\begin{aligned}
& B S_{b t}^{*} \quad=\beta_{1}^{B S} \text { Start delisting }{ }_{b t} \\
& +\beta_{2}^{B S} \text { Relative brand advertising }{ }_{b t} \\
& +\beta_{3}^{B S} \text { Relative brand price }{ }_{b t} \\
& +\beta_{4}^{B S} \text { Relative brand advertising } g_{b t} * \text { Start delisting } g_{b t} \\
& +\beta_{5}^{B S} \text { Relative brand } \text { price }_{b t} * \text { Start delisting }{ }_{b t} \\
& +\beta_{6}^{B S} \text { Publicity }_{b t}+\beta_{7}^{B S} \text { Initiator }_{b t} \\
& +\beta_{8}^{B S} \text { Relative brand advertising }{ }_{b t} * \text { Publicity }_{b t}
\end{aligned}
$$

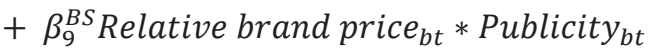

$$
\begin{aligned}
& +\beta_{10}^{B S} \text { Relative brand advertising } \text { ant } * \text { Initiator }_{b t} \\
& +\beta_{11}^{B S} \text { Relative brand } \text { price }_{b t} * \text { Initiator }_{b t} \\
& +\beta_{12}^{B S} X_{1 b t}+\alpha_{b}^{B S}+\varepsilon_{b t}^{B S}
\end{aligned}
$$

where Start delisting is a dummy variable indicating whether the week falls in the period before $(=0)$ or after the start of the delisting $(=1)$. The $X_{1 b t}$ vector includes the control variables elimination size, brand equity, trend, and seasonal and holiday dummy variables. The $\alpha_{b}^{B S}$ captures the unobserved per-case time-constant effects (e.g., Woolridge 2002). Finally, $\varepsilon_{b t}^{B S}$ depicts the idiosyncratic error term.

Similar to the brand sales model, the (normalized) category sales model for the afflicted category of the afflicted retailer (hereafter referred to as retailer-category combination $c$ ) and week $t$ is specified as follows:

\footnotetext{
${ }^{1}$ To allow for comparison between categories, we make our dependent variable unit free by dividing sales by the average weekly sales in the year before the delisting (cf. Cleeren, Van Heerde, and Dekimpe 2013; Van der Maelen, Breugelmans, and Cleeren 2017), see data section.
} 


$$
\begin{aligned}
& C_{c t}^{*} \quad=\beta_{1}^{C S} \text { Start delisting }{ }_{c t} \\
& +\beta_{2}^{C S} \text { Relative category advertising }{ }_{c t} \\
& +\beta_{3}^{C S} \text { Relative category price }{ }_{c t} \\
& +\beta_{4}^{C S} \text { Relative category advertising }{ }_{c t} * \text { Start delisting }{ }_{c t} \\
& +\beta_{5}^{C S} \text { Relative category price } \text { ct } * \text { Start delisting }{ }_{c t} \\
& +\beta_{6}^{C S} \text { Publicity }_{c t}+\beta_{7}^{C S} \text { Initiator }_{c t} \\
& +\beta_{8}^{C S} \text { Relative category advertising } g_{c t} * \text { Publicity }_{c t} \\
& +\beta_{9}^{C S} \text { Relative category } \text { price }_{c t} * \text { Publicity }_{c t} \\
& +\beta_{10}^{C S} \text { Relative category advertising } \text { ct } * \text { Initiator }_{c t} \\
& +\beta_{11}^{C S} \text { Relative category } \text { price }_{c t} * \text { Initiator }_{c t} \\
& +\beta_{12}^{C S} X_{2 c t}+\alpha_{c}^{C S}+\varepsilon_{c t}^{C S}
\end{aligned}
$$

Similar to $X_{1 b t}$, the $X_{2 c t}$ vector includes the control variables elimination size, brand equity, trend, and seasonal and holiday dummy variables. $\alpha_{c}^{C S}$ captures the unobserved time-constant effects that affect category sales of the different conflict cases (e.g., Woolridge 2002), while $\varepsilon_{c t}^{C S}$ depicts the idiosyncratic error term.

\subsubsection{Endogeneity}

Advertising, price, and the interactions involving these marketing variables might be endogenous to the models as it is possible that brand and category managers employ these actions only when they expect higher sales performance. As a result, the error term may be correlated with the regressors causing inconsistent estimates (e.g., Ebbes, Papies, and Van Heerde 2011). To accommodate the potential endogeneity of advertising, price, and the interaction effects involving these marketing actions, we estimate equations 1 and 2 with 2SLS. We use three broad categories of instrumental variables (IVs): advertising and price of similar but different markets, cost-related variables, and interactions between the established IVs with the conflict characteristics publicity and initiator. Table 2.1 summarizes the main IVs used and indicates the operationalization and data sources. 
Table 2.1: Operationalizations and Data Sources of IVS

\begin{tabular}{|c|c|c|}
\hline IV & Operationalization & Data source \\
\hline $\begin{array}{l}\text { Price unrelated product } \\
\text { classes in same country }\end{array}$ & $\begin{array}{l}\text { Weekly average of the weighted average } \\
\text { lagged prices of the four unrelated product } \\
\text { classes, in the country the delisting took } \\
\text { place. }\end{array}$ & $\begin{array}{l}\text { GfK Netherlands, } \\
\text { t GfK Belgium, } \\
\text { GfK Germany, } \\
\text { Kantar Worldpanel UK household- } \\
\text { panel data }\end{array}$ \\
\hline $\begin{array}{l}\text { Price afflicted product } \\
\text { class in other countries }\end{array}$ & $\begin{array}{l}\text { Weekly weighted average prices of the } \\
\text { afflicted product class, averaged over the } \\
\text { three unrelated countries. }\end{array}$ & $\begin{array}{l}\text { GfK Netherlands, } \\
\text { GfK Belgium, } \\
\text { GfK Germany, } \\
\text { Kantar Worldpanel UK household- } \\
\text { panel data }\end{array}$ \\
\hline $\begin{array}{l}\text { Advertising unrelated } \\
\text { product classes in same } \\
\text { country }\end{array}$ & $\begin{array}{l}\text { Lagged weekly average advertising of the } \\
\text { four unrelated product classes, in the } \\
\text { country the delisting took place. }\end{array}$ & AC Nielsen \\
\hline $\begin{array}{l}\text { Advertising afflicted } \\
\text { product class in other } \\
\text { countries }\end{array}$ & $\begin{array}{l}\text { Weekly average advertising of the afflicted } \\
\text { product class, averaged over the three } \\
\text { unrelated countries. }\end{array}$ & AC Nielsen \\
\hline Unit labor costs & $\begin{array}{l}\text { Country-specific average cost of labor per } \\
\text { unit of output produced. Measured in } \\
\text { percentage changes compared to the same } \\
\text { period in the previous year. }\end{array}$ & $\begin{array}{l}\text { Organization for Economic Co- } \\
\text { operation and Development (OECD) }\end{array}$ \\
\hline
\end{tabular}

Following Nevo's (2001) recommendation, we instrument the marketing actions by using instruments from similar but different markets. We do this in two different ways. First, in line with Van Heerde et al. (2013) we include lagged price and advertising measures for unrelated product classes in the same country. Theoretically, these IVs have the same underlying cost structure that determine changes in advertising and price, while being uncorrelated with demand shocks for the focal product class (Van Heerde et al. 2013). Second, we include the advertising and price measures for the afflicted product class in geographically distant markets as IVs (see Rooderkerk, Van Heerde, and Bijmolt 2013 and Sotgiu and Gielens 2015 for similar practices). Advertising and price measures of different regions will have the same underlying cost structure as our focal region, and can therefore be used as valid instruments. As the conflict delistings occur on a national level, we use the average of the weighted average advertising and price for the three other countries in our dataset as the geographically distant regions as they will not be influenced by the potential demand shock in the focal region. To further capture the development of underlying cost structures for prices, we use the unit labor costs as an IV. Labor cost has been widely used to instrument prices, and has been proven to be a valid and reliable instrument (see for example Chintagunta, Kadiyali, and Vilcassim 2006). As the interactions between the exogenous conflict characteristics (i.e., publicity and initiator) and our endogenous variables advertising and price are by definition also endogenous, the interaction terms between the IVs and publicity and the initiator are also valid 
instruments (Cleeren, Van Heerde, and Dekimpe 2013; Van Heerde et al. 2013). Similarly, we also add interaction terms between the exogenous dummy indicating the start of the delisting and the IVs for advertising and price. We offer more details on the exact operationalization of the variables in the "Data" section.

\subsection{DATA}

To investigate the impact of conflict delistings on manufacturer and retailer sales, we use a unique dataset from different sources. We use a two-step data collection approach. In the first step, we identified all conflict delistings that occurred in The Netherlands (between 2002-2012), United Kingdom (between 2006-2012), Belgium (between 2006-2012), and Germany (between 2004-2012). ${ }^{2}$ The data was collected by means of an extensive search in the trade press sources in that particular country. ${ }^{3}$ To be selected into the sample, the delisting needed to fulfill two criteria. First, the delisting should be caused by a conflict between a manufacturer and a retailer. Second, we only included conflict delistings that occurred in the area of grocery retailing (thereby excluding those that took place in other retailing areas, such as hardware stores).

In step 2, we obtained purchase data, advertising data, and information on the selected conflict characteristics. We obtained household panel data for these conflict delistings from GfK Netherlands (gross panel size=5,750 households), Kantar Worldpanel UK (gross panel size $=25,000$ households), GfK Belgium (gross panel size $=5,100$ households), and GfK Germany (gross panel size=27,000 households). We purchased advertising expenditures for all relevant brands and retailers from AC Nielsen. Furthermore, we obtained information on conflict characteristics through an extensive media search on the specific conflict delistings in the (country-specific) national newspapers using the LexisNexis (Netherlands, United Kingdom, Germany), GoPress and the PressBanking databases (Belgium). ${ }^{4}$ To obtain reliable estimates for

\footnotetext{
${ }^{2}$ The sample period between countries is different due to the availability of data.

${ }^{3}$ Main trade press sources for the different countries are the following: Distrifood (The Netherlands), The Grocer, Marketing Magazine, and Marketing Week (United Kingdom), Gondola and RetailDetail (Belgium), and Lebensmittelzeitung (Germany).

${ }^{4}$ We limited our media search to newspapers with a circulation of at least $1 \%$ of the population. This includes, for the United Kingdom, both the weekly and Sunday editions of (in alphabetical order) Daily Mail, Daily Mirror, Daily Star, The Daily Telegraph, The Express, The Financial Times, The Guardian, The i, The Independent, News of the World, The Observer, The People, The Sun, and The Times, for a total of 18 newspapers. For the Netherlands, we included AD/Algemeen Dagblad, Het Financiële Dagblad, Nederlands Dagblad, NRC Handelsblad, Het Parool, De Pers, Reformatorisch Dagblad, De Telegraaf, Trouw, and De Volkskrant. For Flanders, we included Gazet van Antwerpen, Het Laatste Nieuws, Metro, De Morgen, Het Nieuwsblad, De Standaard, and De Tijd. For Wallonia, we included L'Avenir, La Dernière Heure, L'Echo, La Libre, Metro, and Le Soir. For Germany, this included Focus, Handelsblatt, Frankfurter Rundschau, Der Standard, Die Tageszeitung, die Welt, and Die Zeit. Except for Belgium, free newspapers are not part of the electronic databases, and thus, we could not include them in the media search.
} 
the effectiveness of the marketing variables and the impact of conflict characteristics, we need a sufficiently long period before and after the delistings to ensure that we observe enough purchases in both periods. In line with Gielens and Steenkamp (2007), and given that we study frequently purchased consumer goods with different interpurchase times (Cleeren, van Heerde, and Dekimpe 2013), we gathered all data one year before, during, and one year after the delisting. ${ }^{5}$

In total, we identified 187 brands delisted in different categories in at least one retailer and 577 delistings in categories at different retailers that fulfilled the two criteria specified above. ${ }^{6}$ Note that one conflict situation can affect multiple brands in one category and multiple categories within one retailer. For example, in the UnileverDelhaize conflict (2009), the Unilever brands Axe and Rexona were both delisted in the deodorant category. In addition, in the Premier Foods-Tesco conflict (2011) a wide variety of categories were affected within Tesco, such as dry pasta, vinegar, and packet soup. The number of retailer-category cases is larger than the number of brandcategory cases since a brand can be delisted at multiple retailers of the same buying group at the same time. The cases involve a large range of conflict delistings, ranging from cereals to floor polish, and from mineral water to yoghurt.

\subsubsection{Dependent Variables}

Brand sales (BS) consist of the weekly brand sales in volume. To account for the fact that sales are measured in different volume units over different categories (e.g., kilograms, liters, units), we make our dependent variable unit free by dividing brand sales by the average weekly brand sales in the year before the delisting (cf. Cleeren, Van Heerde, and Dekimpe 2013):

$$
B S_{t}^{*}=\frac{B S_{t}}{\left(\frac{\sum_{S=-11}^{S=-52} B S_{S}}{52}\right)},
$$

where subscript $s$ denotes the week in the year before the delisting (i.e., when s equals -1 it denotes the week before the start of the delisting). In total, we have 20,970 observations for the brand sales model. Category sales (CS) measure the total category volume per week at the afflicted retailer. To obtain a unit-free measure, we again divide it by the average in the year before the delisting:

\footnotetext{
${ }^{5}$ In contrast to the start date, the end date of the delisting is not always mentioned in the trade press. To determine the end of the delisting, we take a closer look at the sales of the delisted brand within the involved retailer. We state that the delisting has ended when the brand sales of the delisted brand at the involved retailer are back at $80 \%$ of the average weekly level in the year before the delisting, after they dropped below the level of $80 \%$. In the robustness section, we test the robustness of this method.

${ }^{6}$ To limit our attention to meaningful cases only, we excluded cases for which the afflicted variety was sold at the afflicted retailer group in less than $50 \%$ of the observed weeks before the delisting.
} 


$$
C S_{t}^{*}=\frac{C S_{t}}{\left(\frac{\sum_{S=-1}^{s}=-S_{s}}{52}\right)}
$$

where subscript $s$ denotes the week in the year before the delisting. In total, we have 64,344 observations for the category sales model. Table 2.2 provides the definitions and summary statistics of the dependent and independent variables.

\subsubsection{Marketing Actions}

For the brand sales model, we specify relative brand price as the grand-mean centered (SKU market-share) weighted average price per volume unit in relation to the main players in the category, i.e., the (market-share) weighted average prices of the five main noninvolved competitors in the category and the involved brand itself. The weight of the competitors' prices and involved brand in the denominator is determined by the market shares of the specific brand in the category in the year before the delisting. Since the prices are net prices, they also reflect possible discounts that the brands may have offered. Also the relative brand advertising is specified relative to the (market share) weighted average advertising of the five main noninvolved competitors and the involved brand and grand-mean centered. ${ }^{7}$

Similarly, for the category sales model, relative category price depicts the grandmean centered weekly (SKU market share) weighted average price per volume unit in the specific category at the involved retailer, expressed relative to the (market-share) weighted average category price of the five largest noninvolved competing retailers and the involved retailer itself.

The weights of the prices in the denominator are again determined by the market share of the retailers in the particular category in the year before the delisting. We identified the five largest noninvolved competitive retailers per country from the market shares of the retailers a year before the delisting, as reported by the Euromonitor database. Relative category advertising is measured by the grand-mean centered advertising of the involved retailer relative to the weighted average of the five largest noninvolved competing retailers and the retailer itself.

\footnotetext{
${ }^{7}$ The monthly advertising data for the United Kingdom, Germany, and Belgium were converted into weekly data. First, the daily advertising was calculated (by dividing the monthly advertising by the days per month). Second, this number was multiplied by 7 to capture the weekly advertising spending.
} 


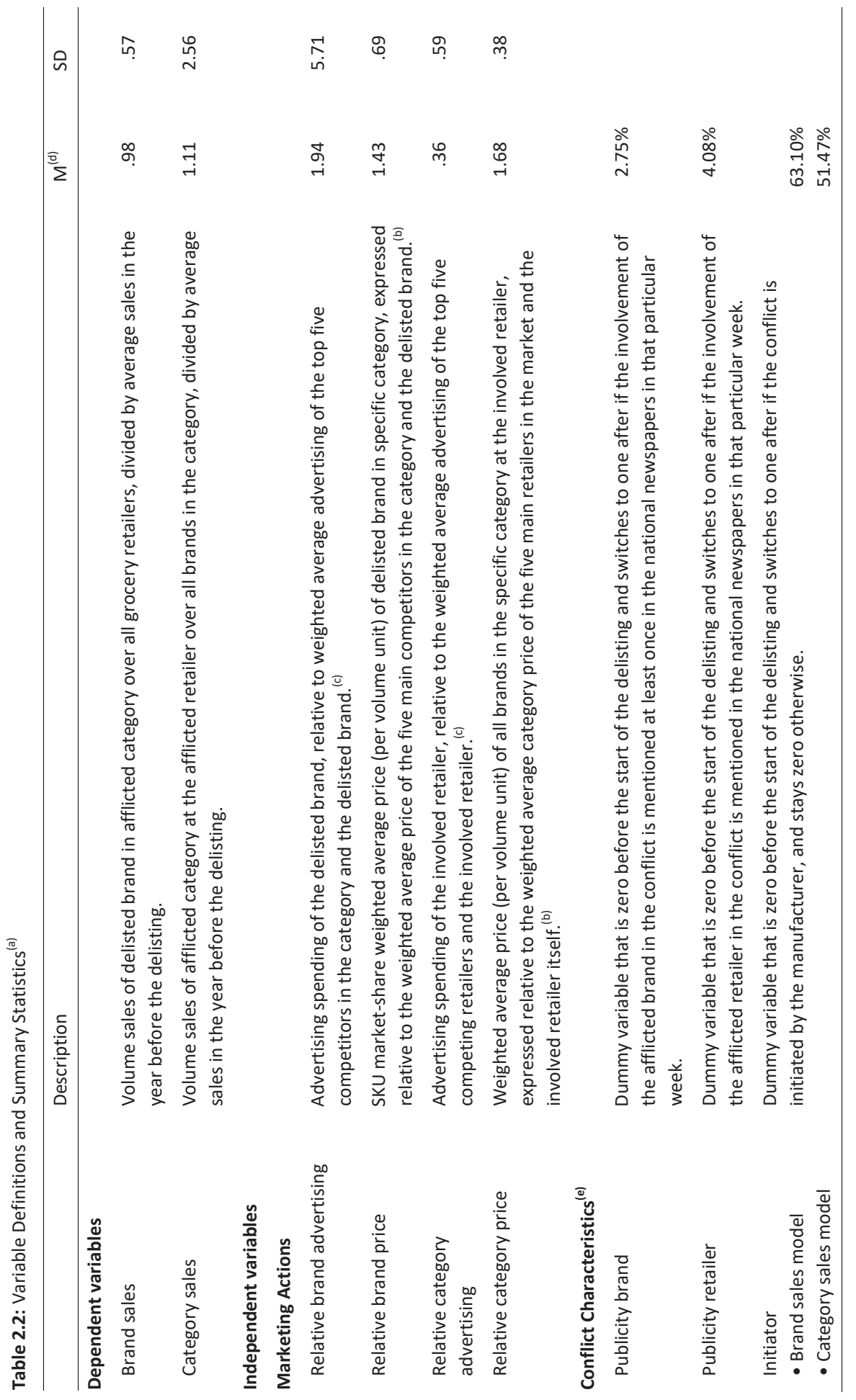


The Effectiveness of Managerial Actions during Conflict Delistings

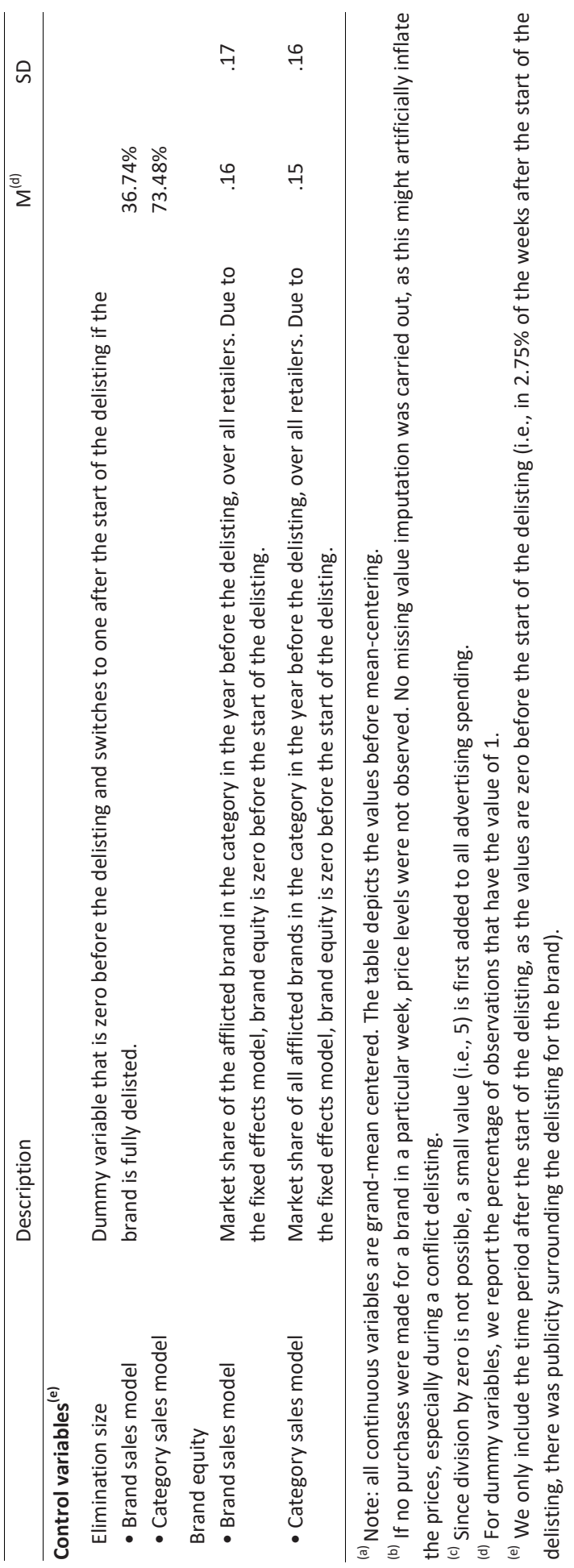




\subsubsection{Conflict Characteristics}

Conflict characteristics were retrieved by an extensive search in the national newspapers and trade press sources. Publicity is a dummy variable which indicates whether the involvement of the brand/retailer in the conflict delisting was mentioned in at least one of the (country-specific) national newspapers (see Cleeren, Van Heerde, and Dekimpe 2013 for a similar operationalization). The dummy variable equals zero before the start of the delisting, and equals one after the start of the delisting if there was publicity in the certain week for the particular brand/retailer (and remains zero otherwise). For the brand-category combinations, there was publicity surrounding afflicted brands in $2.75 \%$ of the weeks after the start of the conflict. For the retailercategory combinations, publicity was generally a little bit higher, as there was media coverage for the afflicted retailer in $4.08 \%$ of the observed weeks after the start of the conflict. Across cases, $\mathbf{7 2 . 7 3 \%}$ of the brand-category combinations were surrounded by publicity, compared to $81.28 \%$ of the retailer-category combinations.

The conflict can either be initiated by the manufacturer or by the retailer. Initiator is a dummy variable, which equals zero before the start of the delisting, and takes the value 1 after the start of the delisting if the manufacturer initiated the conflict and remains zero otherwise. We hereby focus on the initiator of the focal conflict itself (i.e., the firm that demands more favorable conditions in the negotiation process), and not the initiator of the delisting. In total, $53 \%$ of the conflict situations were initiated by a manufacturer, affecting $63 \%$ of our brand-category and $51 \%$ of our retailercategory combinations.

\subsubsection{Control Variables}

In both models, we control for the elimination size of the delisting by including a dummy variable that equals zero before the start of the delisting, and takes the value one after if the full brand is delisted, and stays zero otherwise (in line with Boatwright and Nunes 2001; 2004). We also include the pre-conflict brand equity as a control variable, as this might impact the brand and category sales during the delisting (Van der Maelen, Breugelmans, and Cleeren 2017). For the brand sales (category sales) model, this is the grand mean-centered market share of (all) the delisted brand in the afflicted category in the year before the delisting, over all retailers (for the particular retailer). Due to the time series characteristics of the data, we additionally control for the trend, and possible seasonal and holiday influences. ${ }^{8}$ As mentioned in the model section, start delisting is a dummy variable which takes 1 after the start of the

\footnotetext{
${ }^{8}$ General holidays included are New Year, Good Friday, Easter, Whitsunday, Ascension, Christmas, and Valentine day. Country-specific holidays for the Netherlands are Sinterklaas and Queensday/Kingsday. For the UK the country-specific holidays include Early May, Spring Bank, Summer Bank, Royal wedding, and Queens Jubilee. For Belgium, these are All Hallows, National Holiday, Labour Day, OLV Ascension, and wapenstilstand. Finally, for Germany, we include Labour Day and Day of Unity as country-specific holidays.
} 
delisting, and zero otherwise. More specifically, in line with Cleeren, Dekimpe, and Helsen (2008) the start of the delisting is the date mentioned on the delisting announcement.

\subsubsection{Instrumental Variables}

In line with Van Heerde et al. (2013), we distinguish between the product classes dairy food, non-dairy food, beverages, household care, and personal care to calculate the lagged advertising and price measures for unrelated product classes in the same country. For example, for a dairy brand, we use the average of the (SKU market share) weighted average lagged prices of the non-dairy food, beverage, household care, and personal care as an IV.

We use the average of the (SKU market share) weighted average advertising and price for the three unrelated countries to instrument the afflicted product class in geographically distant markets (see Sotgiu and Gielens 2015 for similar practice). For example, for a delisting that occurred in the Netherlands, we use the average of the (SKU market share) weighted average prices for that particular product class in the UK, Germany, and Belgium as an instrument.

We obtained the unit labor costs via the Organization of Economic Co-operation and Development (OECD). Labor costs are defined as the average costs of labor per unit produced, and are measured in percentage change relative to the same period in the previous year. The data is available on a quarterly basis and is country-specific. In the "Results" section, we report tests that confirm the strength and validity of the IVs.

\subsection{RESULTS}

We formally tested both the validity and strength of our IVs. First, we ran a Sargan test to establish the validity of our IVs (cf. Woolridge 2002). The Sargan statistic is not significant for both the brand-sales $(p>.10)$ and the category-sales model $(p>.10)$ indicating that the null hypothesis that the IVs are uncorrelated with the error term cannot be rejected. In other words, the IVs are sufficiently valid. Next, an incremental F-test is used to measure the strength of the IVs (cf. Dinner, Van Heerde, and Neslin 2014; Sotgiu and Gielens 2015). We regressed each endogenous variable on the exogenous variables in the model, then, we added the IVs and conducted an incremental F-test for the explanatory power of these IVs. The corresponding $p$-values for the exclusion of the IVs suggest that the IVs are sufficiently strong $(p<.01$ for each of the eight endogenous regressors) in both models.

In addition, for both the brand-sales $(F(187,18640), p<.01)$ and the category-sales model $(F(571,54115, p<.01)$ we find a significant F-statistic for the joint statistical significance of the fixed effects. The null hypothesis that the fixed effects $\alpha_{b}^{B S}$ and 
$\alpha_{c}^{C S}$ are all zero can therefore be rejected (Rabe-Hesketh and Skrondal 2008, p.70), which underlines the importance of controlling for fixed effects. Furthermore, we tested the extent of multicollinearity in the models. In Tables 2.3 and 2.4, we report the correlations between the different marketing variables, conflict characteristics, and control variables for, respectively, the brand and category sales model. The maximum correlations are 0.30 (brand sales) and 0.32 (category sales), which are well below 80 (Judge et al. 1998, p. 868). In addition, the maximum variance inflation factors remain well below 10 (Hair et al. 2010), which indicates that multicollinearity is not an issue.

Tables 2.5 and 2.6 show the parameter estimates for the brand-sales (equation 1 ) and category-sales (equation 2) models.

Table 2.3: Correlation Matrix Brand-Sales Model

\begin{tabular}{|c|c|c|c|c|c|c|}
\hline & Advertising & Price & Publicity & Initiator & Brand Equity & Elimination size \\
\hline \multicolumn{7}{|l|}{ Advertising } \\
\hline Price & .27 & & & & & \\
\hline Publicity & .03 & -.00 & & & & \\
\hline Initiator & .01 & .04 & .11 & & & \\
\hline Brand equity & -.10 & -.30 & .04 & .09 & & \\
\hline Elimination size & .09 & .13 & -.03 & .01 & -.19 & \\
\hline
\end{tabular}

Table 2.4: Correlation Matrix Category-Sales Model

\begin{tabular}{lccccc}
\hline & Advertising & Price & Publicity & Initiator & Brand Equity Elimination size \\
Advertising & .06 & & & & \\
Price & .29 & .04 & & & \\
Publicity & .19 & -.08 & .21 & & \\
Initiator & .09 & -.15 & .04 & -.03 & -.07 \\
Brand equity & -.32 & -.01 & -.10 & .29 & -.07 \\
Elimination size & & & & & \\
\end{tabular}


Table 2.5: Empirical Results for the Brand-Sales Model

\begin{tabular}{|c|c|c|}
\hline & Coefficients & Standard error \\
\hline \multicolumn{3}{|l|}{ Marketing Actions } \\
\hline Advertising & $.127^{* * *}$ & .042 \\
\hline Price & $-2.160 * * *$ & .491 \\
\hline Advertising after start delisting & $.065^{*}$ & .039 \\
\hline Price after start delisting & $.778 * * *$ & .242 \\
\hline \multicolumn{3}{|l|}{ Conflict Characteristics } \\
\hline Publicity & -.001 & .066 \\
\hline Initiator & $.283 * * *$ & .083 \\
\hline \multicolumn{3}{|l|}{ Interaction Effects } \\
\hline Advertising $\mathrm{x}$ publicity & $-.117 * *$ & .053 \\
\hline Price $\mathrm{x}$ publicity & $.871 * *$ & .341 \\
\hline Advertising $\mathrm{x}$ initiator & $-.097^{*}$ & .057 \\
\hline Price $\mathrm{x}$ initiator & $-.753 * * *$ & .280 \\
\hline \multicolumn{3}{|l|}{ Control variables } \\
\hline Elimination size & $.188^{* *}$ & .085 \\
\hline Brand equity & -.046 & .158 \\
\hline Start delisting & $-.335^{* * *}$ & .097 \\
\hline Trend & $.002 * * *$ & .000 \\
\hline Winter & $.075^{* * *}$ & .021 \\
\hline Spring & $.046^{* *}$ & .020 \\
\hline Summer & .018 & .020 \\
\hline Holiday & .012 & .016 \\
\hline Number of observations & 18,845 & \\
\hline
\end{tabular}

*Significant two-tailed result at $10 \%$ significance level

**Significant two-tailed result at $5 \%$ significance level

$* * *$ Significant two-tailed result at $1 \%$ significance level 
Table 2.6: Empirical Results for the Category-Sales Model

\begin{tabular}{|c|c|c|}
\hline & Coefficients & Standard errors \\
\hline \multicolumn{3}{|l|}{ Marketing Actions } \\
\hline Advertising & -.025 & .309 \\
\hline Price & -1.677 & 2.108 \\
\hline Advertising after start delisting & $-1.778 * * *$ & .652 \\
\hline Price after start delisting & $-1.646 * * *$ & .608 \\
\hline \multicolumn{3}{|l|}{ Conflict Characteristics } \\
\hline Publicity & .245 & .253 \\
\hline Initiator & .119 & .087 \\
\hline \multicolumn{3}{|l|}{ Interaction Effects } \\
\hline Advertising $\mathrm{x}$ publicity & -.257 & .248 \\
\hline Price $\mathrm{x}$ publicity & .551 & .496 \\
\hline Advertising $\mathrm{x}$ initiator & $1.842^{* * *}$ & .609 \\
\hline Price $\mathrm{x}$ initiator & $1.130 *$ & .635 \\
\hline \multicolumn{3}{|l|}{ Control variables } \\
\hline Elimination size & -.048 & .146 \\
\hline Brand equity & $-.742 * * *$ & .261 \\
\hline Start delisting & $-.198 * *$ & .097 \\
\hline Trend & $.002 * * *$ & .001 \\
\hline Winter & -.009 & .029 \\
\hline Spring & -.001 & .033 \\
\hline Summer & -.014 & .028 \\
\hline Holiday & .015 & .023 \\
\hline Number of observations & 54,705 & \\
\hline
\end{tabular}

*Significant two-tailed result at $10 \%$ significance level

**Significant two-tailed result at $5 \%$ significance level

$* * *$ Significant two-tailed result at $1 \%$ significance level

\subsubsection{Marketing Actions}

Confirming prior theory, we find a positive effect for relative brand advertising on brand sales $(\beta=.127, p<.01)$, indicating that, in general, increasing brand advertising leads to higher brand sales. Advertising effectiveness for the brand increases in magnitude after the start of the delisting $(\beta=.065, p<.10)$. Relative brand price has a negative effect on brand sales $(\beta=-2.160, p<.01)$, which is in line with extant research as decreasing prices should increase brand sales. However, the effectiveness of price decreases significantly after the start of a delisting $(\beta=.778, p<.01)$. It seems that price discounts are perceived as untrustworthy at times of a conflict delisting. In other words, for the manufacturer, advertising support becomes more effective after a delisting, while decreasing the price becomes less effective. 
In the category sales model, neither relative category advertising $(\beta=-.025, p>$ $.10)$, nor relative category price $(\beta=-1.677, p>.10)$ are significantly different from zero. Interestingly, relative category advertising becomes less effective after the start of the delisting $(\beta=-1.778, p<.01)$, while price changes become more effective $(\beta=-$ 1.646, $p<.01)$. Indeed, the conflict may have hampered the retailer's credibility, leading to a lower advertising effectiveness and a higher price sensitivity. To summarize, in the category sales model, increasing category advertising backfires after the start of a delisting, whereas reducing category prices become more effective after the start of a delisting.

\subsubsection{Conflict Characteristics}

Interestingly, we find a positive effect of the initiator of the conflict in the brand sales model $(\beta=.283, p<.01)$, indicating that the negative performance consequences of a conflict delisting are weakened for the manufacturer if they are the initiator the conflict. Instead of attributing blame to the manufacturer (Folkes 1984), consumers may actually have empathy for the manufacturer that stands up against the powerful retailer. The amount of publicity around the conflict did not significantly affect brand $(\beta=-.001, p>.10)$ or category sales $(\beta=.245, p>.10)$, and initiator did not have a main effect on category sales $(\beta=.119, p>.10)$.

\subsubsection{Interaction Effects between Marketing Actions and Conflict Characteristics}

Advertising and publicity. As hypothesized $\left(H_{1 a}\right)$ advertising becomes less effective for the manufacturer when there is publicity surrounding the conflict $(\beta=-.117, p<.05)$. This finding is consistent with extant literature in which it is posited that negative publicity can damage brand equity and therefore the effectiveness of brand advertising (Goldberg and Hartwick 1990). For the retailer model, although the sign of the interaction is in the expected direction, the coefficient did not reach statistical significance $(\beta=-.257, p>.10)$.

Price and publicity. In contrast to our expectations, we find a positive coefficient for the interaction between price and publicity $(\beta=.871, p<.05)$, indicating that price decreases become less effective when there is publicity surrounding the conflict. Although surprising at first, there will be a high degree of uncertainty present around the degree of unavailability of the product. As a result, consumers will be more sensitive to this uncertainty around the unavailability, which in turn leads to reduced price sensitivity (Erdem, Swait, and Louviere 2002). We do not find significant results for the category sales model $(\beta=.551, p>.10)$.

Advertising and initiator. As expected, advertising becomes less effective for the manufacturer if they are the initiator of the conflict $(\beta=-.097, p<.10)$, thereby providing support for $H_{3 a}$. Moreover, we also find support for $H_{3 b}$, as advertising becomes more effective for retailers when the manufacturer is the initiator of the 
conflict $(\beta=1.842, p<.01)$. These findings corroborate the notion that consumers become suspicious when an initiating company advertises during a conflict delisting, resulting in decreased advertising effectiveness for the initiating party. On the contrary, if a party is not the initiator of the conflict, advertising effectiveness increases. If the manufacturer initiated the delisting, consumers will side with the retailer, making the retailer's advertising more effective.

Price and initiator. Price decreases become more effective for the manufacturer if it is the initiator of the conflict $(\beta=-.753, p<.01)$, supporting $H_{4 a}$. Accordingly, price decreases become less effective for the retailer if the manufacturer initiates the conflict $(\beta=1.130, p<.10)$, supporting $H_{4 b}$. These findings are in line with the reasoning of decreased brand equity when a party initiates the conflict, leading to higher price effectiveness for that particular party and lower price sensitivity for the other party. They further corroborate the notion that consumers value a financial compensation for the inconvenience that the initiator caused.

\subsubsection{Control Variables}

As expected, we find negative sales consequences of conflict delistings for both the manufacturer and the retailer. Consistent with Van der Maelen, Breugelmans, and Cleeren (2017), we find that the negative sales consequences are, over all conflict cases, negative for both manufacturers $(\beta=-.335, p<.01)$ and retailers $(\beta=-.198, p<$ $.05)$. Elimination size has a significant and positive effect on brand sales $(\beta=.188, p<$ $.05)$, indicating that if the entire brand is delisted, sales consequences of the delisting for the manufacturer are weaker. If consumers know in advance that the entire brand is delisted, they might be more likely to switch to a different store to ensure access to the product. For the retailer, we do not find a significant effect for elimination size $(\beta=$ $-.048, p>.10)$. In contrast, brand equity only has a significant impact on category sales $(\beta=-.742, p<.01)$ and not on brand sales $(\beta=-.046, p>.10)$. For category sales, the negative consequences of a conflict delisting are even stronger if a high equity brand is delisted from the shelves (see Van der Maelen, Breugelmans, and Cleeren 2017 for a similar result).

\subsection{ROBUSTNESS CHECKS}

We report several additional model checks to demonstrate the robustness of our results to our modeling choices. We perform robustness checks by 1 ) examining an alternate time period after the delisting, and 2) adding the duration of the delisting as a control variable to our model. 


\subsubsection{Alternate Time-Period}

One of our objectives in the study is to investigate how the effectiveness of marketing actions is altered due to a conflict delisting. We hereby rely on the notion that the presence of a conflict alters consumers' perceptions of a brand, hence spills over to the effectiveness of marketing actions in varying conflict situations. While the start of the delisting is mentioned in the press, the end date of the delisting is not always reported. We therefore used a decision rule (see "Data section") to estimate the end date for all cases.

To assess the robustness of our findings to the decision rule used, we reduced the time after the delisting with $25 \%$ (to 9 months after the start of the delisting). With the exception of the interaction between publicity and advertising, which becomes marginally significant, our results remain robust to this alternate time-period.

\subsubsection{Adding Duration as Control Variable}

We included the duration of the delisting a as control variable to both the brand- and category sales model, as delistings with a longer duration might affect the sales consequences more severely. We operationalized duration as continuous variable which equals zero before the start of the delisting, and indicating the number of weeks the delisting has been going on. After the end of the delisting, duration takes on the maximum value, i.e., the total delisting duration in weeks. Our results show that duration did not significantly influence brand sales or category sales. Our findings for both the brand- and category sales models remain robust.

\subsection{DISCUSSION}

Conflict delistings occur ever more frequently because of a complicated relationship between manufacturers and retailers, and they can seriously damage both parties. In response, managers of both types of companies often increase their advertising support or use price reductions in an attempt to win over the consumer. However, little is known about the effectiveness of these strategies. We therefore examine which of these marketing actions are effective in which conflict situations.

\subsubsection{Theoretical Implications}

Our research contributes to and expands Heider's balance theory (1958) by investigating how the consumer adjusts the balance in case of a disruption in the triadic relationship (i.e., the consumer, and the manufacturer and retailer) and, more importantly, which factors influence these decisions. Once the relationship between the retailer and manufacturer gets disrupted, consumers have to adjust the balance by 
deciding which party to side with: by either purchasing the manufacturer brand at a different store or by choosing a different brand within the retailer. Our study shows that, in line with Van der Maelen, Breugelmans, and Cleeren (2017), both the manufacturer and retailer experience severe sales damages from a conflict delisting. This finding indicates that there is quite some variation in consumer choices; some consumers adjust their balance towards the manufacturer, while others adjust their balance towards the retailer. Our results show that which party the consumer chooses is highly dependent on persuasion techniques (i.e., advertising support and price reductions) employed by the involved companies. More specifically, depending on the contextual factor, some persuasion techniques work better than others in convincing consumers to adjust their balance in the right way. The results therefore emphasize the need for an expansion of the classical balance theory (Heider 1958) into a more nuanced model that takes into account persuasion techniques and contextual factors.

Previous literature alluded to the influence of contextual factors on restoring the direction of the balance (Heider 1958). There is a general belief in marketing that in case of a failure, consumers assign blame to the responsible party (Folkes 1984), which might cause a decrease in purchase intentions and sales. Contrary to the claim, we find that the negative performance consequences of a conflict delisting are actually weakened for the manufacturer if they are the initiator of the conflict. Instead of attributing blame to the manufacturer (Folkes 1984), consumers may actually have empathy for the relatively smaller manufacturer that stands up against the big powerful retailer. In this light, it is surprising at first sight that consumers do not seem to punish the retailer if it is the initiator of the conflict. However, if a retailer initiates a delisting, it is usually to obtain lower prices from the manufacturer, which might result in more attractive consumer prices. These two opposing forces might cancel out, explaining why retailer sales are not affected by the decision to initiate the conflict. The findings regarding publicity are also intriguing. Prior studies have found that negative publicity reduces purchase likelihood and sales (Huang and Chen 2006; Tybout, Calder, and Sternthal 1981; Wyatt and Badger 1984): publicity could lead to increased attention to the conflict and unavailability of the product. We can find an alternative explanation in Berger, Sorenson, and Rasmussen (2010) and Cleeren, Van Heerde and Dekimpe (2012) who argue that the heightened awareness from publicity can cancel out (or even surpass) the negative valence of the message.

The severe damages from a conflict delisting for both parties emphasize the need for appropriate and convincing marketing actions to persuade the consumer to pick one's side in the conflict. To achieve this, it is essential that manufacturers and retailers employ different marketing actions to successfully convince the consumer. Our findings indicate that, given the inherent characteristics of conflict delistings, the effectiveness of marketing actions (i.e., advertising and price) is different from 'normal' situations. Moreover, we conclude that every type of conflict delisting situation requires a different managerial response. This contingency perspective is in line with 
extant research (e.g., Cleeren, Van Heerde, and Dekimpe 2013), who find that the effectiveness of strategic actions is contingent upon the situation at hand. Given the importance of these boundary conditions (Whetten 1989), we discuss these findings and the ties to existing literature in more detail.

The presence of publicity around the conflict delisting significantly changes the effectiveness of the strategic responses. In line with extant research, the presence of publicity decreases the effectiveness of brand advertising. Arguably, the presence of negative publicity, which appears for conflict delistings, reminds the consumers about the negative event (Maehle and Supphellen 2015), hence, decreasing the effectiveness of advertising expenditures. Moreover, starting a wide advertisement campaign while it is widely publicized that the product is widely unavailable might send conflicting messages to the consumer (Kim, Yoon, and Lee 2010), thereby decreasing consumer's trust in the brands' advertisements. For retailers, this is a different story, as the category advertising is typically not about the delisted brand, but offering different brands within the same category. It therefore makes sense that we do not find a significant effect for the retailer.

The presence of publicity also reduces the effectiveness of brand price reductions. There is ample research indicating that negative publicity increases brand awareness (Cleeren, Van Heerde, and Dekimpe 2013), especially since the negative associations might fade away after some time (Van Heerde, Gijsbrechts, and Pauwels 2015). This increases brand equity, which makes price promotions less effective (Erdem, Swait, and Louviere 2002). In contrast, publicity does not change the effectiveness of price reductions for the retailer. Overall, both advertising support and price reductions are not effective tools for retailers to win back consumers in conflict situations surrounded with high publicity.

Both the manufacturer and retailer can be the initiator of the conflict. We find that price sensitivity increases and advertising effectiveness decreases for the manufacturer if it is to blame for the conflict. These findings corroborate with the notion that initiating a conflict hurts the relationship with the consumer, thereby reducing the brand equity of the brand. As a result, advertising effectiveness is reduced (Aaker 1991; Goldberg and Hartwick 1990), while the effectiveness of price reductions increases (Erdem, Swait, and Louviere 2002). For the retailer, we established the opposite effects: when the manufacturer was to blame for the conflict, retailer price promotions become less effective while advertising support has more impact. In this case, the effectiveness of the persuasion techniques are not hampered by an attribution of blame and a related decrease in brand equity.

\subsubsection{Managerial Implications}

The significant interaction effects signify that, in order to make appropriate recommendations, we need to look beyond the main effects, and adapt the use of 
marketing actions depending on the specific conflict situation at hand. The findings can therefore be used to create a marketing dashboard, providing clear managerial recommendations for manufacturers and retailers for each specific conflict situation (as summarized in Table 2.7).

For example, for a situation where the retailer is the initiator of the conflict and where there is no publicity (base scenario), manufacturers are advised to increase their advertising support and keep their prices stable. Retailers, on the other hand, are advised to use price reductions and not engage in increased advertisement support. However, in the opposite case (manufacturer is the initiating party and where there is publicity), we strongly advise manufacturers against increasing their advertising support, as it might even backfire. In contrast, in this situation, retailers are highly recommended to increase their category advertising to alleviate potential damages. The marketing dashboard indicating the optimum managerial response for each situation can be found in Table 2.7.

Table 2.7: Marketing Dashboard: How to Respond to Conflict Delistings

\begin{tabular}{|c|c|c|c|c|c|c|}
\hline \multicolumn{3}{|c|}{ Conflict Situation } & \multicolumn{2}{|c|}{ Recommendations for Brand } & \multicolumn{2}{|c|}{ Recommendations for Retailer } \\
\hline \multirow[b]{2}{*}{ Scenario } & \multirow[b]{2}{*}{ Initiator } & \multirow[b]{2}{*}{ Publicity } & \multicolumn{2}{|l|}{ Advertising } & \multicolumn{2}{|l|}{ Advertising } \\
\hline & & & Support & Price Reductions & Support & Price Reductions \\
\hline $\begin{array}{l}1 \\
\text { (base) }\end{array}$ & Retailer & No & $\begin{array}{l}\text { Increase brand } \\
\text { advertising, } \\
\text { effective } \\
\text { marketing action }\end{array}$ & $\begin{array}{l}\text { Keep brand price, } \\
\text { less effective } \\
\text { than pre-conflict }\end{array}$ & $\begin{array}{l}\text { Keep category } \\
\text { advertising, } \\
\text { not effective at all }\end{array}$ & $\begin{array}{l}\text { Reduce brand } \\
\text { price, effective } \\
\text { marketing action }\end{array}$ \\
\hline 2 & Retailer & Yes & $\begin{array}{l}\text { Do not increase } \\
\text { brand advertising, } \\
\text { less effective than } \\
\text { base case }\end{array}$ & $\begin{array}{l}\text { Keep brand price, } \\
\text { even less } \\
\text { effective than } \\
\text { base case }\end{array}$ & $\begin{array}{l}\text { Keep category } \\
\text { advertising, same } \\
\text { as base case }\end{array}$ & $\begin{array}{l}\text { Reduce brand } \\
\text { price, } \\
\text { same as base case }\end{array}$ \\
\hline 3 & Manufacturer & No & $\begin{array}{l}\text { Do not increase } \\
\text { brand advertising, } \\
\text { shift of blame }\end{array}$ & $\begin{array}{l}\text { Reduce brand } \\
\text { price, offer } \\
\text { compensation for } \\
\text { conflict }\end{array}$ & $\begin{array}{l}\text { Increase category } \\
\text { advertising, more } \\
\text { effective than } \\
\text { base case }\end{array}$ & $\begin{array}{l}\text { Do not reduce } \\
\text { category price, } \\
\text { less effective than } \\
\text { base case }\end{array}$ \\
\hline 4 & Manufacturer & Yes & $\begin{array}{l}\text { Do not increase } \\
\text { brand advertising, } \\
\text { might backfire }\end{array}$ & $\begin{array}{l}\text { Decreasing price } \\
\text { might be } \\
\text { attractive, } \\
\text { depending on } \\
\text { opposing forces }\end{array}$ & $\begin{array}{l}\text { Increase category } \\
\text { advertising, } \\
\text { effective } \\
\text { marketing action }\end{array}$ & $\begin{array}{l}\text { Do not reduce } \\
\text { category price, } \\
\text { not effective }\end{array}$ \\
\hline
\end{tabular}

\subsubsection{Limitations and Directions for Future Research}

Although our research provides interesting insights, the present study has several limitations which present suggestions for future research. First, while our study examines manufacturer and retailer actions by looking into price and advertising, we were not able to observe what takes place in-store during the delisting. Next to pricing and advertising, the retailer has the opportunity to use in-store displays to inform the 
consumer about the delisting. The display information could merely contain information about the occurrence of the delisting, but can also be used to suggest alternative brands in the category, such as the retailers' private label brands or other national brands. Although we already have some information about the effectiveness of in-store displays in a regular online out-of-stock context (Breugelmans, Campo, and Gijsbrechts 2006), in-store shelf information might work differently in a conflict setting, and could be an effective marketing action to alleviate damages. In addition, retailers control the instore shelf allocation during a delisting. Retailers can make use of this opportunity to allocate more shelf space to either their private label brand or other national brands. Future research could look into these in-store marketing actions that retailers have at their disposal, for example by means of laboratory or natural field experiments.

Second, we focus on performance consequences in terms of brand and category sales, which provide useful and practical insights into our focal research question: the effectiveness of tactical actions. Due to data unavailability, we could not investigate the total damage in store revenue from the delisting. Consequences on the store level might be even more severe for the afflicted retailer, when consumers switch their entire shopping basket to a competing retail store. Future research could therefore examine the consequences of a conflict delisting on a retailer's total store sales.

Third, it would be interesting to examine the effects of conflict delistings and the accompanied managerial actions in the long run. Conflict delistings may have an impact on the long-term relationship between manufacturers and retailers. For retailers, this might manifest itself in reducing shelf space for other products of the manufacturer, a lower inclination to introduce new product innovations from manufacturers, or decreased promotional support for the manufacturer's products. On the other hand, manufacturers have the option to increase distribution at other channels: they might strengthen ties with other retailers, or, even start selling directly to the end-consumer by means of direct online stores or fully-owned brick and mortar stores.

Fourth, in line with previous literature (e.g., Geyskens, Steenkamp, and Kumar 1999), we assume conflicts and the resulting publicity to be of negative valence, as the publicity surrounding the delisting reminds consumers of the unavailability of the product. Although in contrast to the often assumed objective role of publicity (Balasubramanian 1994), reporters might decide to side with either the manufacturer or the retailer, leaving the valence of the publicity unclear. Future research could further investigate the role of publicity in conflict delistings, and more specifically, use text-mining techniques to investigate the valence of the messages.

In summary, our study offers important theoretical and managerial insights into the topic of conflict delistings. We offer recommendations to both retailers and manufacturers on how to strategically manage such a power conflict, giving them both the opportunity to fight for their customers. 

Chapter

The Market Valuation of Conflict Delistings 



\subsection{INTRODUCTION}

Conflicts are inevitable in any marketing channel relationship (Gaski 1984; Koza and Dant 2007). Especially in manufacturer-retailer relationships conflicts are quite prominent, due to often conflicting objectives (Rosenberg and Stern 1971) between the two powerful parties. While retailers are under increasing pressure to keep prices at an all-time low (The Telegraph 2016), it is in the manufacturers' interest to negotiate high wholesale prices from the retailer (Geylani, Dukes, and Srinivasan 2007). When manufacturers and retailers refuse to compromise, they often revert to removing products from supermarket shelves until the conflict is resolved (Sloot and Verhoef 2008). This is commonly referred to as conflict delistings (Van der Maelen, Breugelmans, and Cleeren 2017). Recent examples include UK retailer Tesco pulling 25 Coca-Cola products from the shelves in response to a price increase by Coca-Cola (The Grocer 2015) and German manufacturer Dr. Oetker ceasing deliveries to retailer Real in response to the desired changes in delivery terms by Real (dpa-AFX 2015).

Conflict delistings might influence firm value through its effects on profit margins, changes in the manufacturer-retailer relationship, and even negotiations with other marketing channel partners. However, it is currently unclear when the negative or positive effect of a conflict delisting will prevail. Anecdotal evidence reveals that retailer Delhaize lost 3.3\% in stock price due to a delisting announcement (De Morgen 2009; De Standaard 2009). In contrast, retailer Ahold gained 0.5\% from a conflict delisting announcement (Het Financieele Dagblad 2006). Therefore, there is a clear need to unify these different effects and to investigate the total impact of a conflict delisting for both manufacturers and retailers on firm value.

Despite their frequent occurrence and large potential consequences, academic research on conflict delistings is scarce. Both academics and practitioners therefore lack knowledge on the firm-level performance consequences of conflict delistings. This research contributes to the extant literature in two ways. First, we contribute to the literature on coercive power (i.e., punishments). The mere threat of coercive power use increases the number of conflicts in the channel and subsequently results in reduced channel satisfaction, trust, and commitment (for an overview see Gaski 1984 or Geyskens, Steenkamp, and Kumar 1999). However, these performance metrics are disaggregate indicators and may not be as informative an aggregate metric. The aforementioned measures, for example, do not account for the impact of consumer reactions, changes in the manufacturer-retailer relationship and future negotiations between these two focal parties, (future) negotiations with other channel partners, and profit margins. In addition, these studies are mainly based upon survey research and self-assessed evaluations, and it is unclear how these translate into objective, economic measures. A notable exception is the research by Van der Maelen, Breugelmans, and Cleeren (2017), who investigate consumer reactions to conflict delistings and demonstrate that conflict delistings harm the market shares of both the 
manufacturer and the retailer. However, they only capture the consumer effect on conflict delistings, rather than the total effect of a conflict delisting on the firm. To investigate the overall impact of conflict delistings on firm value, we rely on shareholder value as our performance metric. Shareholder value is particularly suitable since a change in stock prices is an unbiased reflection of changes in all expected future cash flows of the firm (Chaney, Devinney, and Winer 1991). As such, shareholders will react negatively to announcements in which they expect future cash flows to decrease and positively for an expected increase in future cash flows (Raassens, Wuyts, and Geyskens 2012). Thus, event studies allow for an inference of cause and effect in a quasi-experimental setting (Srinivasan and Hanssens 2009).

Second, we study how the performance implications of conflict delistings may differ across different conflicts and firms. Extant literature has hinted at cross-case variability between different (brand) delisting situations (Sloot and Verhoef 2008; Van der Maelen, Breugelmans, and Cleeren 2017). We therefore theorize and test in which conflict situations the performance consequences are more or less severely affected by conflict delisting announcements. To explain the variability between different conflict delistings, we draw on the literature on threats (i.e., Gielens et al. 2008). Based on Gielens et al.'s (2008) existing framework, we distinguish between 1) the seriousness of the conflict delisting and 2) the capacity to withstand the negative consequences of a conflict delisting. Both are multifaceted constructs, meaning that we utilize multiple dimensions for both the seriousness of the delisting (i.e., elimination size and publicity) and the capacity to withstand the negative consequences of the delisting (i.e., initiator, firm size of the focal firm and its opponent), thereby giving a well-rounded picture into the variety of different conflict delisting situations. By analyzing the impact of conflict delistings on firm value, we are able to formulate empirical generalizations. Identifying empirical generalizations is critical for managers who look at generalizations for guidelines for action (e.g., Bass and Wind 1995). Furthermore, by identifying the factors that distinguish harmful conflict delistings from advantageous ones, we further advance theory in the field by identifying relevant boundary conditions (cf. Whetten 1989).

To investigate the impact of conflict delistings on firm value and to examine which conflict situations cause more or less harm to the firm, we composed a sample of 69 conflict delistings that occurred between 2000 and 2016 in Belgium, Germany, The Netherlands, and the UK. We use the event study methodology, with the change in shareholder value around the conflict delisting announcement dates as our performance measure. The results show that, on average, conflict delistings are detrimental for firms and result in a $.66 \%$ decrease in firm value. However, there is considerable variation in the performance implications of conflict delistings across firms, as in almost half of the cases, conflict delistings even resulted in positive performance evaluations. In line with our expectations, we find that the more serious a conflict delisting (i.e., when the conflict entails more delisted brands and the conflict receives more publicity), the more negative are its performance implications. 
Additionally, the results show that if a firm has a high capacity to protect itself against negative consequences (i.e., when the firm is the initiator of the conflict delisting or is larger in size), the impact of conflict delistings on firm value will be less negative.

The remainder of this chapter is organized as follows. First, we review the literature on the performance implications of coercive power, present the conceptual framework, and discuss the hypotheses. Next, we outline the event study methodology, describe the data, and present the results. Finally, we discuss the theoretical and managerial implications in the discussion section, and provide worthwhile avenues for future research.

\subsection{PERFORMANCE IMPLICATIONS OF COERCIVE POWER: A LITERATURE OVERVIEW}

Conflict delistings, defined as the temporary delisting of products due to a conflict, are a result of power battles in which one party decides to exercise its coercive (i.e., punitive) power to pressure the other party into complying with its demands.

Despite its academic and practical relevance, literature on conflict delistings is surprisingly scarce. One notable exception of a recent study investigating conflict delistings, is a study by Van der Maelen, Breugelmans, and Cleeren (2017), who investigate the impact of conflict delistings on consumer reactions. Using a single conflict case, they conclude that conflict delistings severely harm the market shares of both manufacturers and retailers.

Because conflict delistings have been under-researched, we take a look at a related literature stream, namely the area of coercive power (i.e., punishments). Conflict delistings can be considered as a punitive action by one of the channel members, and can therefore be regarded as a form of coercive power. The literature on coercive power is mainly characterized by survey research, in which parties self-assess the relationship with their channel partner. This line of research mainly focusses on coercive power as a dimension or driver of channel power and conflict (e.g., Gaski 1984) and its consequences on relationship satisfaction (e.g., Geyskens, Steenkamp, and Kumar 1999; Skinner, Gassenheimer, and Kelley 1992). More specifically, Gaski $(1984$, p.22) concludes that "the imposition of harsh sanctions upon channel members (i.e., exercised coercive sources of power) seems certain to cause dissatisfaction and conflict." Furthermore, coercive power sources are positively correlated with conflict (Skinner, Gassenheimer, and Kelley 1992) and negatively related to satisfaction within the marketing channel (Hunt and Nevin 1974).

Furthermore, conflicts are known to affect channel performance. For example, Lusch (1976) reveals that perceived channel conflict negatively affects operating performance. In other words, firms who indicate that they frequently disagree with their channel member are typically characterized by a lower operating performance. In 
addition, conflict also decreases non-economic satisfaction because "channel members do not appreciate interactions with parties that threaten them" (Geyskens, Steenkamp, and Kumar 1999, p. 277). In the long term, this decreased non-economic satisfaction leads to reduced trust and commitment in the channel relationship (Geyskens, Steenkamp, and Kumar 1999). Furthermore, conflicts negatively affect cooperation and satisfaction, as they decrease channel efficiency and hinder the realization of channel goals (Skinner, Gassenheimer, and Kelley 1992).

In sum, research on the impact of coercive power (such as conflict delistings) shows that coercive power negatively influences the relationship between two channel members. However, this research is mainly based on subjective and self-assessed evaluations, in which it is not clear how these translate into objective, economic measures. In addition, the surveys are often collected at one point in time, making causal inference difficult. In this study, we use an objective measure to shed light on the impact of conflict delistings, and use a quasi-experimental setting to allow for the inference of cause and effect (Srinivasan and Hanssens 2009). Accordingly, we do not only take consumer reactions into account, but rather provide insights into the overall performance implications of conflict delistings.

\subsection{CONCEPTUAL FRAMEWORK}

The impact of a conflict delisting on firm value of the involved manufacturer and retailer can be considered ambiguous, as it may invoke either negative or positive investor responses (as depicted in the Delhaize and Ahold examples earlier). On the negative side, conflict delisting may impact firm value given its impact on three distinctive performance indicators.

First, we expect conflict delistings to impact firm value through its negative impact on consumer responses. Conflict delistings can cause major short-term sales losses for both parties involved. Indeed, conflict delistings are known to cause severe short-term market share losses for both manufacturers and retailers (Van der Maelen, Breugelmans, and Cleeren 2017), due to consumers switching to alternative brands within the store and consumers switching between stores, respectively. These shortterm effects might persist in the long-term if the consumers' switch is permanent, i.e., if they do not switch back to their original brand or retailer after the end of the delisting.

Second, conflict delistings can be considered as a coercive power source, and might therefore decrease satisfaction, trust, and cooperation between the manufacturer and retailer. Therefore, a conflict delisting may not only influence the current negotiation process, but may also affect the outcomes of future negotiations after the conflict is resolved (Sloot and Verhoef 2008), thereby causing harm to both manufacturers and retailers. More specifically, as manufacturers depend on retailers as they make the 
final decision on which brands to carry in their assortment (Dukes, Geylani, and Srinivasan 2009), a retailer may retaliate in three different ways. First, the retailer can decide to reduce the number of innovations carried in the assortment, thereby acting as a crucial influence on the innovation success of new products of the manufacturer (Lamey et al. 2014). Second, retailers can reduce the manufacturer's shelf space or place the products in a sub-optimal place on the shelf, a factor that is proven to be crucial for manufacturer's sales (Drèze, Hoch, and Purk 1994). Third, retailers could reduce promotional support of the manufacturer's brands, impacting the manufacturer's performance (Gedenk, Neslin, and Ailawadi 2006). Manufacturers have possibilities to retaliate as well. In particular, the manufacturer can opt to increase distribution via different channels, or even expand or establish a direct channel (referred to as encroachment), bypassing the retailer. Encroachment can harm a retailer, as it can reduce the demand for a retailer's products (e.g., Arya, Mittendorf, and Sappington 2007; Liu and Zhang 2006). Moverover, carrying the manufacturer's assortment is vital for retailers, as the manufacturers' often popular national brands generate store traffic (Shankar, Carpenter, and Farley 2012).

Third, a conflict delisting might impact outcomes of future negotiations with other channel partners. A conflict delisting may reinforce the negative image of the dominant big-box retailer, squeezing profit margins from suppliers (Draganska, Klapper, and Villas-Boas 2010). In a similar vein, the manufacturers' image at other retailers may suffer a blow.

Although counter-intuitive at first sight, conflict delistings may also positively impact firm performance, in two different ways. First, a conflict delisting may increase a firm's profitability if it reaches an agreement that is beneficial for the firm (Sloot and Verhoef 2008). If a firm is expected to 'get what it wants' out of the conflict delisting and effectively wins the negotiation process, the negative effects (e.g..., sales losses) may be offset due to a vast increase in future cash flows. For example, if a relisting occurs according the demanded conditions (e.g., higher profit margins or enhancement of other buying conditions) the conflict may be regarded as a "shortterm pain, long-term gain" (Sloot and Verhoef 2008). The investors will in this case expect an increase in future cash flows, which will be reflected in the stock price.

Second, conflict delistings may improve the negotiation position and bargaining power of the firm in the retailing landscape. A delisting may be a reflection of a zerotolerance negotiation policy, emphasizing its strength and dominance in the negotiation process. This signal can serve as a warning, not only to the conflicting party, but also to other negotiation partners in the market. In the long run, a conflict delisting might result in an enhanced bargaining position, which in turn, results in a more profitable business model (Draganska, Klapper, and Villas-Boas 2010).

In sum, conflict delistings could potentially lead to both negative and positive firm evaluations. While the outcomes of a conflict delisting can be considered ambiguous, we expect that the negative implications will outweigh the positive ones. Research in 
economics indicates that investors are distinctively more sensitive to losses than gains, due to loss aversion (e.g., Benartzi and Thaler 1995; Chen, Ganesan, and Liu 2009; Tversky and Kahneman 1991). We therefore expect a negative impact of conflict delistings on firm value, caused by its harmful impact on consumer reactions, the manufacturer-retailer relationship (satisfaction, trust, and cooperation), and future negotiations with other channel partners. We hypothesize:

H1: Conflict delistings have a negative impact on firm value.

\subsubsection{Cross-Sectional Variation}

Previous literature and anecdotal evidence have alluded to cross-case variability between different (conflict) delisting situations (Sloot and Verhoef 2008; Van der Maelen, Breugelmans, and Cleeren 2017). Consequently, we argue for a contingency perspective to investigate the direction and magnitude of the stock market reaction and hypothesize in which conflict delisting situations conflict delistings negatively or positively affect firm value. To explain the cross-sectional variation in investor responses, we build on the conceptual framework developed by Gielens et al. (2008), who investigate investor responses in the context of a threat or disruption in the market, in their case by examining the impact of a Wal-Mart entry on the incumbent retailers. In a similar vein, conflict delistings pose a threat towards the manufacturerretailer relationship, and are a disruption of the status-quo. Therefore, in line with Gielens et al. (2008), we expect the performance implications of conflict delistings to be contingent on 1) the seriousness of the conflict delisting and 2) the capacity of the focal firm to withstand the negative consequences of the conflict delisting. For example, if the seriousness of the delisting is low and the firm's capacity to withstand the negative consequences of the delisting is high, the positive factors (i.e., possible increase in profit, stronger future bargaining position) may prevail the negative factors (i.e.., loss in sales, lower satisfaction, trust, and cooperation, impaired negotiations with other channel partners). In contrast, if the conflict delisting is very severe while the firm lacks the capacity to withstand the negative consequences of the conflict delisting, the negative factors are likely to predominate the positive ones.

The seriousness of the conflict delisting and the capacity to withstand the negative consequences of a conflict delisting are multifaceted constructs, meaning that specific components can be distinguished within the seriousness of the conflict delisting and the capacity to withstand the negative consequences of the conflict delisting. This provides a framework in which a wide array of stock price reactions are possible. Figure 3.1 summarizes our conceptual framework, depicting these components and the direction of the expected contingent effects. 


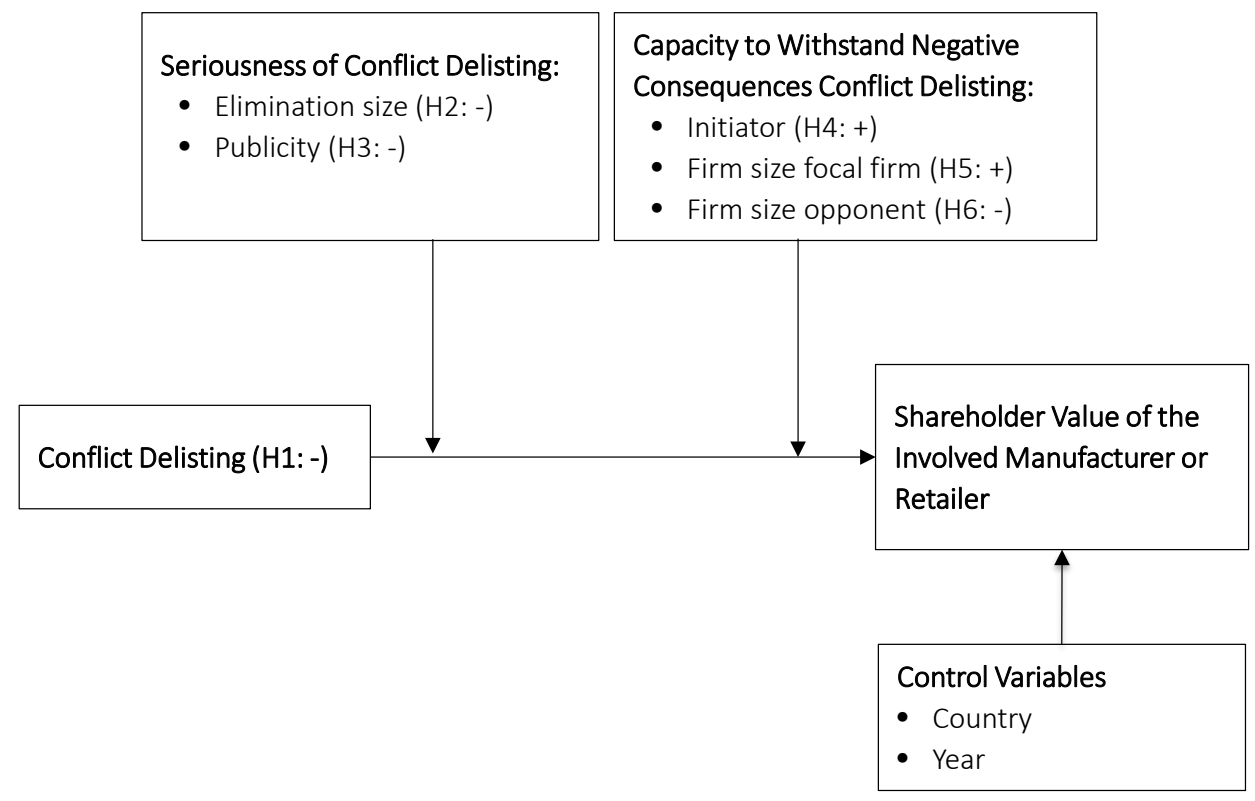

Figure 3.1: Conceptual Framework

\subsubsection{Seriousness of the Conflict Delisting}

A conflict delisting is likely to be more serious when the size of the conflict is large (i.e., when a lot of brands are delisted) and when many stakeholders (e.g., consumers, other parties) are aware of the conflict delisting (i.e., when the conflict delisting is surrounded by a lot of publicity). A more serious delisting not only leads to stronger sales responses from consumers, it more severely disrupts the manufacturer-retailer relationship, and might damage the relationship with other negotiation parties.

Elimination size. Elimination size refers to the number of brands that were removed from the shelves due to the conflict delisting. Elimination size will affect shareholder evaluations of the conflict delisting in two ways. First, conflict delistings involving a higher elimination size will lead to more severe sales consequences. For each brand that is unavailable during the conflict delisting, consumers have to decide whether to switch to a different brand, category, store, or to postpone or cancel the purchase altogether (e.g., Campo, Gijsbrechts, and Nisol 2000; Emmelhainz, Stock, and Emmelhainz 1991; Sloot, Verhoef, and Franses 2005). When a large number of brands are delisted, the forgone product sales can accumulate very rapidly into substantial sales and market share losses.

Second, a higher elimination size might be a bad omen for investors. Indeed, something could be fundamentally wrong in the manufacturer-retailer relationship. While a minor delisting may indicate a small disagreement or nudge towards compliance, a large elimination size indicates that a full-on war has occurred between 
the two parties. Structural damages in the manufacturer-retailer relationship can decrease future cash flows, due to the aforementioned long-term repercussions (e.g., increased distribution via other distribution channels, decrease in product innovations, loss of promotional support, undesirable shelf space) (Geyskens, Kumar, and Steenkamp 1999; Skinner, Gassenheimer, and Kelley 1992). Investors are likely to react immediately to this information which places future earnings and cash flows at risk. Thus, we hypothesize:

$\mathrm{H} 2$ : The greater the elimination size of the conflict delisting, the more negative is the impact of conflict delistings on firm value.

Publicity. Given its negative valence (Geyskens, Steenkamp, and Kumar 1999), a conflict is regularly surrounded by negative publicity and press. We therefore consider publicity in conflict situations as negative publicity, as it places emphasis on the unavailability of the involved products and makes consumers, investors, and other stakeholders aware of the conflict situation. Based on information processing theory, we know that this increased awareness may considerably influence a consumer's brand attitude and choice (Baker 1999; Hsu and Lawrence 2016). In addition, consumers tend to place trust in messages reported in independent media, due to its high source credibility (e.g., Eisend and Küster 2011; Lord and Putrevu 1993). As a result, if negative publicity surrounding the conflict delisting is high, it will have a negative impact on sales (e.g., Basuroy, Chatterjee, and Ravid 2003; Chevalier and Mayzlin 2006; Freedman, Kearney, and Lederman 2012).

In support of our premise that conflict delistings surrounded by negative publicity will lead to lower shareholder value, we turn to two recent studies that have investigated investor responses to negative publicity (Hsu and Lawrence 2016; Van Heerde, Gijsbrechts, and Pauwels 2015). Both studies found support for a negative relationship between the volume of publicity and shareholder value. They argue that the increased attention around a negative event (i.e., product recall and price war, respectively) makes investors uneasy about the firm's future cash flow expectations. As such, widely publicized conflict delistings may be regarded as trouble by investors since it may reduce discounted future cash flows, which are reflected in stock market returns. It is plausible that we find these negative effects in our study as well, for two reasons.

First, in a product unavailability context, knowledge institute EFMI (2000) investigated the effect of out-of-stock (OOS) announcements on consumer reactions. They found that categories without out-of-stock announcements were rated significantly higher than categories with announcements. Indeed, out-of-stock announcements "heighten awareness of the OOS among consumers, making it more obvious and probably creating more dissatisfaction" (Verhoef and Sloot 2006, p. 295). The authors therefore strongly advise against using messages that emphasize the 
unavailability to consumers, which coincides with the underlying consequence of the negative publicity surrounding a conflict delisting.

Second, in addition to the effect on consumer reactions, publicity can affect other channel partners, such as a firm's suppliers or other distributors. High levels of negative publicity are likely to reach and inform a firm's other channel partners of the conflict, leading to reputational damages of the conflicting parties, i.e., the involved manufacturer and retailer. For example, suppliers often feel threatened by the growth and efficiency gains of powerful retailers (Dukes, Gal-Or, and Srinivasan 2006). A retailer involved in a conflict delisting may further support this image of a powerful retailer, and disrupts the relationship with other channel partners. Along the same line of reasoning, large food manufacturers are often regarded as "driving a hard bargain" by their, typically smaller, suppliers (The Telegraph 2015). Additionally, a conflict delisting may damage a manufacturer's reputation at other retailers, which may hamper (future) negotiations with these retailers. A conflict delisting may therefore negatively alter the relational dynamics between the retailer and its other manufacturers, the manufacturer and its suppliers, and the manufacturer and other retailers. In sum, we expect the following:

H3: The greater the amount of publicity surrounding the conflict delisting, the more negative is the impact of conflict delistings on firm value.

\subsubsection{Capacity to Withstand the Negative Consequences of Conflict Delistings}

Apart from differences in the seriousness of the delisting, we also expect the capacity to withstand the negative consequences of the conflict delisting to have an effect. In general, the lower the firm's capacity to withstand the negative consequences of a delisting, the more negative the performance consequences will be. Johnson and Tellis (2008) argue that firms differ from each other mainly in two aspects, namely the firm strategy and the key resources. As such, to capture the possible variations in firms in the capacity to withstand the negative consequences of a conflict delisting, we differentiate between 1 ) whether the focal firm is the initiator of the delisting (i.e., as a reflection of the firm's strategy), and 2) the firm size of the focal firm and its opponent (i.e., as indicators of key resources). First, initiating a conflict delisting is a strategic firm choice, and indicative of a firm's strategy in the negotiation process. Second, firms who have large financial resources are better equipped to withstand a conflict delisting, especially if the opponent has little resources.

Initiator. A conflict delisting can be initiated by either the manufacturer or the retailer. The manufacturer can decide to cease all deliveries to the retailer, while the retailer can refuse to stock the manufacturer's brands on the shelves or cease to place orders from the manufacturer. Initiating a conflict delisting may signal towards investors that the firm is confident and optimistic about the outcomes of the conflict delisting. Due to the information asymmetry between the firm and the investors 
(Connelly et al. 2011), firms might use the opportunity to signal its true quality to investors, in our case, by initiating a conflict delisting. This is in line with research on product-harm crises, where non-voluntary recalls are associated with negative shareholder value while voluntary recalls are not (Davidson and Worrel 1992). In addition to providing a signal of strength towards investors, initiating a delisting also serves as a warning sign to future negotiation partners. As such, initiating a conflict delisting may be positive, as it may provide a signal that they are "a market player to reckon with." Furthermore, arguably, a firm only initiates a conflict delisting if they expect to have the upper hand and come out of the negotiations better off financially. While initiating a conflict delisting might signal strength, being at the receiving end of a conflict delisting may signal a position of weakness. After all, the initiating firm is overtly taking strategic actions to pressure the non-initiating firm into complying. We therefore expect more favorable consequences for shareholder value if the focal firm is the initiator of the conflict delisting.

H4: If the focal firm is the initiator of a conflict delisting, the impact of conflict delistings on firm value is less negative.

Firm size focal firm. Firm size is a primary indicator of a firm's tangible resources (Audia and Greve 2006), including a firm's financial (Contractor, Kumar, and Kundu 2007; Raassens, Wuyts, and Geyskens 2014) and human resources (Datta, Guthrie, and Wright 2005), and its management expertise (Cui and Lui 2005). Large firms have more financial resources than smaller firms (Johnson and Tellis 2008), and are therefore better equipped to proactively engage in strategic responses (Gielens et al. 2008), such as increased advertising support or price promotions, to mitigate negative consequences of conflict delistings. In addition, due to their larger financial buffer (Chen, Ganesan, and Liu 2009; Hsu and Lawrence 2016), larger firms are less vulnerable to small disruptions in their revenue streams. In general, they are more capable of sustaining periods of negative performance (Johnson and Tellis 2008), and are more likely to survive than smaller firms (Stuart 2000). Additionally, large firms have more financial resources to hire experienced employees and invest in training employees to excel at negotiations. The resulting negotiation skills, patience, and risk tolerance increase the bargaining power of a party (Draganska, Klapper, and VillasBoas 2010), which will positively reflect the financial outcome of the negotiations. Indeed, Draganska, Klapper, and Villas-Boas (2010) find that a larger firm size, both for manufacturers and retailers, is associated with more bargaining power. Consequently, investors may anticipate that the larger firm will "win" the negotiations, leading to more future cash flows. In contrast, smaller firms are generally unequipped to handle and recover from a disruption, such as the unavailability of products due to conflict delistings, because of to the strong dependence of smaller firms on the success of all of its products (Thirumalai and Sinha 2011). In sum, the larger the firm size, the greater the firm's capacity to withstand the negative consequences of a conflict delisting. 
H5: If the firm size of the focal firm is large, the impact of conflict delistings on firm value is less negative.

Firm size opponent. Bargaining power is "not an inherent characteristic of a firm but depends on the negotiation partner" (Draganska, Klapper, and Villas-Boas 2010, p. 57). Firm size should therefore not be considered in isolation, as the outcome of the conflict resolution will depend on the size of the opponent as well. In line with our earlier discussion on the focal firm's size, a larger opponent will have more access to financial and human resources. A large-sized opponent will therefore reduce the focal firm's capacity to withstand the negative consequences of the conflict delisting, as it will be more difficult for the focal party to "win" the negotiation process. We therefore hypothesize:

H6: If the opponent's firm size is higher, the impact of conflict delistings on firm value is more negative.

\subsection{EVENT STUDY METHODOLOGY}

To examine the effect of conflict delistings on shareholder value, we use the event study methodology. Event studies have a long tradition in marketing and are particularly suitable for investigating shareholder responses to announcements of firm events. They have been used to examine investor responses to a wide variety of announcements including Internet channel additions (Geyskens, Gielens, and Dekimpe 2002), innovation projects (Sood and Tellis 2009), outsourcing agreements (Raassens, Wuyts, and Geyskens 2012), and product recalls (Chen, Ganesan, and Liu 2009; Hsu and Lawrence 2016).

The event study methodology is based on the semi-strong form of the efficient market hypothesis, which states that stock prices accurately reflect all publicly available information (Fama 1970). In other words, "a company's stock price reflects the market's expectations of the discounted value of all future cash flows expected to accrue to the firm" (Geyskens, Gielens, and Dekimpe 2002, p. 108). This implies that if new information is made public, it will be immediately incorporated into the stock price due to investors buying or selling their stocks. ${ }^{9}$ Thus, a change in stock prices is an unbiased reflection of changes in the expected future cash flows of the firm (Chaney, Devinney, and Winer 1991). In line with the semi-efficient market hypothesis, the reactions of shareholders to a conflict delisting announcement will reflect all future cash flows resulting from the conflict delisting.

\footnotetext{
${ }^{9}$ To isolate the effect of a conflict delisting announcement, cases in which confounding information is published on the event day (e.g.., profit statements) are excluded from the sample (cf. Hsu and Lawerence 2016).
} 
To observe shareholder reactions to firm events, the event study methodology relies on daily (i.e., trading days) abnormal stock returns. To obtain the abnormal returns, we first estimate the expected return around the event day (i.e., the return that would be expected if the event had not taken place) using the market model, based on an estimation period well before the event. We then calculate the abnormal returns, defined as the difference between this expected return and the observed return.

We first calculate the observed returns $R_{i t}$, defined as the percentage change in stock price of case i between day t-1 and day t: ${ }^{10}$

$$
R_{i t}=\frac{P_{i t}-P_{i t-1}}{P_{i t-1}}
$$

$R_{\text {it }}$ reflects the investors' updated beliefs about future earnings due to information that became available between day $t-1$ and day $t$. Next, we estimate $E\left(R_{\text {it }}\right)$, the return that would be expected if the event had not taken place. Following Geyskens, Gielens, and Dekimpe (2002) and Hsu and Lawrence (2016), we use the market model to estimate $E\left(R_{i t}\right)$. In the market model, we regress a company's observed return $\left(R_{i t}\right)$ on the market index return in the country the company is listed in $\left(R_{m t}\right)$ over an estimation period of 250 to 30 days preceding the event (cf. Geyskens, Gielens, and Dekimpe 2002; Raassens, Wuyts, and Geyskens 2012, 2014):

$$
R_{i[t-250: t-30]}=\alpha_{i}+\beta_{i} R_{m[t-250: t-30]}+\varepsilon_{i[t-250: t-30]}
$$

We refer to Table 3.1 for an overview of the market indices per country. We subsequently use the obtained firm-specific intercepts $\hat{\alpha}_{i}$ and estimated firm-specific slope coefficients $\hat{\beta}_{i}$ from equation 2 to estimate $E\left(R_{i t}\right)$ :

$$
E\left(R_{i t}\right)=\hat{\alpha}_{i}+\hat{\beta}_{i} R_{m t}
$$

The difference between the actual return $R_{i t}$ and the expected return $E\left(R_{i t}\right)$ is a measure of the abnormal return $\mathrm{AR}_{\mathrm{it}}$ :

$$
A R_{i t}=R_{i t}-E\left(R_{i t}\right)=R_{i t}-\left(\hat{\alpha}_{i}+\hat{\beta}_{i} R_{m t}\right)
$$

where $A R_{\text {it }}$ provides an unbiased estimate of the future earnings generated by the event (Raassens, Wuyts, and Geyskens 2012), i.e., conflict delistings.

\footnotetext{
${ }^{10}$ More specifically, a case (i) refers to one firm that is involved in a conflict delisting.
} 
Table 3.1: Market Indices

\begin{tabular}{ll}
\hline Country & Market Index \\
\hline Netherlands & AEX Index \\
Belgium & BEL20 \\
United Kingdom & FTSE100 \\
Germany & DAX 30 \\
Denmark & OMX Copenhagen \\
France & CAC 40 \\
United States & NYSE Composite, NASDAQ Composite \\
Japan & TOPIX \\
\hline
\end{tabular}

To account for possible information leakage before the event day and the possibility that not all information is completely disseminated on the event day (McWilliams and Siegel 1997), the abnormal returns are aggregated over an event window $\left[-t_{1}, t_{2}\right]$ into a cumulative abnormal return (CAR). The CAR makes it possible to draw overall inferences on the expected performance of the event for each individual firm. The CAR is calculated as follows:

$$
C A R_{i}\left[-t_{1}, t_{2}\right]=\sum_{t=-t_{1}}^{t_{2}} A R_{i t}
$$

Because the event study is conducted over $\mathrm{N}$ events, this CAR can be averaged into a cumulative average abnormal return (CAAR):

$$
C A A R\left[-t_{1}, t_{2}\right]=\frac{\sum_{i=1}^{N} C A R_{i}\left[-t_{1}, t_{2}\right]}{N}
$$

Thus far, the length of the event window $\left[-t_{1}, t_{2}\right]$ is not known. To assess the extent of information leakage and dissemination, and thus the length of the event window, the most significant CAAR from several calculated CAARs for different event windows is selected (for a similar procedure, see e.g., Chaney, Devinney, and Winer 1991; Geyskens, Gielens, and Dekimpe 2002). To test the significance of the CAARs we use Patell's (1976) statistic. First, the daily abnormal returns are standardized by the standard errors from equation 2. Subsequently, the z-values of the standardized CAARs can be obtained by the following formula (Patell 1976):

$$
Z=\text { stand. } C A A R \sqrt{\frac{N(M-4)}{M-2}}
$$

where stand. CAAR is the standardized CAAR of a particular event window $\left[-\mathrm{t}_{1}, \mathrm{t}_{2}\right], \mathrm{N}$ refers to the number of cases, and $\mathrm{M}$ is the number of (trading) days in the estimation period. The most significant event window is chosen for further analysis (for a similar 
procedure, see, e.g., Chaney, Devinney, and Winer 1991; Geyskens, Gielens, and Dekimpe 2002).

\subsubsection{Cross-Case Variation in Stock Price Reactions}

Once we obtained the CAARs and determined the most significant event window, we test our subsequent hypotheses by regressing the per-case CARs on the independent variables. In line with Jain (1982), the $\mathrm{CAR}_{\mathrm{i}}$ were standardized by the standard deviations of the regression residuals (i.e., abnormal returns) of the estimation period (from equation 2). The corresponding formula is:

(8)

$$
\begin{aligned}
\text { stand. CAR }_{i}\left[-t_{1}, t_{2}\right] & =\alpha+\beta_{1} \text { Elimsize }_{i}+\beta_{2} \text { Publicity }_{i}+\beta_{3} \text { Initiator }_{i} \\
& +\beta_{4} \text { FirmSize }_{i}+\beta_{5} \text { FirmSizeOpponent }_{i}+\beta_{6} X_{i}+\varepsilon_{i}
\end{aligned}
$$

where ElimSize $_{i}$ refers to the elimination size of the conflict delisting, Publicity captures the amount of publicity surrounding the delisting, Initiator $r_{i}$ is a dummy variable that captures whether or not the focal firm is the initiator of the conflict

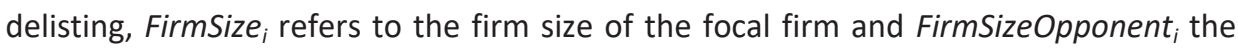
size of the focal firm's opponent, and $X_{i}$ is a vector of control variables including a yearly trend and a set of country dummy variables to control for unobserved heterogeneity between countries. Thirteen firms were engaged in multiple conflict delistings, which may give rise to correlated errors. For example, Dutch retailer Ahold was involved in four conflict delistings between 2000 and 2015 (our sample period). Therefore, we estimate equation 8 with GEEs (generalized estimating equations) (for a similar practice, see Raassens, Wuyts, and Geyskens 2012).

\subsection{EMPIRICAL STUDY}

\subsubsection{Sample}

We composed a sample of conflict delisting announcements by searching the LexisNexis (for events within The Netherlands, United Kingdom, and Germany) and GoPress and PressBanking databases (for Belgian events) over a period of 16 years (2000-2015). This resulted in 142 cases (71 announcements including both a manufacturer and a retailer). We removed 70 cases for which the firm was not listed on any stock exchange. To isolate the influence of the conflict delisting on shareholder value, we checked for confounding events that take place on the announcement date (Hsu and Lawrence 2016). In three cases, other firm information (e.g., firm sales, earnings, product harm crisis) was released. We removed these cases from our sample.

This resulted in a sample of 69 cases that reflect firms that are involved in a particular conflict delisting situation. The sample consists of 36 manufacturing firms 
and 33 retailers, and span 16 industries (e.g., bottled and canned soft drinks, soap and detergents, grocery stores, and general merchandise stores). The majority of the cases in our sample reflect conflict delistings that occurred in the Netherlands (41\%), followed by the United Kingdom (32\%), Germany (25\%), and Belgium (3\%). An overview of all the conflict delistings in our sample can be found in the Appendix of this doctoral dissertation.

\subsubsection{Operationalization and Descriptives}

Shareholder value. We collected stock price information and market indices from the Datastream database. Where possible we always opt for the listing on the local stock market, as the delisting will have the largest impact on the stock market in the focal firm's home country. To exemplify, for the delisting of Coca-Cola in Germany, we used the stock price information and market indices from Coca-Cola Germany. In case the firm was not listed on the local stock exchange (i.e., in the country where the conflict delisting occurred), we took the information from the parent company. For example, for the delisting of Danone in The Netherlands, we rely on French stock market data, as Danone is not listed on the Dutch stock market.

Seriousness of the conflict delisting. We operationalize elimination size as the number of brands that were delisted as a consequence of the conflict, as reported by press sources. ${ }^{11}$ Publicity is measured as the percentage of national newspapers (with a circulation of at least $1 \%$ of the population) ${ }^{12}$ that featured the conflict delisting on the front page, during the event window, relative to the total number of considered national newspapers in the corresponding country. For The Netherlands, UK, and Germany, announcements were searched by means of the LexisNexis database. For Belgium, we searched the GoPress and Pressbanking databases.

\footnotetext{
${ }^{11}$ For sixteen cases, no exact numbers were available. We therefore used the number of brands reported in national newspapers. For example, in the Ahold-Unilever conflict in 2002, various newspapers stated that "several well-known brands were delisted, such as Omo, Croma, Knorr, Unox, Bertolli, and Cif." As six brands were mentioned in the newspaper articles, we impute the missing value on elimination size by six in this case. For the other missing values, the same procedure is followed. To test the robustness of our findings to this particular imputation method, we imputed the missings by the total number of brands of the firm in question, as reported by the company website. Our findings remain robust to this alternative imputation method.

${ }^{12}$ We limited our media search to newspapers with a circulation of at least $1 \%$ of the population. This includes, for the United Kingdom, both the weekly and Sunday editions of (in alphabetical order) Daily Mail, Daily Mirror, Daily Star, The Daily Telegraph, The Express, The Financial Times, The Guardian, The $i$, The Independent, News of the World, The Observer, The People, The Sun, and The Times, for a total of 18 newspapers. For the Netherlands, we included AD/Algemeen Dagblad, Het Financiële Dagblad, Nederlands Dagblad, NRC Handelsblad, Het Parool, De Pers, Reformatorisch Dagblad, De Telegraaf, Trouw, and De Volkskrant. For Flanders, we included Gazet van Antwerpen, Het Laatste Nieuws, Metro, De Morgen, Het Nieuwsblad, De Standaard, and De Tijd. For Wallonia, we included L'Avenir, La Dernière Heure, L'Echo, La Libre, Metro, and Le Soir. For Germany, this included Focus, Handelsblatt, Frankfurter Rundschau, Der Standard, Die Tageszeitung, die Welt, and Die Zeit. Except for Belgium, free newspapers are not part of the electronic databases, and thus, we could not include them in the media search.
} 
Capacity to withstand the negative consequences of conflict delistings. Initiator is a dummy variable which takes the value one when the focal firm initiated the delisting, and is zero otherwise, information which was taken from press sources or the delisting announcement. We hereby focus on the initiator of the focal delisting (i.e., the firm that proactively removes the products from the shelf). We operationalized firm size as the natural logarithm of total assets (in millions) of the focal firm in the year before the delisting announcement, as obtained by the Compustat database. To ensure comparability across different countries, all currencies were converted into Euro's using the exchange rate on the day of the annual report. The same procedure was repeated to obtain the firm size of the opponent. For the opponents for which no data were available in the Compustat database, we searched for information in annual reports as reported by other financial databases (i.e., Orbis, Bundesanzeiger, Kamer van Koophandel, Bureau van Dijk), on the company websites of the opponent firms, or via a general Internet search (e.g., company.info). ${ }^{13}$ Table 3.2 presents a summary description of all operationalizations of the independent variables, and Table 3.3 provides the descriptive statistics and correlations.

Table 3.2: Explanatory Variables and Data Sources

\begin{tabular}{|c|c|c|}
\hline Variable & Operationalization & Data source \\
\hline $\begin{array}{l}\text { Elimination } \\
\text { size }\end{array}$ & The number of brands that were delisted. & $\begin{array}{l}\text { LexisNexis, GoPress, } \\
\text { Pressbanking }\end{array}$ \\
\hline Publicity & $\begin{array}{l}\text { Percentage of national newspapers (with circulation of at least } \\
1 \% \text { of the population) in which the conflict delisting was featured } \\
\text { on the front page in the event window, relative to the total } \\
\text { number of considered national newspapers in the corresponding } \\
\text { country. }\end{array}$ & $\begin{array}{l}\text { LexisNexis, GoPress, } \\
\text { d Pressbanking }\end{array}$ \\
\hline Initiator & $\begin{array}{l}\text { Dummy variable which takes the value one when the focal firm } \\
\text { initiated the conflict delisting, and is zero otherwise. }\end{array}$ & $\begin{array}{l}\text { LexisNexis, GoPress, } \\
\text { Pressbanking }\end{array}$ \\
\hline Firm size & $\begin{array}{l}\text { Natural logarithm of total assets (in millions) of the focal firm in } \\
\text { the year before the conflict delisting announcement. }\end{array}$ & Compustat \\
\hline $\begin{array}{l}\text { Firm size } \\
\text { opponent }\end{array}$ & $\begin{array}{l}\text { Natural logarithm of total assets (in millions) of the opponent of } \\
\text { the company in the year before the delisting announcement. }\end{array}$ & $\begin{array}{l}\text { Compustat, Orbis, } \\
\text { Bundesanzeiger, } \\
\text { Kamer van Koophandel, } \\
\text { Bureau van Dijk, company } \\
\text { websites, company.info }\end{array}$ \\
\hline
\end{tabular}

${ }^{\text {(a) }}$ For three opponents, firm size data was not available in the year before the conflict delisting. These missings were replaced by the firm size of the earliest available firm size data (i.e., for Norma data from 2005 was used instead of 2003, for Storck 2004 instead of 2003, and for Marktkauf we used data from 2003 instead of 2000).

\footnotetext{
${ }^{13}$ For three opponents, firm size data was not available in the year before the conflict delisting. The missings were replaced by the firm size of the earliest available firm size data (i.e., for Norma we used data from 2005 instead of 2003, for Storck data from 2004 rather than 2003 is used, and for Marktkauf we used data from 2003 instead of 2000). We did a robustness check to test the robustness of our findings to this imputation, and excluded the three cases from analysis. Our results remain robust. For opponent Bonne Maman, information on assets is missing. This case is therefore excluded from our sample.
} 
Table 3.3: Descriptive Statistics and Correlation Matrix

\begin{tabular}{|c|c|c|c|c|c|c|c|c|}
\hline Variable name & $\mathrm{M}$ & SD & $\begin{array}{c}\text { Stand. } \\
\operatorname{CAR}_{\mathrm{i}}[0,1]\end{array}$ & $\begin{array}{c}\text { Elimination } \\
\text { size }\end{array}$ & Publicity & Initiator & Firm size & $\begin{array}{l}\text { Firm size } \\
\text { opponent }\end{array}$ \\
\hline Stand. $\mathrm{CAR}_{\mathrm{i}}[0,1]$ & -.36 & 1.94 & 1.00 & & & & & \\
\hline Elimination size & 2.88 & 4.58 & -.41 & 1.00 & & & & \\
\hline Publicity & .03 & .07 & -.20 & .16 & 1.00 & & & \\
\hline Initiator & .49 & .50 & .13 & .04 & .06 & 1.00 & & \\
\hline Firm size & 9.44 & 1.72 & .15 & .08 & -.10 & -.20 & 1.00 & \\
\hline Firm size opponent & 8.81 & 2.07 & .01 & .14 & .05 & .04 & .21 & 1.00 \\
\hline
\end{tabular}

\subsection{RESULTS}

Table 3.4 presents information on the CAARs for the 69 conflict delisting cases for different event windows. On the announcement day, the AAR is $-.44 \%$ (Patell $z=-$ 1.586, $p<.10)$, indicating an overall negative reaction of the stock market to the delisting announcement on the event day. Of all windows surrounding the event day, window $[0,1]$ shows the most significant CAAR: CAAR[0,1] $=-.66 \%$ (Patell $z=-2.984, p<$ .01). The negative sign reflects that, in support of $\mathrm{H} 1$, the overall investor response is significantly negative, indicating that conflict delistings are expected to cause negative future cash flows. This finding is consistent with extant research which shows that a conflict delisting leads to decreased brand and category shares (Van der Maelen, Breugelmans, and Cleeren 2017).

Although conflict delistings are, on average, evaluated negatively by investors, there is substantial variation in the stock market consequences of conflict delistings across firms. While $57 \%$ of the conflict delistings show a negative abnormal return over the event window (CAAR $=-2.31 \%$ ), investors positively evaluated $43 \%$ of the conflict delistings (CAAR $=1.48 \%$ ). To understand this cross-sectional variation, we estimated equation 8 with the individual firms' standardized CARs as dependent variable. Table 3.5 presents the results. In Table 3.3, we report the correlations between the different independent variables. The maximum absolute correlation is -.41 , well below .80 (Judge et al. 1998). In addition, the maximum variance inflation factor is 2.64, indicating that multicollinearity is not an issue (Hair et al. 2010).

Table 3.4: CAARs for Different Event Windows

\begin{tabular}{llllc}
\hline Event Window & CAAR & \% Positive & Patell z-Statistic & $p$-value \\
\hline$[-1,2]$ & -.0043 & 47.8 & -2.266 & .01 \\
{$[-1,1]$} & -.0057 & 44.9 & -2.577 & $<.01$ \\
{$[-1,0]$} & -.0042 & 50.7 & -1.178 & .12 \\
{$[0,2]$} & -.0049 & 43.5 & -2.673 & $<.01$ \\
{$[0,1]$} & -.0066 & 43.5 & -2.984 & $<.01$ \\
{$[0,0]$} & -.0044 & 46.4 & -1.586 & .06 \\
\hline
\end{tabular}


Table 3.5: Empirical Results

\begin{tabular}{|c|c|c|c|}
\hline & Hypothesized Sign & Coefficients & Standard Error \\
\hline Intercept & & $-4.190 * * *$ & 1.868 \\
\hline \multicolumn{4}{|c|}{ Seriousness of Conflict Delisting } \\
\hline Elimination size & - & $-.201 * * *$ & .044 \\
\hline Publicity & - & $-7.436 * *$ & 2.928 \\
\hline \multicolumn{4}{|c|}{ Capacity to Withstand Negative Consequences } \\
\hline \multicolumn{4}{|l|}{ Conflict Delisting } \\
\hline Initiator & + & $.703^{*}$ & .379 \\
\hline Firm size & + & $.296 * *$ & .126 \\
\hline Firm size opponent & - & .097 & .110 \\
\hline \multicolumn{4}{|l|}{ Control Variables } \\
\hline Netherlands & & $1.011^{*}$ & .615 \\
\hline Germany & & .351 & .559 \\
\hline Belgium & & $4.364 * * *$ & 1.268 \\
\hline Year & & .005 & .053 \\
\hline \multicolumn{4}{|l|}{ Other Statistics } \\
\hline Number of observations & & $68^{(\mathrm{a})}$ & \\
\hline Wald Chi-square & & $37.81^{* * *}$ & \\
\hline R-square & & .358 & \\
\hline
\end{tabular}

(a) For one case we do not have information on the opponent's firm size, therefore we cannot take this case into account for the analysis (see also footnote 13).

* Significant two-tailed result at $10 \%$ significance level

** Significant two-tailed result at $5 \%$ significance level

*** Significant two-tailed result at $1 \%$ significance level

\subsubsection{Seriousness of the Conflict Delisting}

Hypotheses 2 and 3 relate to the seriousness of the conflict delisting. We find strong support for the anticipated negative effect of the conflict severity on the relationship between a conflict delisting and firm value. As hypothesized ( $\mathrm{H} 2)$, we find that investor responses to a conflict delisting become more negative when the elimination size increases $(\beta=-.201, p<.01)$. When a delisting involves multiple brands, the negative effects of a conflict delisting are strengthened. More publicity surrounding a conflict delisting also negatively affects investor responses in a conflict delisting $(\beta=-7.436, p<$ $.05)$, which confirms hypothesis 3 . More publicity makes more consumers and business partners aware of the conflict, which increases the potential negative consequences, and hence the negative investor responses.

\subsubsection{Capacity to Withstand the Negative Consequences of Conflict Delistings}

We find that firms with a higher capacity to withstand the negative consequences of conflict delistings are able to attenuate the negative effects. Investor responses 
toward a conflict delisting less negative when the focal firm initiates the delisting $(\beta=$ .703, $p<.10$ ), thereby providing support for $\mathrm{H} 4$. Initiating a conflict delisting might signal a strong and deliberate strategy towards investors, demonstrating that the focal firm is powerful and optimistic regarding the financial outcomes of the conflict delisting. As expected (H5), a firm is able to withstand the negative consequences of a conflict delisting if it is large in size $(\beta=.296, p<.05)$. Large firms have more tangible resources which they can use to 'beat' their opponent. Moreover, large firms might be more likely to win the negotiation process. Surprisingly, the size of the opponent does not significantly impact investor responses to conflict delistings ( $H 6, \beta=.097, p>.10$ ).

\subsection{ROBUSTNESS CHECKS}

We test the robustness of our findings in three ways: (1) by using different methods for error clustering, (2) using different operationalizations of our independent variables, and (3) adding additional control variables to rule out alternative explanations.

\subsubsection{Different Methods of Error Clustering}

In our estimation model, we controlled for clustered errors for firms that were involved in multiple conflict delistings, by using a GEE model specification. However, for some events, both the manufacturer and retailer are listed on the stock market, which are considered as separate cases in our dataset. As this may also give rise to correlated errors, we re-estimate equation 8 with GEEs correcting for the paired manufacturer and retailer within one conflict situation (instead of correcting for multiple firms in the sample). Our findings remain robust to this alternative specification.

\subsubsection{Different Operationalizations of Independent Variables}

As depicted in the summary descriptives (Table 3.3), there is limited variation in our publicity measure. On average, the conflict delisting is featured on the front page during the event window in only $3 \%$ of the national newspapers. To assess the robustness of our findings, we test for an alternative specification of the publicity measure. In particular, we measure the number of times the focal firm was mentioned in articles about the conflict delisting, relative to the total number of newspapers in a country. Our findings are robust to this alternative specification.

There are multiple ways to operationalize the size of the focal firm and its opponent. While we measure firm size by total assets, one can also use a composite measure of total assets, sales, and employees in the year before the announcement (e.g., Geyskens, Gielens, and Dekimpe 2002; Raasens, Wuyts, and Geyskens 2012). The 
components are standardized, before averaging them into a single variable, which is then log-transformed. Because the logarithm of a negative value is undefined, we added a small positive value (1) to all data points before taking the logarithm (see Geyskens, Gielens, and Dekimpe 2002 for a similar practice). For consistency, we operationalize the opponent's firm size in the same way. In addition, we re-estimate our model by including the natural logarithm of sales and the number of employees as individual measures of firm size. For all alternative specifications, our results are robust, with the exception of initiator, which becomes marginally insignificant.

In addition, we empirically tested the size of the focal firm relative to its opponent (i.e., the natural logarithm of total assets of the focal firm divided by the natural logarithm of total assets of its opponent). When a focal firm is larger in size than its opponent, one can argue that the capacity to withstand the negative consequences of a conflict delisting is larger compared to when both firms are of equal size. However, we do not find any empirical evidence supporting this assertion.

\subsubsection{Adding Control Variables to Rule out Alternative Explanations}

We include profitability as a control variable to control for a firm's past performance (e.g., Raassens, Wuyts, and Geyskens 2014). On the one hand, if a firm has a strong track record of high profitability, one can argue that it is successful in its operations, which can positively be reflected in the conflict delisting negotiations. Profitability is in this case a reflection of good negotiations skills, thus the firm is expected to "win" the current negotiations at hand. On the other hand, if a firm has poor profitability, investors might be happy that it is putting their foot down in negotiations, which might be a signal that it is changing tracks and taking active steps to increase profitability. In line with previous research, profitability is measured as the ratio of net income to sales in the year before the conflict delisting announcement (e.g., Luo 2007). ${ }^{14}$ Our results show that neither the profitability for the focal firm, nor the opponent's profitability significantly affects investor responses, indicating that the two opposing forces might cancel each other out.

Besides profitability, we control for the financial leverage of a firm (e.g., Raassens, Wuyts, and Geyskens 2012). Leverage is operationalized as the ratio of long-term debt (in millions of Euros) to total assets (in millions of Euros) of the firm in the year before the delisting announcement. ${ }^{15} \mathrm{~A}$ higher debt-to-asset ratio means that a firm has less short-term access to its financial assets; hence we would expect a negative effect as these firms are less capable to withstand the negative consequences of a conflict delisting. However, we do not find support for this claim, as neither the coefficient for

\footnotetext{
14 For Stollwerck and Storck, net income was not available for the year before the announcement (respectively 1999 and 2003), we therefore used the earliest available data (i.e., 2002 and 2005, respectively).

${ }^{15}$ For three opponents, the annual statement did not distinguish between long-term and short-term debt (i.e., Bitburger (Gerolsteiner), Lieken, and Kaufland). In these cases, the total-debt was used.
} 
the financial leverage of the focal firm nor for the opponent's financial leverage are statistically significant. Our other findings remain robust.

Our sample consists of both manufacturers (52\%) and retailers (48\%). Although we do not have any a priori expectations, we test whether there is a difference in investor response between the two parties. We add a dummy variable to our model, indicating whether the focal firm is a manufacturer $(=1)$ or a retailer $(=0)$. We do not find a significant difference in the performance implications of conflict delistings between manufacturers and retailers.

\subsection{DISCUSSION}

Research on conflict delistings is scarce, leaving both academics and practitioners in the dark about its possible consequences. Recently, extant literature has started to identify the performance implications of conflict delistings in terms of sales and market share (Van der Maelen, Breugelmans, and Cleeren 2017). However, the true impact of conflict delistings on firm value go well beyond this direct sales effect, as it may also place future collaborations and negotiations between the conflicting parties and other channel partners at risk. Using the event study methodology, we investigate the overall impact of conflict delistings on firm value, and find support for an overall negative effect of conflict delistings on shareholder value.

Anecdotal evidence shows that there is a lot of cross-sectional variation in the stock market response to conflict delisting announcements. Our results corroborate this anecdotal evidence. Indeed, while $57 \%$ of the conflict delistings in our sample result in a negative shareholder reaction, investors positively evaluated $43 \%$ of the conflict delistings. To explain this cross-sectional variation in investor responses to conflict delistings, we build a contingency framework in which we investigate in which situations conflict delistings are more or less harmful.

Extending previous research by Gielens et al. (2008), we show that the driving factors behind the cross-sectional variation in the stock market response are 1) the seriousness of the conflict delisting and (2) the capacity to withstand the negative consequences of a conflict delisting. A first and important insight that can be derived from our analysis is that the seriousness of the delisting is inversely related to shareholder value in conflict delistings. This is in line with the findings of Gielens et al. (2008), who show that shareholder value substantially decreases when the seriousness of the threat increases. To shed more light on the wide array of conflict delistings, we use both the number of delisted brands and the amount of publicity surrounding the conflict delisting announcement as measures of the seriousness of the conflict delisting, and find support for both components. A more severe conflict delisting, i.e., one in which multiple brands are delisted, bring about more negative investor responses. For every brand that is unavailable, firms risk losing consumers due to 
switching behavior to other brands or stores (Campo, Gijsbrechts, and Nisol 2000). In addition, a large elimination size might indicate a significant disruption in the manufacturer-retailer relationship, which might lead to unfavorable long-term consequences (Skinner, Gassenheimer, and Kelley 1992). Furthermore, in line with extant research on publicity (e.g., Chevalier and Mayzlin 2006), publicity negatively impacts the effect of a conflict delisting on shareholder value. Arguably, publicity heightens the awareness of a negative event among both consumers and the firm's channel partners, resulting in negative investor responses (cf. Hsu and Lawrence 2016; Van Heerde, Gijsbrechts, and Pauwels 2015; Verhoef and Sloot 2006).

Second, the firm's capacity to withstand the negative consequences of a conflict delisting is also an important factor in explaining the cross-sectional variation in the stock market response. In line with our expectations, the performance implications of a conflict delisting are less negative if the focal firm is the initiator of the delisting. Indeed, a firm may start a conflict delisting only when they expect to win the negotiation process and initiating a conflict delisting may, thus, be regarded as a signal towards investors that the firm is a dominant player in the market. Simultaneously, the focal firm warns other channel members about its dominant position. We further show that small firms are much more negatively affected by conflict delistings than large firms. Relative to its large counterparts, small firms typically have less access to tangible resources, making them more dependent on the revenue streams from all products (Thirumalai and Sinha 2011). Large firms, on the contrary, have a larger financial buffer, making them less vulnerable to disruptions in their marketing channels. Moreover, large firms can utilize access to tangible resources to launch marketing campaigns to mitigate negative effects of conflict delistings and to educate or hire trained negotiators. Surprisingly, the size of the opponent does not impact investor responses to conflict delistings. Apparently, investors take an internal perspective, and do not take into account (external) partner information.

\subsubsection{Managerial Implications}

This study identifies factors that can either decrease or enhance firm value in conflict delistings. While the seriousness of a conflict delisting can be damaging, firms with a high capacity to withstand the negative consequences of a conflict delisting may be able to protect themselves against the possible negative effects. To find out exactly which of these factors will prevail in each different conflict situation, we conducted a what-if analysis, delineating the performance outcomes in different conflict situations. Table 3.6 presents the results. 
Table 3.6: Predicted CARs as a Function of the Seriousness of the Delisting and Capacity to Withstand Negative Consequences ${ }^{(a)}$

\begin{tabular}{|c|c|c|c|c|c|}
\hline \multirow[t]{2}{*}{ Elimination size } & \multirow[t]{2}{*}{ Publicity } & \multicolumn{2}{|c|}{ Non-initiating party } & \multicolumn{2}{|c|}{ Initiating party } \\
\hline & & Small firm & Large firm & Small firm & Large firm \\
\hline \multirow[t]{2}{*}{ Low } & Low & -.24 & .78 & .47 & 1.49 \\
\hline & High & -1.0 & .02 & -.29 & .72 \\
\hline \multirow[t]{2}{*}{ High } & Low & -1.54 & -.52 & -.83 & .19 \\
\hline & High & -2.30 & -1.28 & -1.59 & -.58 \\
\hline
\end{tabular}

(a) To calculate the predicted CARs, the indicator variable to measure initiator is set to zero or one, while the continuous variables to measure the seriousness of the delisting and the capacity to withstand the negative consequences of the delisting (i.e., elimination size, publicity, and firm size) are set to one standard deviation above or below their mean (except for low elimination size and low publicity, where we use the minimum instead of one standard deviation below the mean to stay within the range of the data). The other variables are held fixed at their baseline level (i.e., zero for indicator variables and the mean for continuous variables).

For the managerial implications, particular interest should be paid to the initiator of the conflict delisting and the elimination size, as these are the most important actionable parameters that business managers can actively take into consideration when faced with a conflict situation. More specifically, manufacturers and retailers can deliberately choose to initiate a conflict delisting. Subsequently, the initiating firm can determine whether to delist a small or large number of brands, and is, therefore, able to obtain more than an estimated guess about the impact of a conflict delisting. For example, from our what-if-analysis in Table 3.6, we derive the following for Dutch firms in the year 2000 (as our baseline case). First, for large firms, it is always better to be the initiating party of the conflict delisting, except when the conflict is likely to be very serious (i.e., when the conflict delisting involves a large number of delisted brands and receives lots of publicity). Second, for small firms it can also be interesting to initiate a delisting, but only if the seriousness of the conflict delisting is low. Third, if a large firm gets caught up in a conflict delisting by another party and the number of brands delisted is rather small, they should not worry about the consequences as it will be profitable. In any other case, for a Dutch firm under these conditions conflict delistings will only lead to damages in firm value.

While managers cannot directly influence the publicity surrounding the delistings, the simulations provide them with a precise range. To run the simulations (i.e., calculate the predicted (AR's) for other countries and years, we would add the corresponding coefficients from Table 3.5 to the estimated values in Table 3.6. For example, for the UK, we deduct a value of 1.01 to every cell in Table 3.6. Thus, companies can use our findings to estimate the consequences of initiating a conflict delisting, and can subsequently use it to determine the optimal elimination size. In addition, the simulations also indicate the predicted performance consequences for firms that are the recipient of a conflict delisting. Subsequently, if the predicted performance consequences are very severe, they can act upon this in two ways. On the 
one hand, they can choose to agree upon the opponent's terms of negotiations, thereby limiting the severity of the conflict delisting. On the other hand, however, they can choose to actively fight the opponent, by employing various marketing actions such as advertising support or price reductions.

\subsubsection{Limitations and Suggestions for Future Research}

Our study has several limitations that offer avenues for further research. First, while our study focuses on the overall impact of conflict delistings, which allows us to determine the net effect of a conflict delisting for different firms and conflict delisting situations, it is worthwhile that future research disentangles this effect. For example, future research could build on our finding that shareholder value increases when the seriousness of the conflict delisting is low and a firm has a high capacity to withstand the negative consequences of a delisting by empirically investigating the drivers of this effect (e.g., increase in profit margin, stronger position in the market). As another example, future research could look into the damages a conflict delisting may cause to the manufacturer-retailer relationship, for example, by investigating how a conflict delisting will manifest itself in the future relationship (e.g., less support for new product introductions, allocation of less shelf space).

Second, elimination size is measured in absolute terms (i.e., the number of brands delisted). A relative measure indicating the percentage of the focal firm's assortment that is affected could further capture the seriousness of the delisting. Furthermore, the extent to which conflicts may harm or benefit the parties involved might also be influenced by the extent to which both parties depend on one another. A high dependence on the other party could therefore represent an additional dimension for the seriousness of the delisting, i.e., if the dependency of the focal firm on the opponent is high, the conflict delisting situation is more serious, which will negatively affect shareholder value. This might be captured by 1 ) the share of sales or profits derived through the other party (i.e., the contribution-to-sales and contribution-toprofits measure), or 2) the availability of alternatives in case the focal relationship is lost (c.f., Geyskens, Gielens, and Dekimpe 2002). These measures are not included in our model due to the unavailability of the data; however, they provide fruitful avenues for future research.

Third, it would be worthwhile to investigate which managerial actions manufacturers and retailers have at their disposal to counter the negative effects of a conflict delisting. From trade press, we know that both manufacturers and retailers make use of their arsenal of marketing actions in an attempt to keep consumers from switching brands or stores. Examples include Unilever engaging in a widely spread advertisement campaign (Metro 2009) and Coca-Cola offering price promotions on Fanta during a conflict delisting (Distrifood 2005b). Marketing actions might impact firm value through consumer reactions (e.g., price promotions could lead to more 
future purchases), but also provide a signal to investors. This signal may not necessarily be positive as demonstrated by Chen, Ganesan, and Liu (2009), who find that proactive strategies might have a negative effect on firm value as they signal a lack of manager's confidence in a good financial outcome.

Fourth, our sample almost completely consists of cases where price negotiations went sour. Because the effect of a conflict delisting on firm value might depend on the nature of the conflict (e.g., price related versus non-price related conflicts), we encourage scholars to distinguish between the different types of conflict delistings when examining its performance implications.

Finally, although this study concentrates on the performance implications of conflict delistings, not all power battles result in a conflict delisting. It would, therefore, be interesting to compare the differential effects of power battles that did not lead to a conflict delisting and power battles that escalated into a conflict delisting. While our finding regarding elimination size hints at less severe consequences for power battles that did not result in conflict delistings, future research could provide more insights into the underlying causes, i.e., is the power or the unavailability aspect driving our effect?

In conclusion, by analyzing the impact of conflict delistings on firm value and identifying the factors that distinguish more versus less harmful conflict delistings, we provide a much needed first picture on the overall impact of a conflict delisting in different circumstances. 

Chapter

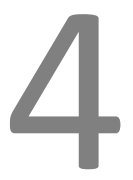

Conclusion 

Conflict delistings are omnipresent in today's marketplace. The frequent reliance of companies on conflict delistings signifies that this will not always be harmful, but rather is likely to be advantageous in some situations. This dissertation focuses on the performance implications of conflict delistings, and investigates conditions under which conflict delistings are less or more harmful. This chapter discusses the main findings, managerial implications, and directions for further research.

\subsection{SUMMARY AND CONCLUSIONS}

What are the performance implications of conflict delistings? This dissertation contains two chapters dedicated to answering this question. In the following subsections, I discuss the findings per chapter, and conclude with a comparison between the two studies.

\subsubsection{Chapter 2: The Effectiveness of Managerial Actions during Conflict Delistings}

Due to the rise of powerful retailers, (price) negotiations between manufacturers and retailers often go sour and result in conflict delistings, where the manufacturers' brands get removed from the retailers' assortment. Such conflict delistings can cause major revenue and sales losses for both manufacturers and retailers. The extant literature lacks knowledge on the effectiveness of marketing actions used by manufacturers and retailers to alleviate these severe damages. To fill this gap, I use a contingency framework to assess advertising and price effectiveness for both manufacturers and retailers in different conflict situations, i.e., the degree of publicity and the role of the initiator of the conflict.

Using household purchase data for a wide variety of conflict delistings - spanning different years, countries, categories, manufacturers, and retailers - the findings reveal that both advertising support and price reductions are less effective for the manufacturer when they are faced with a conflict situation that receives a lot of publicity. The results further show that price reductions are an effective marketing tool for the initiator of the conflict, but the initiator should refrain from increasing its advertising spending. For the other party, the effects are reversed: advertising is more effective while price reductions are not advisable.

\subsubsection{Chapter 3: The Market Valuation of Conflict Delistings}

Although it is generally accepted that it is in both the manufacturers' and retailers' best interest to find ways to cooperate, negotiations between the two parties often go sour. One strategy that manufacturers and retailers often use in an attempt to stand their ground in the negotiation process is a conflict delisting, where products are removed from the shelves until the conflict is resolved. Despite the frequent 
occurrence and inherent managerial importance, both academics and practitioners lack information on the performance consequences of conflict delistings for the firm. Therefore, I use the event study methodology to investigate changes in firm value elicited by conflict delistings.

Using an international sample of 69 conflict delistings, the findings reveal that, overall, conflict delistings severely damage firm value. However, substantial cross-case variability is present. This variability is explained by means of a contingency framework, in which the large variability between cases is driven by the seriousness of the delisting (i.e., the number of delisted brands and the degree of publicity) and the capacity to withstand negative consequences of the delisting (i.e., initiator of the delisting, firm size focal firm and opponent). The findings demonstrate that, when the elimination size and the amount of publicity surrounding the delisting is large, conflict delistings more negatively impact firm value. Companies can safeguard themselves against the negative consequences by initiating the delisting or by means of a large firm size.

\subsubsection{Comparison of the Two Studies}

Both Chapter 2 and 3 investigate the performance implications of conflict delistings, albeit from a different perspective. It is therefore interesting to compare the results of the two chapters.

Performance Implications of Conflict Delistings. Both chapters lead to the conclusion that, on average, conflict delistings severely harm firm performance. The results from Chapter 2 show that, on average, conflict delistings severely harm both brand and category sales. In Chapter 3, we see that, on average, shareholder value decreases due to delisting announcements. These results point at a no-win situation for both conflicting parties. However, the results also show that the situation is more nuanced, as the performance consequences are contingent upon different factors.

When Are Conflict Delistings More or Less Harmful? In both studies, I investigate various characteristics that may affect the relationship between conflict delistings and firm performance. In both studies, I examine the role of the initiator, the amount of publicity surrounding the delisting, and the elimination size (i.e., number of delisted brands). Interestingly, both consumers (Chapter 2) and investors (Chapter 3) punish the initiating party of the conflict delisting less severely. One exception is that retailer sales are not affected when the retailer is the initiating party compared to when they are not the initiating party. I presume that consumers have empathy for the manufacturer when they initiate a conflict delisting, while for investors initiating a delisting is a sign of strength and dominance.

The results for the amount of publicity surrounding the conflict are mixed. In Chapter 2 findings suggest that the changes in brand and category sales because of the conflict delistings are not dependent on the amount of publicity. In contrast, investors 
do respond to the amount of publicity, in a negative manner (Chapter 3). Apparently, consumers are not driven by the amount of publicity, but investors are. This finding is in line with extant literature (e.g., Van Heerde, Gijsbrechts, and Pauwels 2015). While the effect of publicity is ambiguous for consumers, it is negative for investors. For consumers, two opposing effects may cancel each other out. On the one hand, negative publicity surrounding a conflict delisting emphasizes the conflict and the resulting unavailability of the products (e.g., Verhoef and Sloot 2006), thereby leading to decreased brand equity of the involved parties. On the other hand, negative publicity can positively increase awareness for the brands and retailer (Berger, Sorenson, and Rasmussen 2010). On the long run, the negative valence may wear out, while the positive consumer attention effect persists (Berger, Sorenson, and Rasmussen 2010; Cleeren, Van Heerde, and Dekimpe 2013). Investors go beyond the consumer effect and also take the effect of publicity on other stakeholders into account, such as other channel members. Generally, the increased attention surrounding a negative event makes investors uncomfortable, since it may reduce future cash flows (Hsu and Lawrence 2016; Van Heerde, Gijsbrechts, and Pauwels 2015).

While Chapter 2 concludes that a higher elimination size is beneficial for brand sales, and does not affect category sales, Chapter 3 concludes that a conflict delisting involving a large number of brands is detrimental for firm value. Consumers are more likely to switch to a different store if the delisting involves a large elimination size, which increases brand sales. Investors, however, may assume that a higher elimination size will lead to more severe sales consequences of the conflict delisting. In addition, a large elimination size may disrupt and therefore impact the future manufacturerretailer relationship more than a delisting in which only a small number of brands are delisted, and therefore harm future negotiations between the conflicting parties.

\subsection{PRACTICAL IMPLICATIONS}

The findings of the two studies provide managers with insights into how to react to conflict delistings.

\subsubsection{Chapter 2: The Effectiveness of Managerial Actions during Conflict Delistings}

Chapter 2 provides managers with insights into 1) when different conflict delistings are more or less harmful, and 2) which marketing actions are useful in which conflict situations to safeguard themselves against harmful sales consequences. First, the results show that, for the manufacturer, initiating a conflict delisting is less harmful than being at the receiving end of a delisting. Managers need not worry about the amount of publicity, as it does not impact either brand or category sales. Second, and most importantly, Chapter 2 provides marketers with exact insights into which 
marketing actions (i.e., advertising support or price reductions) to use in which conflict situations (i.e., initiator and publicity) in order to alleviate the damages caused by conflict delistings. More specifically, a marketing dashboard is composed outlining the optimal actions in each specific conflict situation. To exemplify, manufacturers need to increase their advertising support and stay away from price reductions for conflict delistings initiated by the retailer and not surrounded by publicity. In contrast, for the retailer the opposite holds: if a retailer initiates a delisting, which is not surrounded by publicity, they benefit from offering price reductions and refraining from increasing advertising support.

\subsubsection{Chapter 3: The Market Valuation of Conflict Delistings}

Chapter 3 provides insights into factors that impact changes in firm value due to a conflict delisting. This study therefore provides insights into when conflicts are more or less harmful. A what-if analysis is conducted and the consequences of every scenario are estimated. Especially the initiator of the delisting and elimination size are of particular interests to retailers and manufacturers, as managers can influence them directly.

The results of the simulation reveal that for the baseline scenario, Dutch firms in the year 2000, it is profitable for large firms to be the initiating party, except when it concerns a very severe delisting accompanied by a high amount of publicity and in which a large amount of products are removed from the shelves. Parties are therefore advised not to eliminate a large amount of products in these circumstances, as it will always harm firm performance. In addition, for small companies, initiating a delisting with a small elimination size is only advisable if they foresee little publicity around the delisting. Finally, if an opposing firm initiates a conflict delisting for a large company, the delisting might be profitable as long as the conflict delisting is small in elimination size and receives little to no publicity. Overall, it is in the companies' best interest to refrain from eliminating a large range of products or to tip the public press about the delisting.

\subsection{FUTURE RESEARCH}

This dissertation provides valuable insights with regard to the performance consequences of conflict delistings. In this section I provide several suggestions for future research.

\subsubsection{Additional Stakeholders}

In addition to consumer and investor responses, conflict delistings may change the relational dynamics between the involved firms and other parties. 
Non-involved retailers. Manufacturers' brands are typically distributed at multiple retailers (Coughlan et al. 2006), as higher levels of distribution lead to higher market share (Reibstein and Farris 1995), and in turn may lead to higher profit. Consequently, manufacturers frequently negotiate their terms of agreement with multiple retailers. As mentioned in Chapter 3, conflict delistings could change the relational dynamics between the involved manufacturer and involved retailer, as a party's bargaining position is weaker the more it loses in case of failure (Draganska, Klapper, and VillasBoas 2010). Subsequently, when a manufacturer is involved in a conflict delisting, it may alter the position of the manufacturer in the grocery market, and hence may spillover and impact negotiations with non-involved retailers. This is especially the case when the breakdown of the negotiations are discussed in the media. Future research could complement this research by investigating the impact on future negotiations between the manufacturer and non-involved retailers.

Non-involved manufacturers. In a similar vein, retailers typically negotiate with many manufacturers, and conflict delistings might strengthen or weaken their negotiation position with manufacturers that are not directly involved in the conflict delisting. Moreover, suppliers have reported for years that big-box retailers are pressuring them into accepting complying with conditions that undermine channel profits (Huang et al. 2012).

Engaging in a conflict delisting could support this perception. Whether this is beneficial or detrimental for future negotiations is a question for further research.

Competitors. Competitors provide an avenue for further research, in two distinct ways. First, given that, on average, conflict delistings are a no-win situation for both involved parties, it is likely that the competitor is the real winner of a conflict. To exemplify, in the Unilever - Delhaize conflict, competitor Colruyt was crowned the winner as consumers massively switched their purchases to Colruyt (Brandhome 2009). Future research should investigate whether this finding can be generalized. Second, competitor reactions may impact the consumer and investor responses to conflict delistings. In Chapter 2, we measure the relative advertising and price responses to the top 5 competitors, thereby providing first insights into these dynamics. Future research could complement this by investigating the absolute impact of competitor responses, and more specifically, provide insights into which competitor has the most impact.

\subsubsection{Impact on the Long-Term Manufacturer-Retailer Relationship}

Future research could zoom in deeper on how the long-term relationship between the involved manufacturer and retailer is affected by conflict delistings. In Chapter 3, I indirectly take this into account into the aggregated measure of firm value, but future research might take a more disentangled perspective and might provide more insights into how exactly this relationship is affected. As discussed in Chapter 3, a change in the 
manufacturer-retailer relationship can be depicted in the (marketing-mix) outcomes of future negotiations, for example, by less new product introductions for the involved manufacturer (product), less trade-promotions (price), less advertising support (promotion), or shelf space (place). In a similar vein, manufacturers can opt for increasing distribution at other channel partners, or opt for direct distribution to the end-consumer, thereby bypassing the retailer (encroachment).

\subsubsection{In-store Marketing Actions}

In Chapter 2, I investigate the role of marketing actions in consumer responses to conflict delistings. However, retail stores also have the option to strategically alter the in-store communication and shelf space allocation. These in-store marketing actions provide avenues for future research.

In-store communication. Due to data unavailability, it was not possible to observe in-store marketing actions. However, retailers have the option to strategically provide in-store messages to consumers, in which they communicate the conflict delisting towards consumers. For example, US retailer Costco placed the following message when they delisted Coca-Cola due to a conflict: "At the present we are not carrying Coke, Diet Coke, Sprite or any Coke products. This is because in our view Coca Cola has not provided us with competitive pricing, so we cannot provide the value our members deserve. We apologize for any inconvenience." Although we already have some information about the effectiveness of in-store displays in a regular online out-of-stock context (Breugelmans, Campo, and Gijsbrechts 2006), in-store shelf information might work differently in a conflict setting, and could be an effective marketing action for retailers to alleviate damages. Future research could investigate whether these messages are effective, and if so, which elements the message needs to contain (e.g., apology, explanation, taking blame).

Shelf space. In addition, retailers control the in-store shelf allocation during a delisting. Retailers can make use of this opportunity to allocate more shelf space to either their private label brand or other national brands. Future research could look into these in-store marketing actions that retailers have at their disposal, for example by means of laboratory or natural field experiments. 
References 
Aaker, David A. (1991), Managing Brand Equity: Capitalizing on the Value of a Brand Name, Free Press, New York.

Aalto-Setälä, Ville (2002), "The Effect of Concentration and Market Power on Food Prices Evidence from Finland," Journal of Retailing, 78 (3), 207-216.

Ahluwalia, Rohini, Robert E. Burnkrant, and H. Rao Unnava (2000), "Consumer Response to Negative Publicity: The Moderating Role of Commitment," Journal of Marketing Research, 37 (2), 203-214.

Ailawadi, Kusum L. (2001), "The Retail-Power Performance Conundrum: What Have We Learned?" Journal of Retailing, 77, 299-318.

—, Norm Borin, and Paul W. Farris (1995), "Market Power and Performance: A Cross-Industry Analysis of Manufacturers and Retailers," Journal of Retailing, 71 (3), 211-248.

_ - Eric T. Bradlow, Michaela Draganska, Vincent Nijs, Robert P. Rooderkerk, K. Sudhir, Kenneth C. Wilbur, and Jie Zhang (2010), "Empirical Models of Manufacturer-Retailer Interaction: A Review and Agenda for Future Research," Marketing Letters, 21 (3), 273-285.

Anderson, Eric T., Gavan J. Fitzsimons, and Duncan Simester (2006), "Measuring and Mitigating the Costs of Stockouts," Management Science, 52 (11), 1751-1763.

Arya, Anil, Brian Mittendorf, and David E.M. Sappington (2007), "The Bright Side of Supplier Encroachment," Marketing Science, 26 (5), 651-659.

B

Baker, William E. (1999), "When can Affective Conditioning and Mere Exposure Directly Influence Brand Choice?" Journal of Advertising, 28 (4), 31-46.

Balasubramanian (1994), "Beyond Advertising and Publicity: Hybrid Messages and Public Policy Issues," Journal of Advertising, 23 (4), 29-46.

Bass, Frank M., and Jerry Wind (1995), "Introduction to the Special Issue: Empirical Generalizations in Marketing," Marketing Science, 14 (3), supplement G1-G5.

Basuroy, Suman, Subimal Chatterjee, and S. Abraham Ravid (2003), "How Critical are Critical Reviews? The Box Office Effects of Film Critics, Star Power, and Budgets," Journal of Marketing, 67 (4), 103-117.

Benartzi, Shlomo, and Richard H. Thaler (1995), "Myopic Loss Aversion and the Equity Premium Puzzle," The Quarterly Journal of Economics, 110 (1), 73 - 92.

Berger, Jonah, Alan T. Sorensen, and Scott J. Rasmussen (2010), “Positive Effects of Negative Publicity: When Negative Reviews Increase Sales," Marketing Science, 29 (5), 815-827.

Bijmolt, Tammo, Harald J. van Heerde, and Rik GM Pieters (2005), "New Empirical Generalizations on the Determinants of Price Elasticity," Journal of Marketing Research, 42 (2), 141-156.

Boatwright, Peter and Joseph C. Nunes (2001), "Reducing Assortment: An Attribute-Based Approach," Journal of Marketing, 65 (3), 50-63.

— and - (2004), Correction note for "Reducing Assortment: An Attribute-Based Approach," Journal of Marketing, 68 (3), iv.

Borle, Sharad, Peter Boatwright, Joseph B. Kadane, Joseph C. Nunes, and Shmuli Galit(2005), "The Effect of Product Assortment Changes on Customer Retention," Marketing Science, 24 (4), 616-622.

Brandhome (2009), "Colruyt Grote Winnaar van Distributieconflict Tussen Delhaize en Unilever [Colruyt Grand Winner of Distribution Conflict between Delhaize and Unilever], February 16, 2009.

Breugelmans, Els, Katia Campo, and Els Gijsbrechts (2006), “Opportunities for Active Stock-Out Management in Online Stores: The Impact of the Stock-Out Policy on Online Stock-Out Reactions," Journal of Retailing, 82 (3), 215-228.

Broniarczyk, Susan M., Wayne D. Hoyer, and Leigh McAlister (1998), "Consumers' Perceptions of the Assortment Offered in a Grocery Category: The Impact of Item Reduction," Journal of Marketing Research, 35 (2), 166-176.

Burroughs, James E. and Aric Rindfleisch (2002), "Materialism and Well-Being: A Conflicting Values Perspective," Journal of Consumer Research, 29 (3), 348-370. 
Campo, Katia, Els Gijsbrechts, and Patricia Nisol (2000), "Towards Understanding Consumer Response to Stock-Outs," Journal of Retailing, 76 (2), 219-242.

Chaney, Paul K., Timothy M. Devinny, and Russell S. Winer (1991), "The Impact of NewProduct Introductions on the Market Value of Firms," Journal of Business, 64 (4), 573-610.

Chen, Yubo, Shankar Ganesan, and Yong Liu (2009), "Does a Firm's Product-Recall Strategy Affect its Financial Value? An Examination of Strategic Alternatives during Product-Harm Crises," Journal of Marketing, 73 (6), 214-226.

Chintagunta, Pradeep K., Vrinda Kadiyali, and Naufel J. Vilcassim (2006), "Endogeneity and Simultaneity in Competitive Pricing and Advertising: A Logit Demand Analysis," Journal of Business, 76 (6), 2761-2787.

Chevalier, Judith A., and Dina Mayzlin. "The Effect of Word of Mouth on Sales: Online Book Reviews," Journal of Marketing Research, 43 (3), 345-354.

Chu, Wujin, and Paul R. Messinger (1998), "Information and Channel Profits," Journal of Retailing, 73 (4), 487-499.

Cleeren, Kathleen, Marnik G. Dekimpe, and Kristiaan Helsen (2008), "Weathering Product-Harm Crises," Journal of the Academy of Marketing Science, 36 (2), 262-270.

_ - Harald J. van Heerde, and Marnik G. Dekimpe (2013), "Rising from the Ashes: How Brands and Categories Can Overcome Product-Harm Crises," Journal of Marketing, 77 (2), 58-77.

Connelly, Brian L., S. Trevis Certo, R. Duane Ireland, and Christopher R. Reutzel (2011), "Signaling Theory: A Review and Assessment," Journal of Management, 37 (1), 39-67.

Contractor, Farok J., Vikas Kumar, and Sumit K. Kundu (2007), "Nature of the Relationship between International Expansion and Performance: The Case of Emerging Market Firms," Journal of World Business, 42 (4), 401-417.

Coughlan, Anne T., Erin Anderson, Louis W. Stern, and Adel I. El-Ansary (2006), Marketing Channels, Pearson Education. Inc, New Jersey, 7th edition.

Cui, Geng, and Hon-Kwong Lui (2005), "Order of Entry and Performance of Multinational Corporations in an Emerging Market: A Contingent Resource Perspective," Journal of International Marketing, 13 (4), 2856.

D

Davidson, Wallace N. and Dan L. Worrell (1992), "The Effect of Product Recall Announcements on Shareholder Wealth," Strategic Management Journal, 13 (6), 467-473.

Dawar, Niraj and Jason Stornelli (2013), "Rebuilding the Relationship between Manufacturers and Retailers," MIT Sloan Management Review, 54 (2), 83-90.

De Morgen (2009), "Financials Gaan Onderuit bij Sluiting Bel20 [Financials Decrease at Closure of Bel20], De Morgen, February 10, 2009.

De Standaard (2009), "Bankaandelen Onderuit in Brussel [Stock Prices Banks Decrease in Brussel]," De Standaard, February 10, 2009.

— (2011), "Prijzenoorlog houdt Disney-poppen uit Fun-winkels [Price-War Keeps Disney-Dolls out of FunStores]," De Standaard, July 14, 2013.

Die Welt (2014), “Getränke: Lidl Scheißt Kultmarke Coca-Cola Raus [Drinks: Lidl Kicks Cult Brand Coca-Cola out of Assortment]," Die Welt, June 20, 2014.

Dinner, Isaac M., Harald J. van Heerde, and Scott A. Neslin (2014), "Driving Online and Offline Sales: The Cross-Channel Effects of Traditional, Online Display, and Paid Search Advertising," Journal of Marketing Research, 51 (5), 527-545.

Distrifood (2005a), “Peijnenburg: AH Dumpt Ontbijtkoek Kapot [Peijnenburg: AH Destroys Breakfast Cake with Low Prices]," Distrifood, February 3, 2005.

- (2005b), "Coca-Cola Slaat Terug in Strijd met Superunie [Coca-Cola Fights Back in Battle with Superunie], Distrifood, June 27, 2005.

- (2005c), "Sprite en Fanta uit het Schap bij Superunie [Sprite and Fanta Delisted at Superunie]," Distrifood, May 31, 2005. 
- (2016), "Jumbo na Hak nu ook in Clinch met Aviko [Jumbo Clashes with Aviko after Fight with Hak]," Distrifood, March 1, 2016.

dpa-AFX (2015), "Lücken im Regal: Real hat Ärger mit Lieferanten [Gaps in the Shelves, Real Fights with Suppliers]," July 17, 2015.

Draganska, Michaela, Daniel Klapper, and Sofia B. Villas-Boas (2010) "A Larger Slice or a Larger Pie? An Empirical Investigation of Bargaining Power in the Distribution Channel," Marketing Science, 29 (1), 5775.

Drèze, Xavier, Stephen J. Hoch, and Mary E. Purk (1994), "Shelf Management and Space Elasticity," Journal of Retailing, 70 (4), 301-326.

Dukes, Anthony J., Esther Gal-Or, and Kannan Srinivasan (2006), "Channel Bargaining with Retailer Asymmetry," Journal of Marketing Research, 43 (1), 84-97.

- Tansev Geylani, and Kannan Srinivasan (2009), "Strategic Assortment Reduction by a Dominant Retailer," Marketing Science, 28 (2), 309-319.

\section{E}

Ebbes, Peter, Dominik Papies, and Harald J. van Heerde (2011), "The Sense and Non-Sense of Holdout Sample Validation in the presence of Endogeneity," Marketing Science, 30 (6), 1115-1122.

Eisend, Martin and Franziska Küster (2011), "The Effectiveness of Publicity versus Advertising: a MetaAnalytic Investigation of Its Moderators," Journal of the Academy Marketing Science, 39 (6), 906-921.

Emmelhainz, Margaret A., James R. Stock, and Larry W. Emmelhainz (1991) "Consumer Responses to Retail Stock-Outs," Journal of Retailing, 67 (2), 138-148.

Erasmus Food Management Institute (2000) “Out-of-Stock, Out-of-Business?" Rotterdam: EFMI.

Erdem, Tülin, and Joffre Swait (1998), "Brand Equity as a Signaling Phenomenon," Journal of Consumer Psychology, 7 (2), 131-157.

- Joffre Swait, and Jordan Louviere (2002), "The Impact of Brand Credibility on Consumer Price Sensitivity," International Journal of Research in Marketing, 19 (1), 1-19.

\section{$\mathbf{F}$}

Fama, Eugene F. (1970), "Efficient Capital Markets: A Review of Theory and Empirical Work," Journal of Finance, 25 (2), 383-417.

Folkes, Valerie S. (1984a), "An Attributional Approach to Postpurchase Conflict Between Buyers and Sellers," in Advances in Consumer Research Volume 11, eds. Thomas C. Kinnear, Provo, UT : Association for Consumer Research, Pages: 500-503.

- (1984b), "Consumer Reactions to Product Failure: An Attributional Approach," Journal of Consumer Research, 10 (4), 398-409.

- (1988), "Recent Attribution Research in Consumer Behavior: A Review and New Directions," Journal of Consumer Research, 14 (4), 548-560.

Frazier, Gary L., and John O. Summers (1984), "Interfirm Influence Strategies and Their Application within Distribution Channels," Journal of Marketing, 48 (3), 43-55.

Freedman, Seth, Melissa Kearney, and Mara Lederman (2012) "Product Recalls, Imperfect Information, and Spillover Effects: Lessons from the Consumer Response to the 2007 Toy Recalls," Review of Economics and Statistics, 94 (2), 499-516.

Frey, Regina-Viola, Tomás Bayón, and Dirk Totzek (2013), “How Customer Satisfaction Affects Employee Satisfaction and Retention in a Professional Services Context," Journal of Service Research, 16 (4), 503517.

\section{G}

Gaski, John F. (1984), "The Theory of Power and Conflict in Channels of Distribution," Journal of Marketing, 48 (3), 9-29.

Gedenk, Karen, Scott A. Neslin, and Kusum L. Ailawadi (2006), "Sales Promotion," in Retailing in the 21st Century, Springer Berlin Heidelberg, 345-359. 
Geyskens, Inge, Katrijn Gielens, and Marnik G. Dekimpe (2002), "The Market Valuation ofInternet Channel Additions," Journal of Marketing, 66 (2), 102-119.

- Jan-Benedict E.M. Steenkamp, and Nirmalya Kumar (1999), "A Meta-Analysis of Satisfaction in Marketing Channel Relationships," Journal of Marketing Research, 36 (2), 223-238.

Geylani, Tansev, Anthony J. Dukes, and Kannan Srinivasan (2007), "Strategic Manufacturer Response to a Dominant Retailer," Marketing Science, 26 (2), 164-178.

Gielens, Katrijn, Linda M. Van de Gucht, Jan-Benedict E.M. Steenkamp, and Marnik G. Dekimpe (2008), "Dancing with a Giant: The Effect of Wal-Mart's Entry into the United Kingdom on the Performance of European Retailers," Journal of Marketing Research, 45 (5), 519-534.

An Investigation Across Products and Countries," International Journal of Marketing Research, 24 (2), 97-111.

Goldberg, Marvin E., and Jon Hartwick (1990), "The Effects of Advertiser Reputation and Extremity of Advertising Claim on Advertising Effectiveness," Journal of Consumer Research, 17 (2), 172-179.

Grover, Rajiv, and V. Srinivasan (1992), "Evaluating the Multiple Effects of Retail Promotions on Brand Loyal and Brand Switching Segments," Journal of Marketing Research, 29 (1), 76-89.

\section{H}

Hair, Joseph F., William C. Black, Barry J. Babin, and Rolph E. Anderson (2010), Multivariate Data Analysis: A Global Perspective, 7th ed. Upper Saddle River, NJ: Pearson/Prentice Hall.

Heider, Fritz (1958), "The Psychology of Interpersonal Relations," New York: Wiley.

Het Financieele Dagblad (2006), “Winstnemingen Trekken Wissel op Mijnbouwers [No More Profit Increases for Mineworkers]," January 6, 2006.

Hingley, Martin K. (2005), "Power to All Friends? Living with Imbalance in Supplier-Retailer Relationships," Industrial Marketing Management, 34 (8), 848-858.

Hsu, Liwu, and Benjamin Lawrence (2016), "The Role of Social Media and Brand Equity during a Product Recall Crisis: A Shareholder Value Perspective," International Journal of Research in Marketing. 33 (1), 59-77.

Huang, Jen-Hung, and Yi-Fen Chen (2006), "Herding in Online Product Choice," Psychology \& Marketing, 23 (5), 413-428.

Huang, Qingyi, Vincent R. Nijs, Karsten Hansen, and Eric T. Anderson (2012), "Wal-Mart's Impact on Supplier Profits," Journal of Marketing Research, 49 (2), 131-143.

Hunt, Shelby D., and John R. Nevin (1974), "Power in a Channel of Distribution: Sources and Consequences," Journal of Marketing Research, 11 (2), 186-193.

\section{J}

Jain, Prem C. (1982), "Cross-Sectional Association between Abnormal Returns and FirmSpecific Variables," Journal of Accounting and Economics, 4, 205-228.

Johnson, Joseph, and Gerard J. Tellis (2008), "Drivers of Success for Market Entry into China and India," Journal of Marketing, 72 (3), 1-13.

Judge, George G., R. Carter Hill, William E. Griffiths, Helmut Lutkepohl, and Tsoung-Chao Lee (1998), Introduction to the Theory and Practice of Econometrics, $2^{\text {nd }}$ edition, Hoboken, New Jersey: John Wiley \& Sons.

K

Kim, Jooyoung, Hye Jin Yoon, and Sun Young Lee (2010), "Integrating Advertising and Publicity," Journal of Advertising, 39 (1), 97-114.

Klein, Jill, and Niraj Dawar (2004), "Corporate Social Responsibility and Consumers' Attributions and Brand Evaluations in a Product-Harm Crisis," International Journal of Research in Marketing, 21 (3), 203-217.

Koza, Karen L. and Rajiv P. Dant (2007), "Effects of Relationship Climate, Control Mechanism, and Communications on Conflict Resolution Behavior and Performance Outcomes," Journal of Retailing, 83 (3), 279-296. 
Kumar, Nirmalya, Lisa K. Scheer, and Jan-Benedict E.M. Steenkamp (1995), "The Effects of Perceived Interdependence on Dealer Attitudes," Journal of Marketing Research, 32 (3), 348-356.

$\mathbf{L}$

Lamey, Lien, Barbara Deleersnyder, Jan-Benedict Steenkamp, and Marnik G. Dekimpe (2014), "Innovation Success: The Overlooked Role of the Retailer," MSI report.

Lebensmittelzeitung (2004), "Süßwaren unter Druck [Confectionary under pressure]," Lebensmittelzeitung, February 5, 2004.

— (2005), "DIY-Brance Liegt Sich in Den Haaren [Clashes in DIY Branche]," Lebensmittelzeitung, January 13, 2005.

- (2007), "Paulaner reagiert auf Auflistung [Paulaner Responds to Delisting],"Lebensmittelzeitung, April 19, 2007.

- (2009), "Zoff Zwischen Metro und Gerolsteiner [Clash Between Metro and Gerolsteiner]," Lebensmittelzeitung, August 13, 2008.

- (2013), "Unilever eckt mit Preiserhöhung an" [Unilever Irritates with Price Increase]," Lebensmittelzeitung, June 6, 2013.

Liu, Yan, and Venkatesh Shankar (2015), "The Dynamic Impact of Product-Harm Crises on Brand Preference and Advertising Effectiveness: An Empirical Analysis of the Automobile Industry," Management Science, 61 (10), 2514-2535.

Liu, Yunchuan, Z. and John Zhang (2006), "Research Note-The Benefits of Personalized Pricing in a Channel," Marketing Science, 25 (1), 97-105.

Lord, Kenneth R. and Sanjay Putrevu (1993), "Advertising and Publicity: An Information Processing Perspective," Journal of Economic Psychology, 14 (1), 57-84.

Lowry, Tina M., Cele C. Otnes, and Julie A. Ruth (2004), "Social Influences on Dyadic Giving over Time: A Taxonomy from the Giver's Perspective," Journal of Consumer Research, 30 (4), 547-558.

Luo, Xueming (2007), "Consumer Negative Voice and Firm-Idiosyncratic Stock Returns," Journal of Marketing, 71 (3), 75-88.

Lusch, Robert F. (1976), "Channel Conflict - It's Impact on Retailer Operating Performance," Journal of Retailing, 52 (2), 3-12 and 89-90.

Lynch, Jr. John G., and Dan Ariely (2000), "Wine Online: Search Costs Affect Competition on Price, Quality, and Distribution," Marketing Science, 19 (1), 83-103.

M

Maehle, Natalia, and Magne Supphellen (2015), "Advertising Strategies for Brand Image Repair: The Effectiveness of Advertising Alliances," Journal of Marketing Communications, 21 (6), 450-462.

Malle, Bertram F., Steve Guglielmo, and Andrew E. Monroe (2014), "A Theory of Blame," Psychological Inquiry, 25 (2), 147-186.

Mazodier, Marc, and Dwight Meruka (2012), "Achieving Brand Loyalty Through Sponsorship: the Role of Fit and Self-Congruity," Journal of the Academy of Marketing Science, 40 (6), 807-820.

McWilliams, Abagail, and Donald Siegel (1997), "Event Studies in Management Research:Theoretical and Empirical Issues," Academy of Management Journal, 40 (3), 626-657.

Messinger, Paul R., Chakravarthi Narasimhan (1995), "How Power Shifted in the Grocery Channel?" Marketing Science, 14 (2), 189-223.

Mohr, Jakki, and Robert Spekman (1994), "Characteristics of Partnership Success:Partnership Attributes, Communication Behavior, and Conflict Resolution Techniques," Strategic Management Journal, 15 (2), 135-152.

$\mathbf{N}$

Nevo, Aviv (2001), "Measuring Market Power in the Ready-To-Eat Cereal Industry," Econometrica, 69 (March), 307-342. 
P

Patell, James M. (1976), “Corporate Forecasts of Earnings per Share and Stock Price Behavior: Empirical Test," Journal of Accounting Research, 14 (2), 246-276.

Peterson, Robin T. (2006), "Improving Relationships with Small Business Buyers," Journal of Marketing Channels, 13 (3), 63-77.

Priester, Joseph, R., and Richard E. Petty (2003), "The Influence of Spokesperson Trustworthiness on Message Elaboration, Attitude Strength, and Advertising Effectiveness,", Journal of Consumer Psychology, 13 (4), 408-421.

$\mathbf{R}$

Raassens, Néomie, Stefan Wuyts, and Inge Geyskens (2012), "The Market Valuation of Outsourcing New Product Development," Journal of Marketing Research, 49 (5), 682-698.

—- Stefan Wuyts, and Inge Geyskens (2014), "The Performance Implications of Outsourcing Customer Support to Service Providers in Emerging versus Established Economies," International Journal of Research in Marketing, 31 (3), 280-292.

Rabe-Hesketh, Sophia, and Anders Skrondal (2008), Multilevel and Longitudianl Modeling using Stata, $2^{\text {nd }}$ edition, Collage Station, Texas: Stata Press.

Reibstein, David J., and Paul W. Farris (1995), "Market Share and Distribution: A Generalization, a Speculation, and Some Implications," Marketing Science, 14 (3), 190-202.

Rooderkerk, Robert P., Harald J. Van Heerde, Tammo H.A. Bijmolt (2013), “Optimizing Retail Assortments," Marketing Science, 32 (5), 699-715.

Rosenberg, Larry J., and Louis W. Stern (1971), "Conflict Measurement in the Distribution Channel," Journal of Marketing Research, 8 (4), 437-442.

\section{S}

Sethuraman, Raj, Gerard J. Tellis, and Richard A. Briesch (2011), "How Well does Advertising Work? Generalizations from Meta-Analysis of Brand Advertising Elasticities," Journal of Marketing Research, 48 (3), 457-471.

Shankar, Venkatesh, Gregory S. Carpenter, and James Farley (2012), Handbook of Marketing Strategy, Cheltenham, UK, Northampton MA: Elward Elgar Publishing.

Skinner, Steven J., Jule B. Gassenheimer, and Scott W. Kelley (1992), "Cooperation in Supplier-Dealer Relations," Journal of Retailing, 68 (2), 174-193.

Sloot, Laurens M., Peter C. Verhoef, and Philip Hans Franses (2005), "The Impact of Brand Equity and the Hedonic level of Products on Consumer Stock-Out Reactions," Journal of Retailing, 81 (1), 15-34.

— , and Peter C. Verhoef (2008), "The Impact of Brand Delisting on Store Switching and Brand Switching Intentions," Journal of Retailing, 84 (3), 281-296.

Smith, Robert E., and Christine A. Vogt (1995), "The Effects of Integrating Advertising and Negative Word-ofMouth Communications on Message Processing and Response," Journal of Consumer Psychology, 4 (2), 133-151.

Song, X. Michael, Jinhong Xie, and Barbara Dyer (2000), "Antecedents and Consequences of Marketing Managers' Conflict Handling Behaviors," Journal of Marketing, 64 (1), $50-66$.

Sood, Ashish, and Gerard J. Tellis (2009), "Do Innovations Really Pay Off? Total Stock Market Returns to Innovation," Marketing Science, 28 (3), 442-456.

Sotgiu, Francesca, and Katrijn Gielens (2015), "Suppliers Caught in Supermarket Price Wars: Victims or Victors? Insights from a Dutch Price War," Journal of Marketing Research, 52 (6), 784-800.

Srinivasan, Shuba and Dominique M. Hanssens (2009), "Marketing and Firm Value: Metrics, Methods, Findings, and Future Directions," Journal of Marketing Research, 46 (3), 293-312.

Srinivasan, Shuba, Koen Pauwels, Dominique M. Hanssens, and Marnik G. Dekimpe (2004), "Do Promotions Benefit Manufacturers, Retailers, or Both?," Management Science, 50 (5), 617-629. 
Stammerjohan, Claire, Charles M. Wood, Yuhmiin Chang, and Esther Thorson (2005), "An Empirical Investigation of the Interaction between Publicity, Advertising, and Previous Brand Attitudes and Knowledge," Journal of Advertising, 34 (4), 55-67.

Stephen, Andrew T. and Jeff Galak (2012), "The Effects of Traditional and Social Earned Media on Sales: A Study of Microlending Marketplace," Journal of Marketing Research, 49 (5), 624-639.

Stuart, Toby E. (2000), "Interorganizational Alliances and the Performance of Firms: A Study of Growth and Innovation Rates in a High-Technology Industry," Strategic Management Journal, 21 (8), 791-811.

\section{T}

Tellis, Gerard J. (1988), "The Price Elasticity of Selective Demand: A Meta-Analysis of Econometric Models of Sales," Journal of Marketing Research, 25 (4), 331-341.

Thain, Greg, and John Bradley (2012), Store Wars: The Worldwide Battle for Mindspace and Shelfspace, Online and In-Store, John Wiley \& Sons, 2012

The Grocer (2011a), "Delistings by Tesco push Premier into Profit Alert," The Grocer, July 1, 2011.

The Grocer (2011b), "Sainsbury's Hit by Pepsi Drought in Cost Hike Row," The Grocer, February 14, 2011.

- (2011c) "Tesco's Premier Cull: the Delisted Products in Full," The Grocer, July 1, 2011.

- (2015), "Tesco Squares up to CCE as it Pulls Schweppes Lines," The Grocer, March 7, 2015.

The Telegraph (2016), "No End in Sight for Falling Shop Prices as Pressure Mounts on Retailers," The Telegraph, June 1, 2016.

Thirumalai, Sriram, and Kingshuk K. Sinha (2011), "Product Recalls in the Medical Device Industry: an Empirical Exploration of the Sources and Financial Consequences," Management Science, 57 (2), 376392.

Tversky, Amos, and Daniel Kahneman (1991), "Loss Aversion in Riskless Choice: A Reference-Dependent Model," The Quarterly Journal of Economics, 106 (4), 1039-1061.

Tybout, Alice M., Bobby J. Calder, and Brian Sternthal (1981), "Using Information Processing Theory to Design Marketing Strategies," Journal of Marketing Research, 73-79.

V

Van der Maelen, Sara, Els Breugelmans, and Kathleen Cleeren (2017), "The Clash of the Titans: On Retailer and Manufacturer Vulnerability in Conflict Delistings," Journal of Marketing, forthcoming.

Van Heerde, Harald J., Els Gijsbrechts, and Koen Pauwels (2008), "Winners and Losers in a Major Price War," Journal of Marketing Research, 45 (5), 499-518.

_- Els Gijsbrechts, and Koen Pauwels (2015), "Fanning the Flames? How Media Coverage of a Price War Affects Retailers, Consumers, and Investors," Journal of Marketing Research, 52 (5), 674-639.

_- Maarten J. Gijsenberg, Marnik G. Dekimpe, and Jan-Benedict E.M. Steenkamp (2013), "Price and Advertising Effectiveness over the Business Cycle," Journal of Marketing Research, 50 (2), 177-193.

- Kristiaan Helsen, and Marnik G. Dekimpe (2007), "The Impact of a Product-Harm Crisis on Marketing Effectiveness," Marketing Science, 26 (2), 230-245.

Verhoef, Peter C., and Laurens M. Sloot (2006), "Out-of-Stock: Reactions, Antecedents, Management Solutions, and a Future Perspective," in: Retailing in the 21st Century. Springer Berlin Heidelberg, 239253.

W

Whetten, David A. (1989), "What Constitutes a Theoretical Contribution?" The Academy of Management Review, 14 (4), 490-95. Woolridge, Jeffrey M. (2002), Econometric Analysis of Cross-Section and Panel Data. Cambridge, MA: MIT Press.

Wyatt, Robert O., and David P. Badger (1984), "How Reviews Affect Film Interest and Evaluation," Association for Education in Journalism Annual Convention, 1-20. 
Appendix 


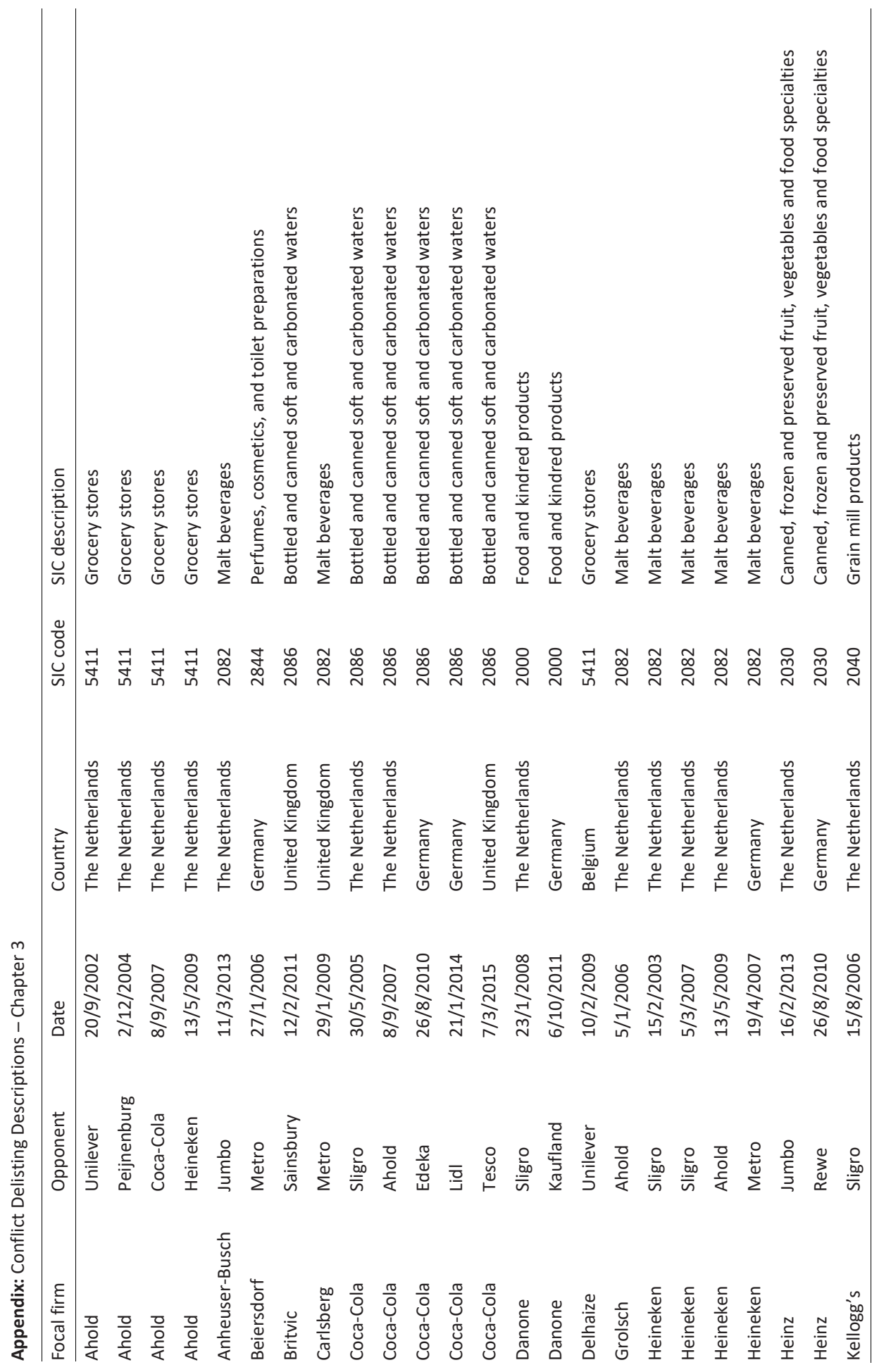




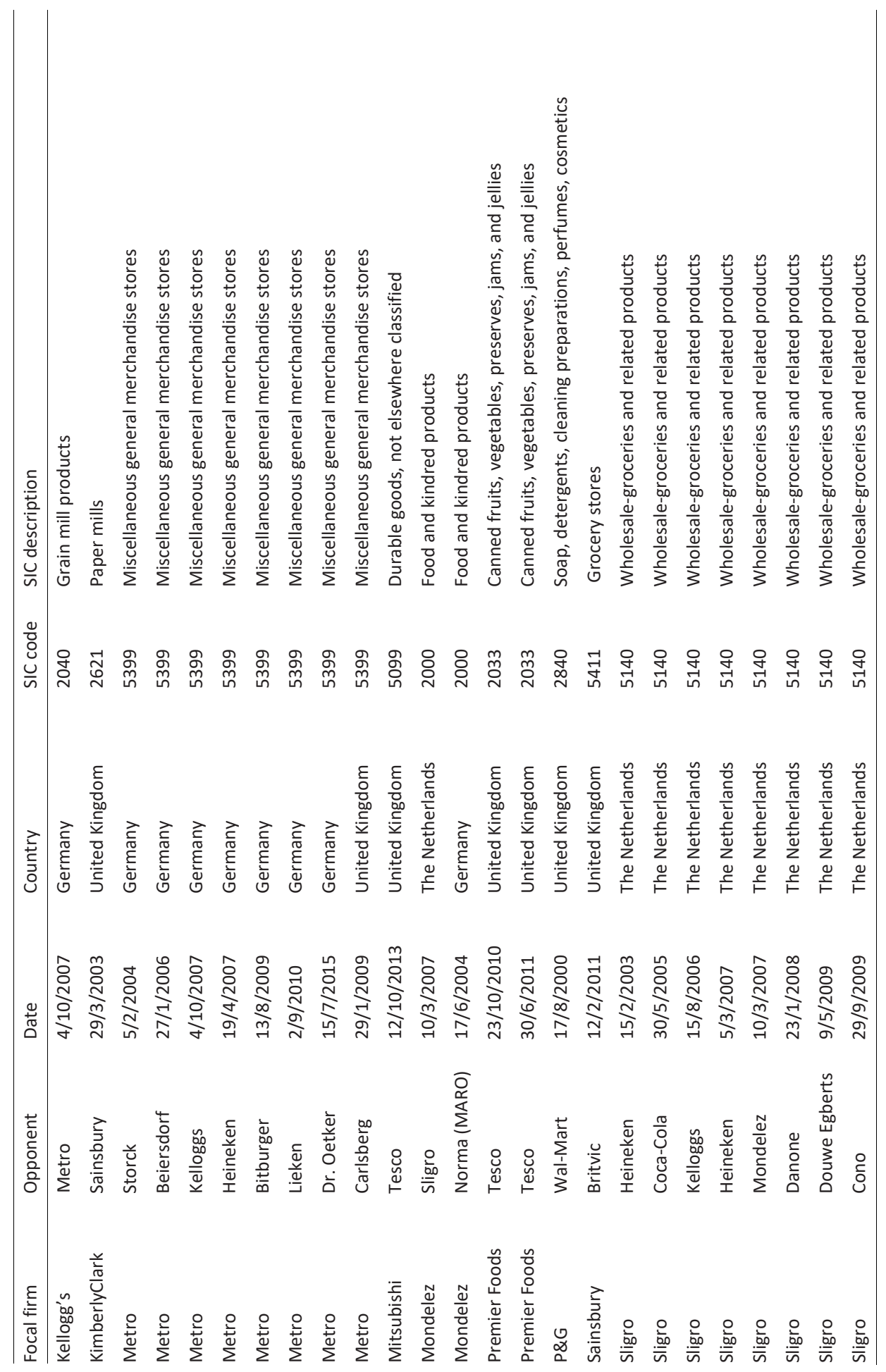



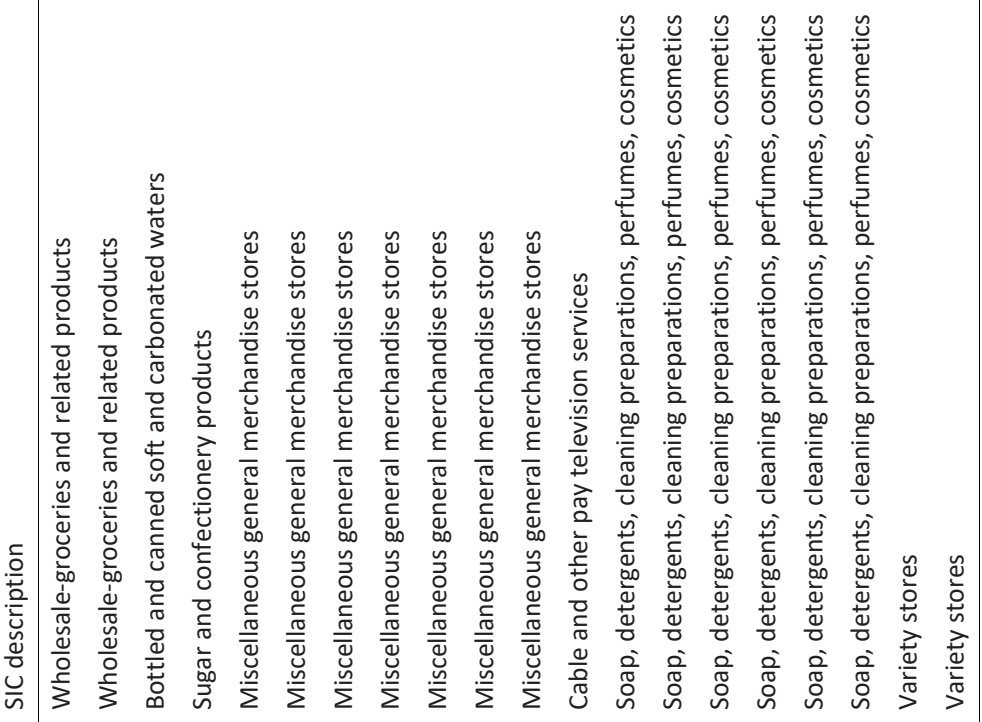

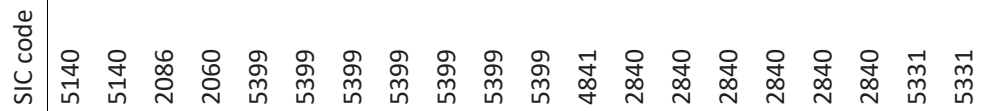

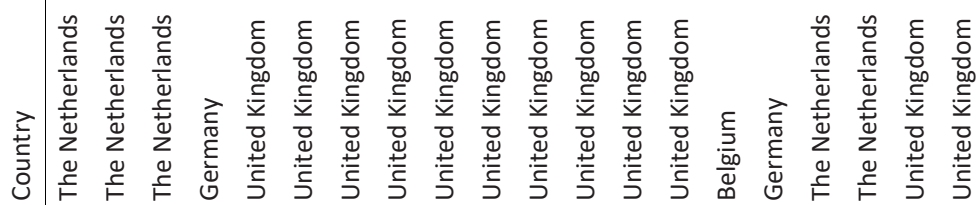

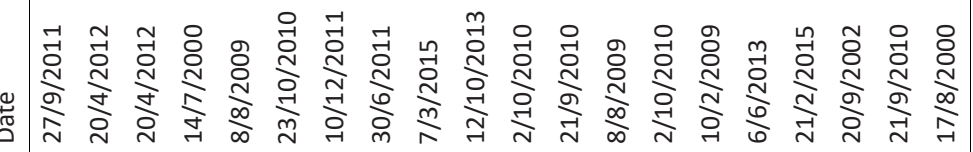

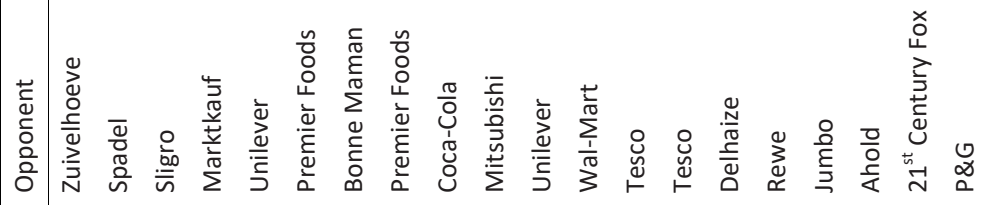

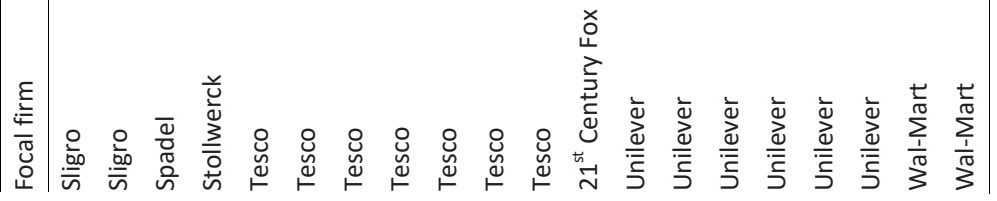


Valorization 

In the following section, I elaborate on the main contributions of this dissertation in terms of their social and economic relevance to society. This process, also known as knowledge valorization, is broadly defined as the "process of creating value from knowledge, by making knowledge suitable and/or available for social (and/or economic) use and by making knowledge suitable for translation into competitive products, services, processes and new commercial activities (Article 23 in the regulation governing the attainment of doctoral degrees, adapted definition based on National Valorization Committee 2011). The social and economic contributions resulting from this dissertation are mainly targeted at manufacturers and retailers facing conflict delisting situations. More specifically, this dissertation provides crucial insights into the consequences of conflict delistings, and thereby facilitating firms' decision making process with regards to conflict delistings (i.e., when is a conflict delisting more or less harmful, and how to respond to a conflict delisting?).

\section{CHAPTER 2: THE EFFECTIVENESS OF MANAGERIAL ACTIONS DURING CONFLICT DELISTINGS}

In Chapter 2, I investigate the appropriate responses to a conflict delisting: how can firms safeguard themselves against the negative consequences? More specifically, I investigate which marketing actions (i.e., price reductions and advertising support) are suitable for which conflict situation (i.e., contingent upon the initiator of the conflict delisting and the amount of publicity surrounding the conflict delisting). As such, both manufacturers and retailers receive tailored recommendations which marketing action(s) to utilize for each specific conflict delisting situation. To facilitate the transfer of knowledge to practitioners, and to help inform marketing decision makers about the appropriate course of action, I developed a marketing dashboard (see Table 2.7 in this dissertation). A marketing dashboard is an efficient tool in which a firms' key performance indicator(s) and its underlying drivers are depicted in a single overview. Firms can use this tool to make accountable marketing decisions, which is especially important given the increasing demands for marketing accountability. The marketing dashboard in Chapter 2 helps practitioners to determine the optimal firm response for a wide array of conflict delisting situations, in an easy-to-use visual overview.

In addition to the academic community, Chapter 2 is therefore of great interest to both manufacturers and retailers. A tailored advice provides them with the necessary tools to assess the situation at hand, and guidance on how to act accordingly to minimize damages done to the company itself, and for the involved consumer. More specifically, the results of this project provide useful guidelines for 1) marketers, 2) purchasing and sales departments, and 3) senior management. First, marketers can determine the appropriate response to a conflict delisting by using the marketing dashboard. Randomly engaging in price reductions or increased advertising support 
can be quite a detrimental strategy, as Chapter 2 reveals that marketing actions work differently in various conflict delisting situations, and might even backfire in some situations. Second, this project gives specific insights into when conflict delistings are more or less severe in terms of sales. This information can assist purchasing and sales departments in their negotiation strategies. When there is no budget available to recover some of the lost sales, they can determine the amount of sales lost in the conflict delisting, which can help them in the decision whether to engage in the conflict delisting in the first place. Finally, it is likely that the purchasing and sales department do not make these choices independently, but rather collaborate with the senior management (e.g., CEO or CMO) in these issues. The right information about the sales consequences of conflict delistings, and the appropriate courses of action in different situations assist senior management to make a solid and well-founded support for their decisions.

In sum, both manufacturers and retailers were clueless how to manage conflict delistings, as managerial actions work differently in conflict situations compared to 'normal' situations in which no conflict delisting occurs. The results of Chapter 2 are therefore crucial, as they provide clear guidelines for manufacturers and retailers on how to respond to a conflict delisting, thereby preventing costly mistakes.

On a more abstract level, the results of Chapter 2 can also be used beyond the manufacturer-retailer dyad, as they provide general insights into how a third party (in this case consumers) reacts to a severe power battle. The results could therefore be applied to a wide variety of real-life conflict situations (e.g., divorce, warfare), in which a third party has to decide who to side with. More specifically, who a third party sides with is contingent upon persuasion techniques and the characteristics of the context the conflict is taking place in.

\section{CHAPTER 3: THE MARKET VALUATION OF CONFLICT DELISTINGS}

In Chapter 3, I investigate how conflict delistings affect total firm performance, in the long run. In addition, I outline the performance implications for a wide array of conflict delistings, providing practitioners clear insights into when conflict delistings are more or less harmful for their firm (i.e., depending on the amount of publicity surrounding the delisting, the number of brands that were delisted, the initiator of the conflict delisting, and the size of the focal and partner firm). For example, it is in a firms' best interest to refrain from eliminating a large range of brands, and to refrain from fighting the power battle via public press. The results can be used to simulate and predict firm performance for a particular conflict delisting situation (see Table 3.6 in the dissertation). Managers can use the simulation analysis to predict what might happen in different conflict delisting scenarios, and act accordingly. 
The results are of great interest for firms that (are about to) face a conflict delisting situation. Also here, the results provide crucial insights for everyone involved in the conflict delisting, including: marketers, purchasing and sales departments, or senior management. In conclusion, in Chapter 3 I provide a much needed first picture on the full impact of a conflict delisting on firm value in different circumstances.

To summarize, this dissertation shows that, overall, conflict delistings have a negative impact on firm performance. However, the direction and magnitude of the effect is contingent upon the specific conflict delisting situation. Firms can use this information to assess the performance implications of conflict delistings. In addition, this dissertation provides a marketing dashboard with clear guidelines for practitioners on how to alleviate these negative consequences. 

Summary 

Due to the rise of powerful retailers, (price) negotiations between manufacturers and retailers often go sour, and result in conflict delistings, where the manufacturers' brands get removed from the retailers' assortment. Despite their frequent occurrence and their potential harmful effects, both academics and practitioners lack information on the performance implications of conflict delistings. This dissertation consists of two empirical chapters that examine the performance implications of conflict delistings, and investigates conditions under which conflict delistings are more or less harmful, albeit from a different perspective.

Chapter 2 takes a consumer perspective to conflict delistings, and focus on the impact of conflict delistings on sales. Conflict delistings can seriously harm manufacturer and retailer sales, due to consumers switching to alternative brands within the store and consumers switching between stores, respectively. I want to unravel which managerial strategies are most suitable in which conflict situation to alleviate these potential losses, and focus on the effectiveness of the manufacturer's as well as the retailer's advertising support and price reductions. I compose a unique and extensive dataset of all conflict delistings that occurred between 2002 and 2012 in four European countries - spanning different categories, manufacturers, and retailers and reveal that both advertising support and price reductions are less effective when faced with a conflict situation that receives a lot of publicity. The results further show that price reductions are an effective marketing tool for the initiator of the conflict, but the initiator should refrain from increasing its advertising spending. For the other party, the effects are reversed: advertising is more effective while price reductions are not advisable. The results of the study thereby provide a marketing dashboard guiding both manufacturers and retailers on which marketing actions are more effective in different types of conflict situations.

Chapter 3 takes an investor perspective, and examines the effect of conflict delistings on total firm value (stock return). Results from an event study show that, on average, conflict delistings severely harm firm value. The direction and magnitude of the stock market reaction is contingent upon the seriousness of the delisting and the capacity to withstand its negative consequences. When the conflict delisting is more serious (i.e., when more brands are delisted and the conflict delisting is heavily publicized), conflict delistings negatively influence firm value. If a firm has the capacity to withstand its negative consequences (i.e., when the firm is the initiator or is larger), firm value is less negatively affected. 



\section{Curriculum Vitae}

Marleen Hermans was born in Venlo, The Netherlands, on October 17, 1985. She received her high school diploma from Blariacum College in Blerick in 2004, and subsequently started her Bachelor degree at Tilburg University. In 2007, Marleen received her B.Sc. degree in International Business at Tilburg University. During her third year, she spent a semester as an exchange student in Århus, Denmark. Upon obtaining her B.Sc. degree, Marleen continued her education at Tilburg University where she obtained both a M.Sc. in Marketing Management (2009) and a Research Master degree in Business (2010, with distinction) with a strong focus on marketing modeling. Afterwards, Marleen worked for approximately two years as a market researcher and project manager at a research market agency in The Netherlands.

In September 2012, Marleen accepted a position as PhD candidate at the Marketing and Supply Chain Department of Maastricht University. Under supervision of Prof. Dr. Ko de Ruyter, Dr. Kathleen Cleeren, and Dr. Néomie Raassens, she applied advanced econometric and statistical methods to guide managerial decision-making. In her dissertation, she focuses on manufacturer-retailer power battles and the consumer and investor responses it brings about. In particular, she investigates which managerial actions (i.e., price and advertising) manufacturers and retailers can take in various conflict situations to mitigate potential losses. Further, she examines the effect of conflict delistings on firm value (stock return). Marleen has presented her research at various international conferences, such as Marketing Science, EMAC, and the EMAC Doctoral Colloquium. In 2015, Marleen was awarded the prestigious AMA Sheth Consortium Fellowship.

Marleen's teaching experience includes coordinating and teaching courses both at the Bachelor and Master level, the supervision of MARBLE projects, and the supervision of master thesis students. She also served as a project manager for Maastricht University's honors program PREMIUM. In addition, in 2016, she obtained her University Teaching Qualification (BKO). 


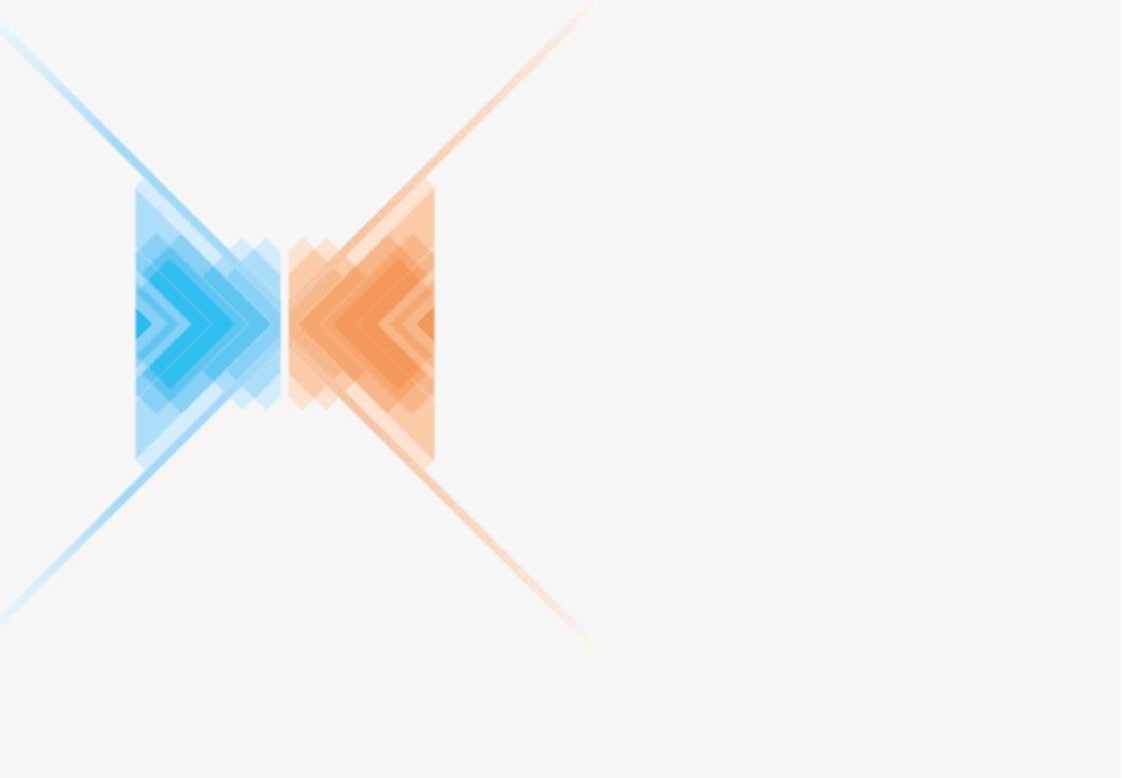

